\section{TA7 \\ 1034 \\ กo. GL \\ $84-2$ \\ COP. 2 \\ US Army Corps \\ of Engineers}

US-CM-Cinerty of the Uniled States Government

TECHNICAL REPORT GL-84-2

\title{
EVALUATION OF PROPERTIES OF RECYCLED ASPHALT CONCRETE HOT MIX
}

\author{
by \\ Elton R. Brown \\ Geotechnical Laboratory \\ U. S. Army Engineer Waterways Experiment Station \\ P. O. Box 631, Vicksburg, Miss. 39180
}

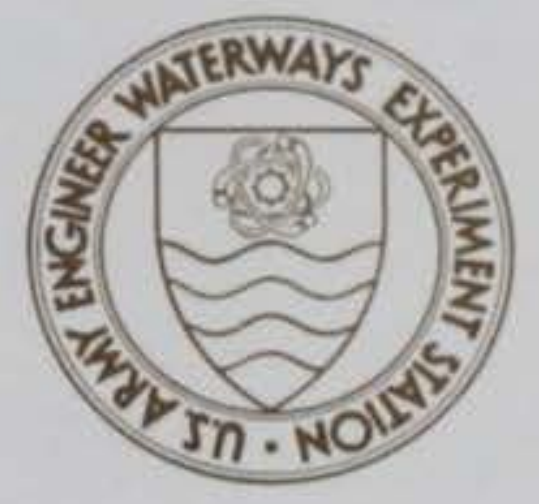

February 1984

Final Report

Approved for Public Release: Distribution Unlimited

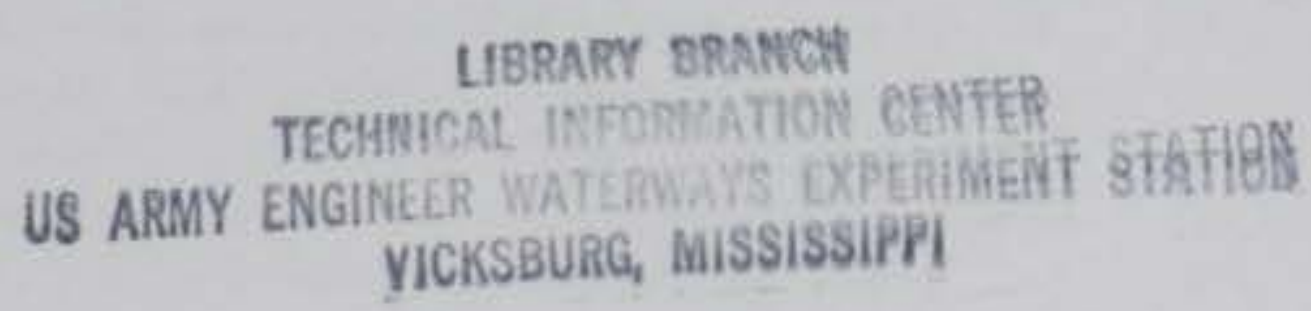

Prepared for Office, Chief of Engineers, U. S. Army

Washington, D. C. 20314

Under Project 4A762719AT40

Work Unit EO/008 
Destroy this report when no longer needed. Do not return it to the originator.

The findings in this report are not to be construed as an official Department of the Army position unless so designated by other authorized documents.

The contents of this report are not to be used for advertising, publication, or promotional purposes. Citation of trade names does not constitute an official endorsement or approval of the use of such commercial products.

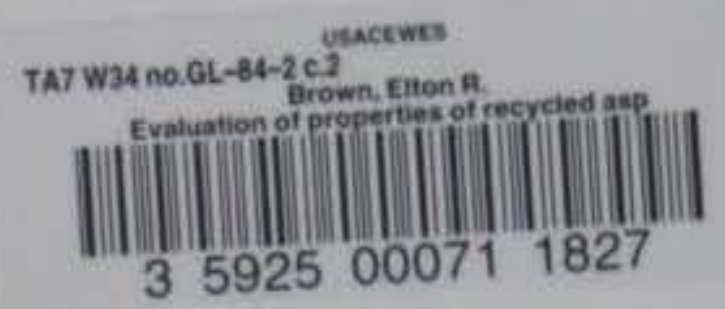


Unclassified

SECURITY CLASSIFICATION OF THIS PAGE (Whon Date Entered)

\begin{tabular}{|c|c|}
\hline REPORT DOCUMENTATION PAGE & $\begin{array}{c}\text { READ INSTRUCTIONS } \\
\text { BEFORE COMPLETING FORM }\end{array}$ \\
\hline $\begin{array}{l}\text { 1. REPORT NUMBER } \\
\text { Technical Report GL-84-2 }\end{array}$ & 3. RECIPIENT'S CATALOG NUMBEA \\
\hline \multirow{2}{*}{$\begin{array}{l}\text { 4. TITLE (and Subtue) } \\
\text { EVALUATION OF PROPERTIES OF RECYCLED } \\
\text { ASPHALT CONCRETE HOT MIX }\end{array}$} & $\begin{array}{l}\text { 5. TYPE OF REPORT A PERIOD COVERED } \\
\text { Final report }\end{array}$ \\
\hline & 6. PERFORMING ORG. REPORT NUMBER \\
\hline $\begin{array}{l}\text { 7. AUTHOR(n) } \\
\text { Elton R. Brown }\end{array}$ & 8. CONTRACT OR GRANT NUMBER(*) \\
\hline $\begin{array}{l}\text { 9. PERFORMING ORGANIZATION NAME AND ADDRESS } \\
\text { U. S. Army Engineer Waterways Experiment Station } \\
\text { Geotechnical Laboratory } \\
\text { P. 0. Box } 631 \text {, Vicksburg, Miss. } 39180\end{array}$ & $\begin{array}{l}\text { 10. PAOGAAM ELEMENT, PROJECT, TASK } \\
\text { AREA OWORK UNIT NUMBERS } \\
\text { Project } 4 \text { A762719AT40, } \\
\text { Work Unit EO/008 }\end{array}$ \\
\hline \multirow{2}{*}{$\begin{array}{l}\text { 11. CONTROLLING OFFICE NAME AND ADDRESS } \\
\text { Office, Chief of Engineers, U. S. Army } \\
\text { Washington, D. C. } 20314\end{array}$} & $\begin{array}{l}\text { 12. REPORT DATE } \\
\text { February } 1984\end{array}$ \\
\hline & $\begin{array}{l}\text { 13. NUMAER OF PAGES } \\
138\end{array}$ \\
\hline \multirow{2}{*}{ 14. MONITOAING AGENCY NAME A ADORESS(if dilforent from Controllina OIfice) } & $\begin{array}{l}\text { 15. SECURITY CLASS. (of this report) } \\
\text { Unclassified }\end{array}$ \\
\hline & $\begin{array}{l}\text { 15a. DECLASSIFICATION/DOWNGRADING } \\
\text { SCHEOULE }\end{array}$ \\
\hline
\end{tabular}

Approved for public release; distribution unlimited.

17. DISTRIBUTION STATEMENT (of the abstract entered In Block 20, If different from Report)

18. SUPPLEMENTARY NOTES

Available from National Technical Information Service, 5285 Port Royal Road, Springfield, Va. 22161

19. KEY WORDS (Continue on reverwe side if necessary and ldentily by block number)

Concrete mixtures Recycled concrete

Concrete properties Rigid pavements

Flexible pavements

Hot mix

20. ABSTAACT (Cantimus ea reverse sits $\|$ neceosary and identity by block number)

Recycling of aged asphalt concrete pavements has been demonstrated to be cost-effective and to reduce the demand for natural resources such as aggregate and asphalt. Because of the advantages derived when using recycled materials, the capability to predict long-term performance is needed so that optimum benefits can be obtained. This study was undertaken to evaluate the laboratory performance of recycled asphalt concrete mixtures and to compare

(Continued)

DD, FORM 1473 EDITION OF, NOV 65 IS OBSOLETE

Unclassified

SECURITY CLASSIFICATION OF THIS PACE (WTran Dato Entered) 
20. ABSTRACT (Continued).

these results to those measured for conventional asphalt concrete mixtures.

To make these comparisons, samples of aged asphalt concrete were obtained from three locations where recycling was planned. These samples were blended with new aggregate and new asphalt materials to produce six different recycled mixtures.

Two aggregate types, a crushed gravel and a crushed limestone, were used to produce two conventional mixtures and to blend with the reclaimed asphalt pavement to produce the six recycled mixtures. Three asphalt materials which were obtained to produce the various mixtures being evaluated consisted of $\mathrm{AC}-20$ for preparing the conventional mixtures and $\mathrm{AC}-5$ and a recycling agent for preparing the recycled mixtures.

The first step in preparing the recycled mixtures was selecting the aggregate type that compared most favorably with the aggregate in the reclaimed asphalt pavement. Recycled mixtures were then prepared using the $\mathrm{AC}-5$ in three mixtures and the recycling agent in three mixtures, resulting in eight mixtures for evaluation (six recycled and two conventional mixtures).

The relative durability, low temperature, water susceptibility, and fatigue properties were evaluated for all mixtures. Tests were conducted on the asphalt binder (combined binder for recycled mixtures) prior to mixing with aggregate and after being recovered from the mixtures used to evaluate fatigue properties. These tests on the binder included penetration at $40^{\circ} \mathrm{F}$ and $77^{\circ} \mathrm{F}$; ductility at $40^{\circ} \mathrm{F}$ and $77^{\circ} \mathrm{F}$; softening point; viscosity at $275^{\circ} \mathrm{F}$, $225^{\circ} \mathrm{F}$, and $140^{\circ} \mathrm{F}$; specific gravity; and rolling thin-film oven test. Tests conducted on the asphalt concrete consisted of Marshall stability at $140^{\circ} \mathrm{F}$, indirect tensile test at $40^{\circ} \mathrm{F}$ and $77^{\circ} \mathrm{F}$, resilient modulus at $40^{\circ} \mathrm{F}$ and $77^{\circ} \mathrm{F}$, flexural fatigue test at $40^{\circ} \mathrm{F}$ and $77^{\circ} \mathrm{F}$, and water susceptibility test.

The Shell BISAR computer program was used to predict the stresses and strains for two typical pavement sections under a given loading condition. Computed stresses and strains were then analyzed along with the laboratory fatigue tests to predict the fatigue performance of the various mixtures.

Results of this study indicated a satisfactory comparison between laboratory performance of recycled mixtures and conventional mixtures. Fatigue analysis indicated that conventional mixtures would provide the greatest fatigue resistance in thick asphalt concrete layers at lower temperatures, while the recycled mixtures would provide the greatest fatigue resistance in thin asphalt layers at higher temperatures. Water susceptibility was shown to be related more to aggregate type than to mixture type. The data show that recycled mixtures prepared with the recycling agent produced mixtures with the lowest durability and poorest low temperature performance when compared with the recycled mixtures prepared with $\mathrm{AC}-5$ or compared with the conventional mixtures. 
This study was conducted by the Geotechnical Laboratory (GL), U. S. Army Engineer Waterways Experiment Station (WES), Vicksburg, Miss., for the Office, Chief of Engineers (OCE), U. S. Army, under Project 4A762719AT40, Work Unit E0/008. Mr. Edward Dudka (OCE) was the Technical Monitor. The work was performed from October 1979 until September 1982. This report describes the results obtained from the project entitled "Recycling Existing Pavement Materials for Pavement Rehabilitation."

WES personnel actively engaged in the conduct of this project included Messrs. A. H. Joseph, J. W. Hall, and Dr. T. D. White, Pavement Systems Division (PSD), GL. The work was conducted under the general supervision of Dr. White, Chief, PSD, GL, and Dr. William F. Marcuson III, Chief, GL. PSD personnel engaged in the testing and analysis of this project included Messrs. Rogers T. Graham, Patrick S. McCaffrey, Jr., David P. Reed, Joey K. Simmons, and Dr. E. R. Brown. This report was written by Dr. Brown.

COL Tilford C. Creel, CE, was Commander and Director of WES during this investigation and the preparation of this report. Mr. Fred R. Brown was Technical Director. 
PREFACE

CONVERSION FACTORS, U. S. CUSTOMARY TO METRIC (SI) UNITS OF

MEASUREMENT

PART I:

INTRODUCTION

Background

Objectives of this Study

Scope of Work

PART II: LITERATURE SURVEY . . . . . . . . . 9

Hot Mix Recycling

Asphalt Durability . . . . . . . 14

Low Temperature Performance . . . . . . . . . . . . 15

Water Susceptibility ............. . . . . 17

Fatigue . . . . . . . . . . . 18

Layered Elastic Analysis . . . . . . . . . . . . . . 23

PART III: PLAN OF EXPERIMENT . . . . . . . . . . . . . . . . . 24

PART IV: DESCRIPTION OF TESTS . . . . . . . . . . . . . . 28

Mix Designs . . . . . . . . . . . . . . . . . 28

Asphalt Binder Tests . . . . . . . . . . . . . 28

Asphalt Mix Tests . . . . . . . . . . . . . . . 29

PART V: TEST RESULTS . . . . . . . . . . . . . . 36

Properties of Reclaimed Asphalt Pavement . . . . . . . . . 36

Mix Design . . . . . . . . . . . . . 36

Evaluation of Asphalt Cement for Each Mixture . . . . . . . . 43

Asphalt Mixture Test Results . . . . . . . . . . . . . 47

PART VI: DISCUSSION OF RESULTS . . . . . . . . . . . . . . 90

Durability . . . . . . . . . . . . . . . . . . 90

Low Temperature Cracking . . . . . . . . . . . . . . 91

Water Susceptibility Results . . . . . . . . . . . . . 95

Analysis of Fatigue . . . . . . . . . . . . . . . 100

Development of a Model to Predict Fatigue Performance . . . . 104

Layered Elastic Analysis of Fatigue Data . . . . . . . . . 107

PART VII : CONCLUSIONS ..................... 126

PART VIII: RECOMMENDATIONS .................... 128

REFERENCES . . . . . . . . . . . . . . . . . . . . . . 130

APPENDIX A: DATA FROM FATIGUE TESTS ................ A1 
U. S. customary units of measurement used in this report can be converted to metric (SI) units as follows:

\section{Multiply}

Fahrenheit degrees

inches

kips (force) per square inch pounds (force) per square inch pounds (mass)

$\begin{array}{cll}\text { By } & & \text { To Obtain } \\ 5 / 9 & & \text { Celsius degrees or Kelvins* } \\ 2.54 & \text { centimetres } \\ 6.894757 & \text { kilograms } \\ 6894.757 & \text { pascals } \\ 0.4535924 & \text { kilograms }\end{array}$

* To obtain Celsius (C) temperature readings from Fahrenheit (F) readings, use the following formula: $C=(5 / 9)(F-32)$. To obtain Kelvin (K) readings, use: $K=(5 / 9)(F-32)+273.15$. 


\section{EVALUATION OF PROPERTIES OF RECYCLED \\ ASPHALT CONCRETE HOT MIX}

\section{PART I: INTRODUCTION}

\section{Background}

Since asphalt pavement recycling became popular in the mid 1970 's, the pavement recycling industry has grown tremendously. Because the price of asphalt binder and high-quality aggregate has continued to rise in recent years, recycling which makes use of existing in place materials has become an economical approach to pavement rehabilitation.

Pavement recycling is generally subdivided into three main categories $(22): *$

1. Surface recycling.

2. Cold recycling.

3. Hot recycling.

Surface recycling which modifies the surface of an existing asphalt concrete pavement includes such processes as rejuvenating, cold milling, and heater-planing-scarifying. Rejuvenating is a process which consists of spraying an asphalt surface with a material that penetrates into the asphalt concrete and improves the properties of the asphalt binder by increasing the penetration and decreasing the viscosity of the binder.

Cold milling has been used as one phase of all three recycling processes. One form of surface recycling consists of milling an existing slick surface to improve the surface texture, thus improving skid resistance. The material removed from the surface can be used to produce recycled cold mix or recycled hot mix. The cold milling machine is also used to reclaim deteriorated asphalt concrete pavements for use in cold and hot recycling projects.

Heater-planing involves heating the surface of an existing asphalt concrete pavement and planing it to a desired grade. Some heater-planers

* Numerals in parentheses refer to corresponding items in the References section at the end of the main text. 
use open flames to heat the existing pavement, while others use indirect heat. After the pavement surface is heated, a grader is generally used to remove the desired thickness of material from the surface. Usually one pass with the heater and grader can remove $1 / 4$ to $1 / 2$ in.* (6.4 to $12.8 \mathrm{~mm}$ ) of material. The heater-planer has traditionally been used to plane roads and airfield pavements to a desired grade prior to an overlay to minimize the overall average thickness of the overlay, but the cold milling machine is now generally used in place of the heater-planer since it provides better grade. control and causes fewer air quality problems.

Heater scarification involves heating the surface of a pavement and scarifying to a depth of approximately $3 / 4 \mathrm{in.}(19.0 \mathrm{~mm})$ and is generally used in conjunction with an overlay to minimize the number and severity of reflective cracks. A rejuvenator or an asphalt emulsion is usually added to the scarified material, and the material is compacted prior to or immediately following the addition of an overlay.

Cold recycling which can be performed in place or at a central plant consists of pulverizing and sizing portions of an existing pavement generally with a cold milling machine, adding a binder, then mixing, placing, and compacting. For design purposes, the cold recycled mixture is usually considered equal in quality to asphalt-stabilized base course.

In hot recycling an existing asphalt concrete pavement is removed, mixed with new aggregate and asphalt cement and/or recycling agent, and then placed and compacted to form a high-quality asphalt concrete. Recycled hot mix is produced at a central plant and is generally considered equal in quality to conventional dense-graded asphalt concrete.

This study is limited to the testing and evaluation of hot recycled mixtures. Since hot mix recycling has only become popular since the mid 1970 's, actual field performance data are limited; therefore, a need exists to develop the capability to predict the performance of these hot recycled mixtures. Little and Epps have shown that, structurally, recycled mixtures are equal to conventional mixtures (49). Though their work did not cover all aspects of performance, initial information

* A table of factors for converting U. S. customary units of measurement to metric (SI) units is presented on page 3 . 
indicates recycled mixtures to be structurally equal to conventional mixtures. Other limited laboratory testing programs $(35,50,66,67)$ have been conducted to determine the durability, water susceptibility, low temperature, and fatigue properties of recycled mixtures. Recycled mixtures have been tested favorably for these properties, but more detailed information concerning these and other properties of recycled mixtures is needed.

Several terms used throughout this study need to be identified at this point. "Reclaimed asphalt pavement" (RAP) refers to the existing asphalt mixture that is removed and mixed with new aggregates and new asphalt binder to form the recycled mixture. "Recycled mixture" describes the hot mixture that is obtained by mixing RAP, new aggregate, and new asphalt binder. "Conventional mixture" describes the hot mixture obtained by mixing new aggregate and new asphalt cement.

\section{Objectives of this Study}

This study was conducted to evaluate the fatigue resistance, durability, low temperature properties, and water susceptibility of recycled asphalt mixtures. The specific objectives of this study include:

1. The evaluation of the durability, water susceptibility, low temperature, and fatigue resistance properties of recycled and conventional mixtures.

2. The extension of the laboratory data and data from the BISAR layered elastic computer program to predict relative performance of two typical pavement sections using recycled and conventional mixtures.

\section{Scope of Work}

To satisfy the objectives of this study, an experiment was designed to prepare and test six recycled asphalt concrete mixtures and two conventional mixtures (Fig. 1). Samples of old asphalt pavements for preparing these recycled mixtures were obtained from three locations. Two new aggregates, two asphalt binders, and a recycling agent were also obtained for preparing the conventional and recycled mixtures.

Mixtures were prepared and tested for Marshall stability, resilient 


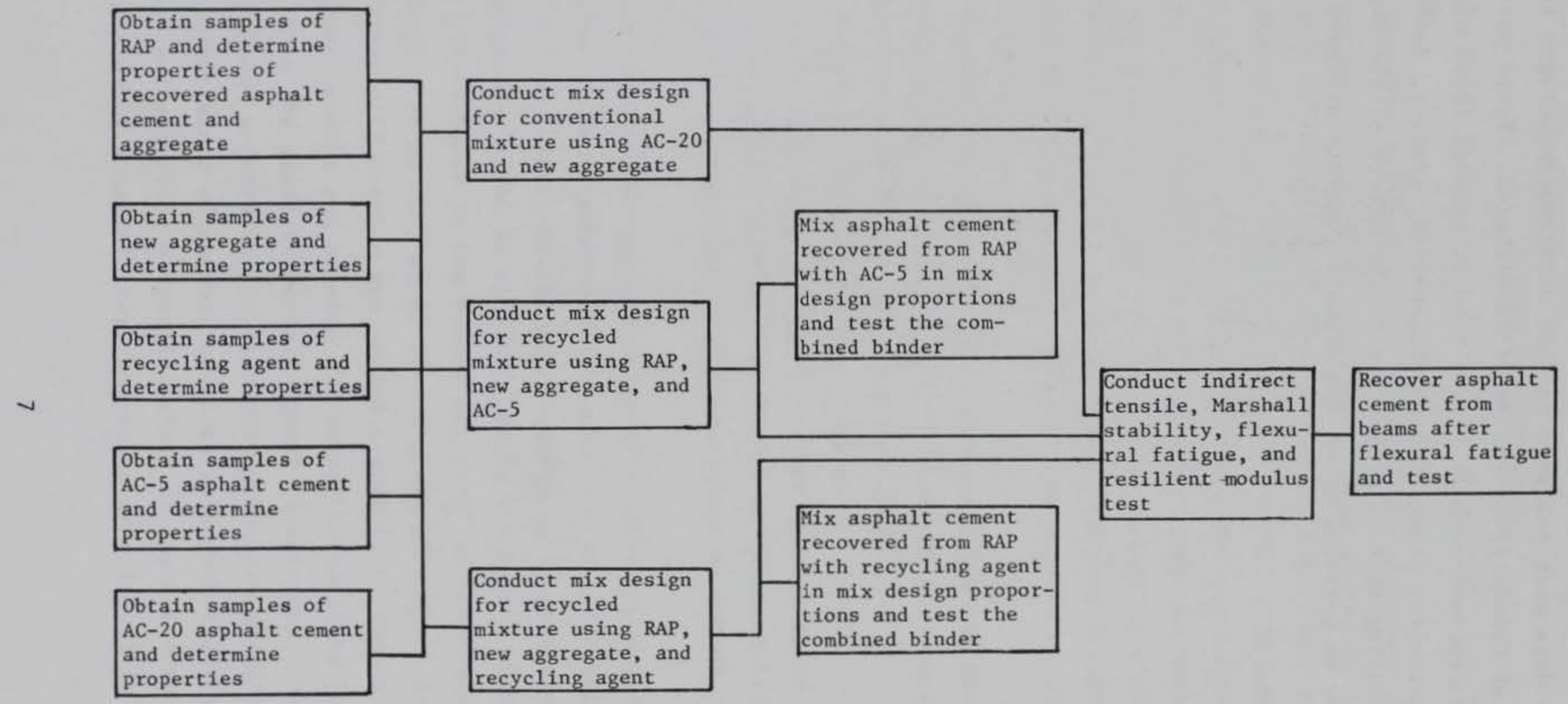

FIG. 1.--General Flow Diagram for Testing of Asphalt Mixtures and Binders Prepared with Materials from Each of the Three RAP Locations 
modulus, indirect tensile strength, water susceptibility, and fatigue resistance. The data were analyzed to show differences between laboratory properties of conventional and recycled mixtures. Tests were conducted on the combined asphalt binder used to produce these mixtures to determine penetration, softening point, specific gravity, ductility, viscosity, and rolling thin-film oven test. The effect of the asphalt binder properties on performance of the asphalt concrete mixtures was determined. 


\section{Hot Mix Recycling}

\section{$\underline{\text { Mix Design }}$}

The Marshall procedure (26) and the Hveem procedure (16) are commonly used to design hot mix asphalt concrete. Many states in the western United States use the Hveem design procedure; most other states use the Marshall procedure. In addition, the Federal Aviation Administration (FAA) and military services use the Marshall design procedure.

The mix design procedures that have been used to design recycled mixtures are similar to procedures used for designing conventional mixtures; however, additional testing is required when designing recycled asphalt concrete mixtures to ensure that the properties of the combined asphalt binder are satisfactory.

The Marshall design procedure discussed below was used in conducting all mix designs for this study. This mix design procedure for conventional mixtures consists of the following steps:

1. Select satisfactory asphalt cement.

2. Select satisfactory aggregate type and aggregate gradation.

3. Select proper asphalt content for anticipated traffic.

4. Evaluate properties of design mixture to ensure minimum requirements are met.

The asphalt cement type is selected to provide satisfactory performance in the climatic conditions in which use is anticipated. For example, the Southwest, which experiences high temperatures during the summer, might use an $\mathrm{AC}-20$ or $\mathrm{AC}-40$, while the North, which experiences moderate temperatures in the summer but very low temperatures in the winter, might use an $\mathrm{AC}-5$ or $\mathrm{AC}-10$. A grade of asphalt cement is selected that will provide the needed stability to the asphalt concrete in the summer months and provide the needed flexibility in the winter months. Once the grade of asphalt cement is selected, the properties for that particular penetration or viscosity grade are specified $(4,13)$. The past performance of asphalt mixtures in a particular area is the best guide for selecting a specific grade of asphalt cement.

Selection of a satisfactory aggregate is critical in obtaining 
satisfactory performance of an asphalt concrete mix. Aggregate specifications, which vary considerably from state to state and within the Federal Government, generally include requirements for gradation, Los Angeles abrasion, crushed faces, flat and elongated count, and soundness test (26). The best procedure for evaluating potential performance of aggregate is to investigate the past in-service performance of the aggregate type under similar loading conditions and climate.

The optimum asphalt content is selected to provide asphalt mixture properties which will ensure satisfactory performance. Two efforts of compaction have been established to produce a density in the laboratory equal to field density after traffic. It has been shown that the 50-blow compactive effort produces a density similar to field densities under traffic with low-pressure tires (28), while the 75-blow compactive effort produces a density similar to field densities under traffic with highpressure tires $(19,27)$.

After a compactive effort has been determined, samples are prepared at various asphalt contents starting on the low side of optimum and ranging up to the high side of optimum. Properties of the asphalt mixtures such as unit weight, stability, flow, voids in the total mixture, and voids filled with asphalt are used to evaluate the mixture quality at each asphalt content and to select the optimum asphalt content. The mix design is determined to select an asphalt content that provides sufficient stability of the mixture in the high summer temperatures and flexibility of the mixture in the low winter temperatures.

The same mix design procedures discussed above are used with recycled mixtures; however, additional tests must be conducted to measure the properties of the combined asphalt binder (21). This procedure involves recovering the asphalt binder from the asphalt mixture $(6,7)$ and testing this recovered asphalt binder for consistency. The penetration (5) and viscosity (3) tests are useful in determining the consistency and quality of asphalt binders. Depending on the consistency of the asphalt binder in the existing pavement, the proper asphalt cement and/or recycling agent is selected as an additive to provide satisfactory mix properties and asphalt binder properties in the designed recycled mixture.

The Hveem method of mix design has the same requirements for asphalt 
cement type and aggregate quality as the Marshall design method. This mix design procedure also has a requirement for voids in the mixture similar to the Marshall design procedure requirements. Two major differences between the Marshall and Hveem mix design procedures are the method specified for compacting samples and the method of measuring stability

$(8,25)$. The Hveem method specifies a kneading compactor for compaction, while the Marshall procedure specifies an impact compactor. Stability measured by the Marshall method is a measure of load required to cause failure of a sample, whereas stability measured by the Heem method is a measure of response to a given nondestructive load. Both methods of mix design should result in selection of similar optimum asphalt contents. The additional tests to ensure satisfactory combined asphalt properties in a recycled mixture are the same for the Hveem and Marshall design procedures.

\section{Construction}

Since the mid 1970 's, the construction of hot mix recycled asphalt concrete pavements has been well documented. The Federal Highway Administration has sponsored a number of demonstration projects in various states that have provided a wealth of knowledge on hot mix recycling (18, $31,40,41,48,62,70)$. Many other agencies have sponsored construction projects that have provided published data.

The drum mixer and batch plants have generally been used to produce recycled hot mix (15). The drum mixer mixes the reclaimed asphalt pavement, new aggregate, and new asphalt cement and/or recycling agent in a drum to produce the recycled mixture. New aggregate which is added at the high end of the drum prevents the flame from coming in direct contact with the RAP. The RAP is added near the midpoint of the drum followed by the addition of the recycling agent, if used, and the new asphalt cement.

Another type of drum mix plant that is used for hot mix recycling is the drum-in-a-drum plant. In this plant, the new aggregate and RAP are added at the high end of the drum; however, the new aggregate enters an inner drum through which the flame is fired while the RAP enters into the outer drum and does not come in contact with the flame. The new asphalt cement or recycling agent is then added at approximately the midpoint of the drum.

Drum mixers have been used successfully to produce many tons of 
recycled hot mix for roads and airfields. Some problems that have occurred include the emission of blue smoke from the stack and the development of small chunks of the RAP that were not broken up completely in the mixing process causing some minor tearing of the mat surface during placement. These problems have been minor, not significantly affecting the quality of mixture, and have been solved with little difficulty.

Batch plants have been modified and used on a number of jobs to satisfactorily produce recycled hot $\operatorname{mix}(15,20,22)$. This process of producing recycled mixtures inside a batch plant is sometimes referred to as the Maplewood or Minnesota process (42). The modification of the batch plants usually consists of adding a hopper to store the RAP, adding a belt to feed the RAP into the weigh bin of the plant, constructing an opening in the side of the plant to feed the RAP into the weigh bin, and adding controls in the plant control room to regulate the amount of RAP added to each batch. In this process, the new aggregate after being heated in the dryer to $500-600^{\circ} \mathrm{F}$ comes in contact with the RAP, new asphalt cement, and recycling agent (if used) in the pugmill and transmits its heat to the other materials. The new asphalt cement is generally heated to approximately $300^{\circ} \mathrm{F}$ prior to mixing, resulting in a mixture temperature of $260-290^{\circ} \mathrm{F}$ as needed. The problems that occur when producing recycled mixture in a batch plant are similar to those that occur with a drum mixer; however, the amount of blue smoke emitted from a batch plant is usually less than that emitted from a drum mixer.

The amount of RAP that can be used in a recycled mixture is limited by the type of plant being used and the quality of the materials being recycled. The drum mixer can produce recycled mixtures with up to 100 percent RAP; however, because of air quality problems, use of 100 percent RAP is not practical. To properly modify the properties of the RAP, a significant amount of new asphalt cement and/or recycling agent and new aggregate usually must be added to the recycled mixture. This requirement limits the amount of RAP that can be incorporated into a recycled mixture to a practical upper limit of 60 percent.

When a batch plant is used to produce recycled mixture, the amount of RAP is limited to approximately 50 percent which requires the new aggregate to be heated to approximately $600^{\circ} \mathrm{F}$ to produce a recycled mixture at the desired temperature. When more than 50 percent RAP is used, 
the aggregate must be heated even higher, increasing the possibility of damage to the dryer and other plant components from the higher temperatures.

Properties of Recycled Mixtures

Hot recycled mixtures designed by various mix design procedures have been tested by laboratories throughout the United States to determine fatigue resistance, water susceptibility, creep, indirect tensile strength, resilient modulus, Marshall stability, and Hveem stability. To date, most of these test results obtained from testing recycled mixtures have compared favorably with conventional mixtures. The procedures used to perform the mix design are important and can greatly affect the measured properties of the recycled mixture. Since these mix design procedures have varied considerably in the literature, it is difficult to compare test results among the various laboratories.

Whitcomb evaluated a simplified method of mix design for recycled mixtures and compared the results to that of the Marshall and Hveem methods (68). The simplified method consisted of extracting the aged asphalt binder from the RAP and determining the penetration and viscosity of the recovered binder. The asphalt demand of the mixture of recovered aggregate and new aggregate was determined based on the computed surface area of the aggregate determined from the Centrifuge Kerosene Equivalent (CKE) test (proposed ASTM test method under jurisdiction of ASTM Subcommittee D04.20). A nomograph was used to select the type of recycling agent needed to properly modify the existing asphalt cement and, at the same time, satisfy the asphalt demand of the aggregate. Laboratory tests indicated that the measured resilient modulus was higher for the recycled mixtures than for the conventional mixture during permanent deformation testing, but the resilient modulus measured during fatigue tests was lower for the recycled mixtures than for the conventional mixtures. The tensile strength of the recycled mixtures was shown to be lower than the tensile strength of the conventional mixtures. A plot of initial tensile strain versus cycles to failure indicated that at low tensile strains the recycled mixtures had higher fatigue lives than the conventional mixtures.

Little et al. performed a detailed evaluation of laboratory properties of recycled mixtures $(50)$. The Hveem mix design method was used for 
establishing the proper asphalt content, and a trial-and-error procedure was used to ensure that satisfactory properties of the combined asphalt binder were obtained at the optimum asphalt content. Test results on these samples indicated that the recycled materials generally performed equal to or better than the conventional mixture when tested for fatigue resistance and low temperature properties, as predicted by the Hajek-Haas Model. Tests indicated that the recycled mixtures and the conventional mixture were potentially susceptible to the adverse effects of water when samples were evaluated by the seven-day soak and Lottman methods.

Epps et al. characterized a number of recycled mixes that were obtained at various locations in Texas (35) and compared the laboratory properties of these mixtures to the properties of corresponding conventional mixtures. These results showed that, on the average, the Hveem stability of recycled mixtures was less than that for conventional mixtures. The resilient modulus at $0^{\circ} \mathrm{F}$ was about the same for recycled mixtures and for existing mixtures varying in age from 2.5 years to 9 years; at $100^{\circ} \mathrm{F}$, the resilient modulus of recycled mixtures was approximately equal to that of a 2.5 -year-old pavement. The average resilient modulus at $73^{\circ} \mathrm{F}$ was shown to be almost twice as high for conventional mixes as for recycled mixes. After the vacuum immersion and the seven-day soak water conditioning techniques, the percent decrease in resilient modulus was similar.

Resilient modulus test results by Terrel and Fritchen indicated that recycled mixtures compared favorably to conventional mixtures (66).

Little and Epps compared a number of recycled mixtures to a number of conventional mixtures and found that the laboratory properties such as Hveem and Marshall stability, indirect tensile strength, water susceptibility, and resilient modulus were similar for recycled mixtures and conventional mixtures (49).

\section{Asphalt Durability}

Durability has been defined as a resistance to change in original properties of the asphalt during construction and in-service aging (67). For many years, asphalt pavement technologists have tried to evaluate the durability of asphalt binders. These attempts can be generally classed 
into one of two categories: chemical evaluation or physical evaluation. Chemists have tried to predict performance based on the chemical composition of asphalts, while engineers have tried to analyze the physical properties of asphalt binders under accelerated aging and predict performance based on physical properties. Both techniques have had limited success, but neither can predict actual performance with the accuracy desired.

Rostler breaks the asphalt into components of asphaltenes (A), nitrogen bases $(N)$, first acidaffins $\left(A_{1}\right)$, second acidaffins $\left(A_{2}\right)$, and paraffins $(P)$ to analyze the durability properties of the asphalt binder (64). A durability parameter which has been derived and defined as

$$
\left(N+A_{1}\right) /\left(P+A_{2}\right)
$$

has been shown to be related to the measured increase in viscosity with aging.

The thin-film oven test and rolling thin-film oven test have been used in durability tests. These two test methods are used to artificially age an asphalt binder so the durability, which is measured by a decrease in penetration, increase in viscosity, or decrease in ductility, can be determined. The percent change in these physical properties after the thin-film oven test has been used as an indication of the durability of the asphalt cement.

Kemp and Predoeh1 have shown that the California tilt-oven asphalt durability test can be used to predict asphalt hardening in the field over a period of two years (47). This particular test, which uses the same equipment as the rolling thin-film oven test (2), appears to have potential, but use of the test to date has been limited.

Dunning and Mendenhall have shown that the durability of recycled asphalt concrete mixtures is greater than that for conventional mixtures (32). This study indicated that the viscosity of the asphalt cement in recycled mixtures increases at a slower rate than the viscosity of the asphalt cement in conventional mixtures.

\section{Low Temperature Performance}

Design of asphalt mixtures to perform satisfactorily at low 
temperatures is difficult. At low temperatures, asphalt cement tends to become hard and brittle, causing the mixture to crack when the tensile stress caused by contraction exceeds the tensile strength. Specifying a proper asphalt cement and satisfactory mixture properties will minimize this low temperature cracking.

The indirect tensile test, which is useful for characterizing asphalt concrete mixtures, can be used to determine properties of asphalt mixtures. The tensile strength, strain, and stiffness modulus, which are often used to evaluate asphalt mixture properties at low temperatures, are calculated from the following formulas:

$$
\begin{gathered}
S=\frac{2 P}{\pi t D} \\
E=\frac{P(v-0.27)}{t \Delta H} \\
\varepsilon=\frac{S}{E}
\end{gathered}
$$

where

$$
\begin{aligned}
S & =\text { tensile strength, psi } \\
P & =\text { ultimate applied load, lb } \\
D & =\text { diameter of asphalt sample, in. } \\
t & =\text { thickness of asphalt sample, in. } \\
E & =\text { stiffness modulus, psi } \\
V & =\text { Poisson's ratio (generally assumed to be } 0.35 \text { ) } \\
\Delta H & =\text { horizontal deformation, in. } \\
\varepsilon & =\text { tensile strain, in./in. }
\end{aligned}
$$

McLeod has shown, based on work in Canada, that the PenetrationViscosity Number (PVN) of the asphalt binder can be used to predict pavement performance at low temperatures (54). The PVN, which is calculated from the penetration at $77^{\circ} \mathrm{F}$ and the viscosity at $275^{\circ} \mathrm{F}$, is an indicator of temperature susceptibility. To ensure satisfactory performance of an asphalt cement at low temperatures, a minimum penetration of asphalt cement at $77^{\circ} \mathrm{F}$ and a minimum PVN are required. The Department of the Army requires that pavements in cold regions be produced with a low viscosity asphalt cement such as AC-2.5 having a minimum PVN of -0.2 (29). 
Gaw showed that the minimum temperature necessary to cause cracking during the first year after construction can be predicted by a plot of asphalt penetration at $25^{\circ} \mathrm{C}$ versus asphalt penetration at $5^{\circ} \mathrm{C}(39)$. This relationship proved effective in predicting low temperature cracking on a test road in Canada.

Kandhal indicated that asphalt penetration and ductility could be used to predict low temperature cracking in asphalt concrete pavements (45). When the penetration of an asphalt cement approaches 20-25, cracking in the asphalt mixture is likely to occur. Test results indicated that the ductility test, when run at $39.2^{\circ} \mathrm{F}$ or $60^{\circ} \mathrm{F}$, is a better indicator of low temperature performance than when it is conducted at $77^{\circ} \mathrm{F}$.

\section{Water Susceptibility}

Often water is more detrimental to performance of an asphalt concrete pavement than traffic. Water not only affects the underlying unbound layers, but also causes a weakening of the bond between the asphalt cement and aggregate, especially with particular types of aggregates. There have been a number of laboratory tests developed during recent years to predict the damage to asphalt concrete mixtures in the field due to the presence of water. Although none of these water conditioning procedures has been universally accepted by pavement engineers, the test methods most widely used are:

1. 24-hour static immersion (25).

2. Vacuum saturate and 24-hour immersion (proposed ASTM procedure under jurisdiction of Subcommittee D04.22).

3. Lottman test (51).

4. Vacuum saturate and soak for seven days (Texas Transportation Institute procedure).

5. Texas freeze-thaw pedestal test (University of Texas procedure). After the samples have been conditioned, a loss in strength is generally measured by the Marshall stability or indirect tensile test. Some of these water conditioning procedures are in the experimental stages, but preliminary results indicate good correlation between test results and performance. Other tests which are not quantitative include submerging aggregate coated with asphalt cement in boiling water for a period of 
time, shaking vigorously, and estimating percent of exposed aggregate.

\section{Fatigue}

Asphalt concrete pavements often perform satisfactorily for a period of time but eventually fail from fatigue when subjected to a large number of repeated loads. Since the mid 1960 's, much information has been published on fatigue of asphalt concrete. Two general types of tests are normally used to determine fatigue characteristics of an asphalt concrete mixture. One procedure consists of applying repeated loads diametrically across a core until failure occurs. This vertical load results in a horizontal tensile stress and strain which can be computed from the vertical load and lateral displacement measurements. Another procedure consists of testing a beam in repeated flexure using 3- or 4-point loading.

The load and deflection measured during the test is used to compute stress, strain, and modulus of elasticity from the following formulas:

$$
\begin{gathered}
\sigma=\frac{3 a P}{b t^{2}} \\
\varepsilon=\frac{12 t \Delta}{\left(31^{2}-4 a^{2}\right)} \\
E=\frac{P a\left(31^{2}-4 a^{2}\right)}{4 b t^{3} \Delta}
\end{gathered}
$$

where

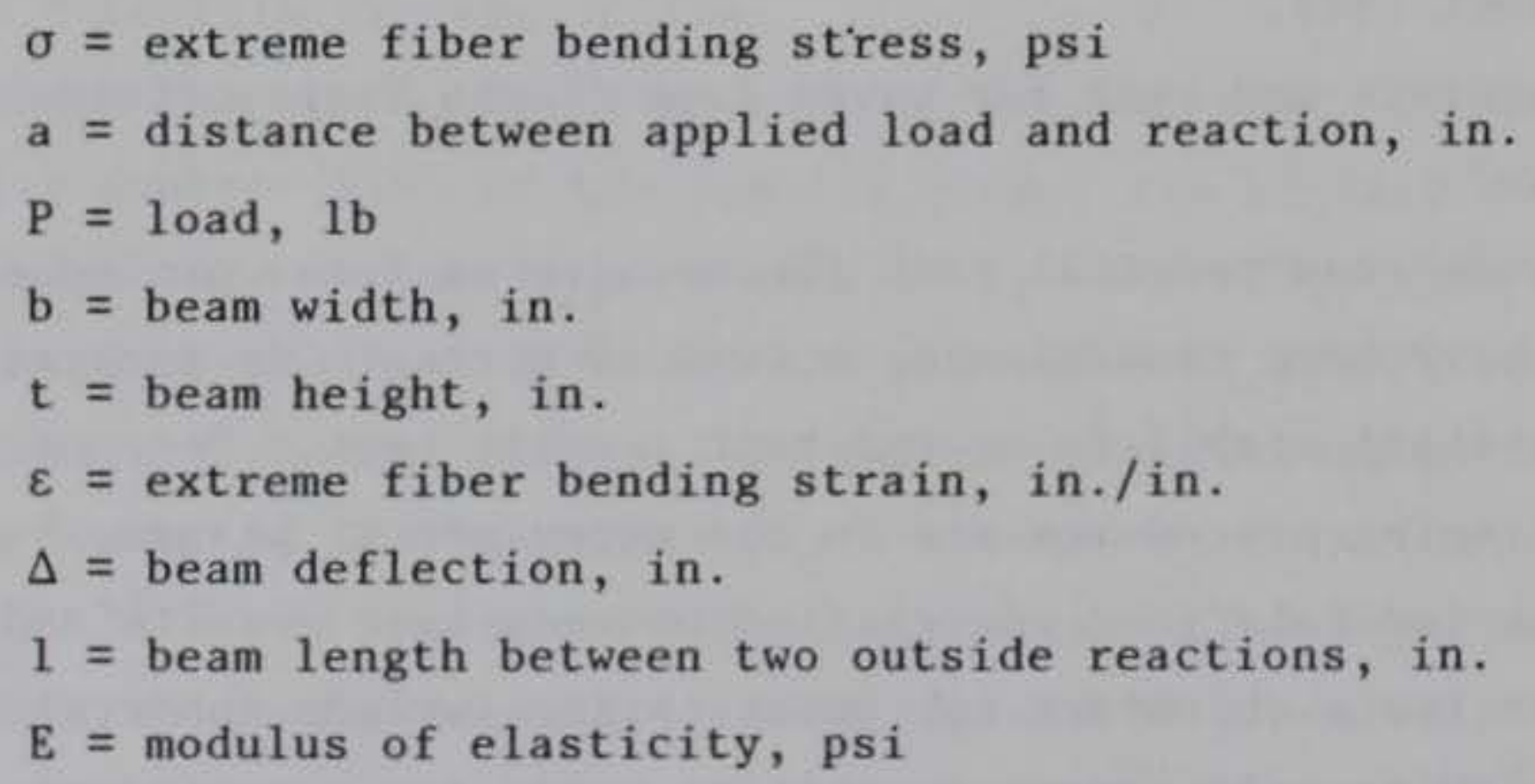


Many authors including Deacon (24), Epps and Monismith (33, 34), Pell and Taylor (61), and Jimenez (43) have indicated a linear relationship exists between $\log$ stress and $\log$ of cycles to failure for flexural fatigue tests conducted on asphalt concrete. This can be expressed as

$$
N_{f}=K_{1}\left(\frac{1}{\sigma}\right)^{n_{1}}
$$

where

$$
\begin{aligned}
\mathrm{N}_{\mathrm{f}} & =\text { number of load applications to failure } \\
\mathrm{K}_{1} & =\text { constant from regression analysis } \\
\sigma & =\text { extreme fiber bending stress, psi } \\
\mathrm{n}_{1} & =\text { constant from regression analysis }
\end{aligned}
$$

The number of load applications to failure can also be expressed in terms of initial strain:

$$
N_{f}=K_{2}\left(\frac{1}{\varepsilon}\right)^{n_{2}}
$$

where

$$
\begin{aligned}
\mathrm{N}_{\mathrm{f}} & =\text { number of load applications to failure } \\
\mathrm{K}_{2} & =\text { constant from regression analysis } \\
\varepsilon & =\text { extreme fiber bending strain, in./in. } \\
\mathrm{n}_{2} & =\text { constant from regression analysis }
\end{aligned}
$$

By solving for the constants $K_{1}, K_{2}, n_{1}$, and $n_{2}$ from a series of tests at different stress levels on a particular asphalt mixture, the number of load applications to failure can be determined for any given stress or strain level.

Constant strain and constant stress modes of loading beams have been used for conducting flexural fatigue tests $(33,34)$. In the constant strain test, a constant deflection is applied to the beam, and the load which decreases with repeated cycles is measured. Failure occurs when the load decreases to some predetermined percentage of the initial load, usually 50 percent. The value of $\sigma$ in Equation 7 is defined as the initial extreme fiber bending stress.

For the constant stress mode of loading, a constant load is applied to the beam and the deflection increases with repeated cycles. Failure 
occurs when the beam actually breaks. One advantage of the constant stress mode of loading is the fact that failure occurs suddenly and there is no judgment in determining failure. For the constant stress test procedure, $\varepsilon$ in Equation 8 is defined as the initial extreme fiber bending strain.

In actual field conditions, the mode of loading is somewhere between constant stress and constant strain. This cannot be completely duplicated in the laboratory.

Many investigators, including Pell $(59,60)$, have stated that the controlled stress mode of loading is applicable for asphalt concrete thicknesses greater than 6 in. $(15.2 \mathrm{~cm})$ while the controlled strain mode of loading is more applicable for thicknesses less than $2 \mathrm{in.}(5.1 \mathrm{~cm})$. Unfortunately, most asphalt concrete thicknesses are somewhere between 2 and 6 in. In general, mixes with high stiffness will provide longer life than mixes with low stiffness in the controlled stress mode of loading (thick pavements), and mixes having low stiffness will provide longer life than mixes with high stiffness in the controlled strain mode of loading (thin pavements).

Kallas and Puzinauskas (44) showed that eight or nine samples were necessary to develop a satisfactory relationship between number of load applications to failure and extreme fiber bending stress when 3 -in. $(7.62 \mathrm{~cm}) \times 3$-in. $\times 15$-in. $(38.1 \mathrm{~cm})$ samples were tested. Test results indicated that the value of $K_{1}$ in Equation 7 ranged from $2 \times 10^{11}$ to $4 \times 10^{18}$ and $n_{1}$ ranged from 3.8 to 6.9 for various asphalt mixtures at $70^{\circ} \mathrm{F}$. The value of $\mathrm{K}_{2}$ in Equation 8 ranged from $3 \times 10^{-11}$ to $6 \times 10^{-5}$ and $n_{2}$ ranged from 2.5 to 4.6 for the same asphalt mixtures at $70^{\circ} \mathrm{F}$.

Miner's law (55) is considered valid by most pavement engineers to analyze fatigue effects in pavement design systems. Miner's law states that failure occurs when

$$
\sum \frac{n_{i}}{N_{i}}=1
$$

where $n_{i}$ is the number of anticipated load applications at a given stress level and $N_{i}$ is the number of load applications to cause failure at that given stress level. Failure is cumulative; hence, the percent 
failure at each load can be added to determine the overall percent failure of the pavement due to a range of loads. This technique allows the cumulative effect of mixed traffic to be determined quantitatively and the overall effect of the traffic to be evaluated.

Since the conduct of fatigue tests is both timely and costly, some empirical formulas that can be used to predict fatigue life have been developed. One such formula as shown below was presented by Francken and Verstraeten (37):

$$
E(N)=\phi \times C \times \frac{V_{B}}{V_{B}+V_{v}} \times N^{-0.21}
$$

where

$$
\begin{aligned}
E(N)= & \text { initial strain to produce failure after } N \text { cycles } \\
\phi= & \text { coefficient depending on the asphaltene content in the } \\
& \text { bitumen } \\
\mathrm{C}= & \text { coefficient, generally } 1.0 \text { for high-quality mixtures } \\
V_{\mathrm{B}}= & \text { volume of bitumen, percent } \\
\mathrm{V}_{\mathrm{v}}= & \text { volume of voids, percent } \\
\mathrm{N}= & \text { number of cycles to produce failure }
\end{aligned}
$$

An equation developed by Pell (59) that is often used to predict service life for a constant strain of $0.0001 \mathrm{in./in.} \mathrm{is}$

$$
\log N\left(\varepsilon=10^{-4}\right)=-16.34+6.03 \log \frac{V_{B}+100}{V_{B}-V_{v}}+5.99 \log \left(T_{R} \& B\right)
$$

where

$$
\begin{aligned}
& \qquad V_{B}=\text { volume of bitumen, percent } \\
& \qquad V_{v}=\text { volume of voids, percent } \\
& T_{R} \& B=\text { ring-and-ball softening point, }{ }^{\circ} \mathrm{C} \\
& \text { The above equations present two simple procedures for predicting } \\
& \text { fatigue life of a pavement which appear to work satisfactorily for the } \\
& \text { mixtures evaluated in these previous studies. A simple procedure for } \\
& \text { predicting fatigue life, such as the two procedures mentioned above, is } \\
& \text { needed so that the relative fatigue life of asphalt concrete mixtures can } \\
& \text { be routinely determined without having to conduct expensive and time- } \\
& \text { consuming fatigue tests. }
\end{aligned}
$$


Bonnaure et al. have shown that rest periods are useful, especially with some types of asphalts, in increasing fatigue life of asphalt concrete (17). Unfortunately, rest periods prolong the time of testing needed to develop a relationship between stress or strain and number of load repetitions to failure; thus rest periods are not usually considered in fatigue testing. Francken (36) has developed a model to consider the effect of rest periods on the fatigue life of asphalt concrete mixtures. The life ratio is defined by

$$
\frac{N_{i}}{N_{c}}=1+2.8\left(\frac{n_{r}}{n_{1}}\right)^{0.44}
$$

where

$$
\begin{aligned}
& N_{i}=\text { number of cycles to failure with rest periods } \\
& N_{c}=\text { number of cycles to failure without rest periods } \\
& n_{r}=\text { number of rest periods } \\
& n_{1}=\text { number of loading cycles }
\end{aligned}
$$

Brown and Pell (23) have suggested that fatigue life observed in the field is often as much as 20 times greater than the fatigue life of test specimens measured in the laboratory. The increased fatigue life in the field is partly caused by the effect of rest periods. This difference between laboratory and field test results highlights the need to develop relationships between measured laboratory results and observed field results. Laboratory fatigue tests can be used to compare mixes to determine a relative life in the field, but the predicted number of load applications often does not compare very well with actual numbers that are determined in the field.

Pell (60) showed that the amount of air voids in the asphalt concrete mixture greatly affected the fatigue performance. A proper mixture design can ensure that voids in the mixture are in the proper range and also adequate compaction during construction is needed to keep voids in the field within an allowable range.

Another method to predict fatigue life makes use of fracture mechanics to determine the estimated rate of crack growth (52). This approach assumes that the increase in deflection of a beam under repeated load is due to crack growth which is determined from the following relationship: 


$$
\frac{d c}{d N}=a b N^{b-1}
$$

where

$$
\begin{aligned}
c & =\text { crack length } \\
N & =\text { number of cycles } \\
a, b & =\text { constants from regression analysis }
\end{aligned}
$$

The rate of crack growth is also a function of stress concentration factor which is related to crack length and deflection. This relationship between rate of crack growth and stress concentration factor is:

$$
\frac{d c}{d N}=A K_{I}^{n}
$$

where

$$
\begin{aligned}
c & =\text { crack length } \\
N & =\text { number of cycles } \\
K_{I} & =\text { stress concentration factor } \\
A, n & =\text { fatigue parameters }
\end{aligned}
$$

This approach for analyzing fatigue data has been used by a number of investigators; however, the procedure which expresses the number of cycles to failure as a function of stress or strain is presently the most popular method of analyzing the data.

\section{Layered Elastic Analysis}

In recent years, emphasis has been placed on the development of computer programs to obtain the stresses and strains within the various pavement layers. These programs are useful in computing data needed to analyze the fatigue characteristics of a pavement system. Some of the computer programs available include finite element programs, Chevron $\mathrm{N}$ Layer Elastic program, Shell BISTRO program, and Shell BISAR program. These programs allow the rapid determination of expected pavement performance for a range of material properties. Typically, the tensile stress at the bottom of the bound layers and the compressive stresses at the top of the unbound layers, especially the subgrade, are critical. 
The basic plan of test for this project consists of comparing the laboratory properties of hot recycled mixtures to those of conventional mixtures with emphasis placed on fatigue characteristics. To make this comparison, samples of in-place aged asphalt concrete were obtained from pavements at three locations where recycling was planned. Most of the mixtures sampled had been in service for 15 to 25 years, and the usual long-term problems such as cracking and general deterioration had occurred.

Samples of asphalt concrete were obtained from Lajes Air Force Base, Azores Islands, Portugal; Pope Air Force Base, North Carolina; and Interstate 55 near Grenada, Mississippi. New aggregates used in preparing the conventional mixtures and the recycled mixtures consisted of crushed limestone from Alabama and crushed gravel from Mississippi. An AC-5 and an $\mathrm{AC}-20$ asphalt cement obtained from Southland 0il Company were used for preparing recycled and conventional mixtures, respectively, for this study. The recycling agent used to prepare recycled mixtures was Cyclogen $\mathrm{H}$, a proprietary material produced by the Witco Chemical Corporation, Bakersfield, California. This recycling agent had previously been used on a large number of asphalt concrete recycling jobs and is considered typical of most recycling agents.

Recycled mixtures were prepared from samples of reclaimed asphalt pavement obtained from each location. Mixtures prepared with materials from each sampling location consisted of a recycled mixture containing low viscosity asphalt cement $(\mathrm{AC}-5)$ and a recycled mixture containing the recycling agent. Conventional mixtures were prepared with crushed gravel and crushed limestone mixed with $\mathrm{AC}-20$. Limestone was used as the new aggregate to prepare a conventional mixture for comparison to recycled mixtures from Lajes Air Force Base since the aggregate recovered from the RAP at Lajes was similar in shape and texture to limestone. Crushed gravel was used as the new aggregate to prepare recycled mixtures using materials from Pope Air Force Base and Interstate 55. The new aggregates were selected from existing laboratory supplies to be similar to the aggregates existing in the reclaimed asphalt pavement. This procedure resulted in two conventional mixtures and six recycled 
mixtures as shown in Table 1. The same mixture was used to represent the conventional mixture for Pope Air Force Base and Interstate 55.

These eight asphalt concrete hot mixtures were designed to meet Corps of Engineers criteria; however, criteria for recycled mixtures were being developed in conjunction with this study, hence, many requirements have subsequently been changed. Mix designs for the conventional mixtures determined the aggregate gradation and the amount of AC-20 to be added to the mixture. The mix designs for the recycled mixtures determined the percent of RAP, the percent of new aggregate, and the percent of new asphalt cement or recycling agent to be used in the mixture. All mix designs were conducted in accordance with established procedures specified in "Bituminous Pavements Standard Practice," TM 5-822-8 (26) and "Test Methods for Bituminous Paving Materials," MIL-STD-620A (25). The mix designs for the recycled mixtures were conducted in accordance with a standard practice manual for recycled pavements being developed by the U. S. Army Engineer Waterways Experiment Station.

After the mix design for each mixture was developed, samples were prepared for determination of fatigue resistance, resilient modulus, Marshall stability, indirect tensile, and water susceptibility. These tests were conducted for each of the eight mixtures so that a comparison between the recycled and conventional mixtures and between the recycled mixtures containing recycling agent and the recycled mixtures containing AC -5 could be made. To evaluate the potential performance, the tests shown in Table 2 were conducted on each mixture. The penetration, viscosity, ductility, rolling thin-film oven, softening point, and specific gravity tests were conducted on the combined asphalt binder to be used in each mixture. The penetration, viscosity, ductility, softening point, specific gravity, and weight loss tests were also conducted on the asphalt binders after the rolling thin-film oven test. Asphalt cement was extracted and recovered from each of the prepared mixtures and tested for penetration, ductility, viscosity, softening point, and specific gravity to evaluate the effect of mixing on the properties of the asphalt binder.

After the material and mixture properties had been determined, the stiffness data were used as input into the Shell BISAR program for two typical pavement sections to predict the stresses and strains that would 
TABLE 1.--Summary of Mixtures Evaluated

\begin{tabular}{|c|c|c|c|}
\hline \multirow[b]{2}{*}{ Mixture Type } & \multicolumn{3}{|c|}{ Location } \\
\hline & Pope Air Force Base & Lajes Air Force Base & Interstate 55 , Mississippi \\
\hline New mixture & Crushed gravel and $\mathrm{AC}-20$ & Crushed limestone and $\mathrm{AC}-20$ & Crushed gravel and $\mathrm{AC}-20$ \\
\hline $\begin{array}{l}\text { Recycled with } \\
\text { recycling agent }\end{array}$ & $\begin{array}{l}\text { Reclaimed mixture, } \\
\text { crushed gravel, and } \\
\text { recycling agent }\end{array}$ & $\begin{array}{l}\text { Reclaimed mixture, crushed } \\
\text { limestone, and recycling } \\
\text { agent }\end{array}$ & $\begin{array}{l}\text { Reclaimed mixture, } \\
\text { crushed gravel, and } \\
\text { recycling agent }\end{array}$ \\
\hline Recycled with AC-5 & $\begin{array}{l}\text { Reclaimed mixture, } \\
\text { crushed gravel, and } \\
\text { AC-5 }\end{array}$ & $\begin{array}{l}\text { Reclaimed mixture, crushed } \\
\text { limestone, and } \mathrm{AC}-5\end{array}$ & $\begin{array}{l}\text { Reclaimed mixture, } \\
\text { crushed gravel, and } \mathrm{AC}-5\end{array}$ \\
\hline
\end{tabular}


TABLE 2.--Tests Conducted on Each Mixture

\begin{tabular}{|c|c|}
\hline $\begin{array}{c}\text { Tests Conducted on Combined } \\
\text { Asphalt Binder }\end{array}$ & $\begin{array}{l}\text { Tests Conducted on } \\
\text { Asphalt Concrete }\end{array}$ \\
\hline Penetration at $40^{\circ} \mathrm{F}$ and $77^{\circ} \mathrm{F}$ (5) & Marshall stability at $140^{\circ} \mathrm{F}$ (25) \\
\hline $\begin{array}{l}\text { Viscosity at } 140^{\circ} \mathrm{F}, 225^{\circ} \mathrm{F} \text {, } \\
\text { and } 275^{\circ} \mathrm{F} \text { (3) }\end{array}$ & $\begin{array}{l}\text { Indirect tensile at } 40^{\circ} \mathrm{F} \text { and } \\
77^{\circ} \mathrm{F}\end{array}$ \\
\hline Ductility at $40^{\circ} \mathrm{F}$ and $77^{\circ} \mathrm{F}$ (1) & $\begin{array}{l}\text { Flexural fatigue at } 40^{\circ} \mathrm{F} \text { and } \\
77^{\circ} \mathrm{F}\end{array}$ \\
\hline Rolling thin-film oven test (2) & $\begin{array}{l}\text { Water conditioning by static } \\
\text { immersion ( } 25)\end{array}$ \\
\hline Softening point (9) & $\begin{array}{l}\text { Water conditioning by vacuum } \\
\text { saturation and } 24 \text {-hour } \\
\text { immersion }\end{array}$ \\
\hline Specific gravity (12) & $\begin{array}{l}\text { Resilient modulus at } 40^{\circ} \mathrm{F} \text { and } \\
77^{\circ} \mathrm{F}\end{array}$ \\
\hline
\end{tabular}

occur in each of the mixtures. The computed stresses and strains were used along with the fatigue models developed from the flexural fatigue tests to predict performance of the recycled and conventional mixtures. This analysis was performed to provide a relative indication of field performance for recycled and conventional mixtures. 


\section{PART IV: DESCRIPTION OF TESTS}

\section{$\underline{\text { Mix Designs }}$}

The entire study of mixture properties for recycled mixtures as compared to properties of conventional mixtures is highly dependent on the procedures used to perform the mix design. At the start of work on this project, there was no widely accepted procedure for mix design of recycled mixtures, although many agencies had their own procedures. For the most part, procedures used to conduct mix designs for recycled mixtures are very similar to those for conventional mixtures. A mixture placed in the field should have approximately the same properties whether it is a conventional or a recycled mixture. The properties considered important in a mix design include: (a) the properties of the aggregates; i.e., gradation, crushed faces, flat and elongated count, Los Angeles abrasion, soundness, specific gravity, and absorption, and (b) the properties of the asphalt binder; i.e., penetration, viscosity, and ductility. The important mixture properties include unit weight, stability, flow, voids in the total mixture, and voids filled with asphalt.

The Corps of Engineers criteria for designing asphalt mixtures for airfields allow the use of 75 blows with the Marshall hammer or the use of the gyratory machine for compacting samples $(25,26)$. The gyratory machine was used for this study at the selected calibration to produce the same density as obtained with 75 blows with a manul hammer. One additional step in designing recycled mixtures was the evaluation of the penetration of the combined asphalt binder prior to and after mixing. For mix design purposes, the penetration was increased by decreasing the amount of RAP used in the mixture. This decrease in amount of RAP resulted in an increase in the amount of new aggregate and an increase in asphalt cement or recycling agent.

\section{Asphalt Binder Tests}

After the mix design had been developed, a number of tests were conducted on the combined asphalt binder prepared by mixing the same percentages of each binder material as determined by the mix design. For 
example, if the mix design indicated using 60 percent RAP with a 5 percent asphalt content and 2 percent additional binder, then the combined binder would include three parts aged asphalt cement $(0.60 \times 5)$ and two parts new binder.

After extracting the binder from the existing RAP with a rotorex extractor (6), the dust that was carried over into the solution of solvent was removed from the asphalt binder with a high-speed centrifuge. This procedure allowed the asphalt binder to be recovered from the mixtures by the Abson method (7) without a significant amount of dust remaining to affect the measured properties of the binder. After the binder was recovered, it was mixed with the AC-5 or recycling agent at the proper percentages and prepared for testing.

The penetration of the asphalt binder was determined at $40^{\circ}$ and $77^{\circ} \mathrm{F}$. At $77^{\circ} \mathrm{F}$, the standard weight and time of 100 grams and 5 seconds, respectively, was used in determining the penetration. At $40^{\circ} \mathrm{F}$, weights and times of 200 grams and 10 seconds, respectively, and 100 grams and 5 seconds, respectively, were used in determining the penetration. The ductility test (1) was conducted at $40^{\circ} \mathrm{F}$ and $77^{\circ} \mathrm{F}$. The rate of elongation was set at $5 \mathrm{~cm}$ per minute at $77^{\circ} \mathrm{F}$ and $1 \mathrm{~cm}$ per minute at $40^{\circ} \mathrm{F}$. The kinematic viscosity (3) was conducted at $225^{\circ} \mathrm{F}$ and $275^{\circ} \mathrm{F}$, while the absolute viscosity of the asphalt binder was measured at $140^{\circ} \mathrm{F}$.

All of the tests on the asphalt binder mentioned above were:

1. Conducted on the original combined asphalt binder (including the recycling agent, if used).

2. Conducted on the combined asphalt binder after the rolling thinfilm oven test.

3. Conducted on the asphalt binder recovered from the beams used for the fatigue test.

\section{Aspha1t Mix Tests}

The Marshall stability test, which is useful in conducting mix design and predicting performance, was conducted on each of the eight mixtures analyzed. Experience has shown that a mix design produced with an aggregate of satisfactory quality and gradation and with an asphalt of satisfactory type and quality will produce a mixture meeting the Marshall 
stability requirements. Generally, failure to meet the Marshall stability requirements is an indication that improper asphalt cement was used, improper aggregate was used, or mix design was improperly conducted. A high Marshall stability does not necessarily mean better performance; often the contrary is true, since a high stability often indicates that the mix is brittle, which results in premature cracking.

The Corps of Engineers minimum requirement for Marshall stability is $1800 \mathrm{lb}(817 \mathrm{~kg})$ for high-pressure tire design and $500 \mathrm{lb}(227 \mathrm{~kg})$ for low-pressure tire design. These minimum values for stability have been established over a period of years based on experience with various types of mixtures. The mixtures for this study were designed for airfields; therefore, the $1800-1 \mathrm{~b}(817 \mathrm{~kg})$ minimum stability was desired.

The indirect tensile test has been widely used to characterize asphalt mixtures. This test is simple to perform, and unlike the Marshall stability, the results can be analyzed rationally to compute the stresses and strains within the sample. Cracking within a pavement generally results from exceeding the tensile strength of the binder; hence, the indirect tensile test is used in evaluating the potential of an asphalt mixture to crack at low temperatures.

For this study, the indirect tensile test was conducted at $40^{\circ} \mathrm{F}$ and $77^{\circ} \mathrm{F}$. It was conducted at a load rate of $2 \mathrm{in} .(5.1 \mathrm{~cm})$ per minute on $4-i n .(10.2 \mathrm{~cm})$ diameter cores prepared in the laboratory and compacted in the gyratory machine.

With the recent emphasis on rational design of pavements, the resilient modulus test, a simple and inexpensive test, has become increasingly important. The resilient modulus is a measure of stiffness of the mixture under repeated load and is used as input into a layered elastic computer program to obtain stresses and strains in the mixture for various pavement sections and loading conditions.

The Schmidt resilient modulus device (65) was used to measure the resilient modulus for each of the eight mixtures at $40^{\circ} \mathrm{F}$ and $77^{\circ} \mathrm{F}$. Conducting this test over a range of temperatures provides the information needed to determine the sensitivity of resilient modulus to a change in temperature. The resilient modulus test was conducted on 4-in. diameter cores prepared and compacted in the laboratory. Samples tested for resilient modulus were loaded in the same way as the samples for the 
indirect tensile test; however, the samples for resilient modulus were subjected to repeated stress applications at a stress level substantially below the strength of the sample. The samples were loaded for 0.1 second at a load of $8.2 \mathrm{psi}$ and a frequency of 20 cycles per minute.

The static immersion compression test has been used by the Corps of Engineers for a number of years to evaluate the water susceptibility of asphalt mixtures (25). Six samples for each mixture were prepared at optimum asphalt content. Three of these samples were tested using conventional test procedures to determine the Marshall stability, while the other three samples were soaked for 24 hours in a water bath at $140^{\circ} \mathrm{F}$ prior to being tested for stability. An index of retained stability was determined by the following formula:

$$
\text { Index of Retained Stability }=\frac{\text { Stability After } 24 \text {-Hour Soak }}{\text { Stability After } 30 \text {-Minute Soak }}
$$

The Corps of Engineers has established that an index of retained stability below 0.75 is cause for rejection of a mixture. Generally, when a mixture fails to meet the requirements of this test, another aggregate source is selected for use or an antistrip agent is used to improve the mixture's resistance to the adverse effects of water.

Six samples for each mixture were prepared at optimum asphalt content for determination of water susceptibility using the indirect tensile test. After immersing one half of the samples at $77^{\circ} \mathrm{F}$ for 30 minutes and the other half at $77^{\circ} \mathrm{F}$ for 24 hours, the tensile strength was measured using the indirect tensile test. An index of retained strength was computed for the indirect tensile test, similar to that computed for the Marshall stability test shown in Equation 15.

Since many engineers feel that the static immersion test does not properly condition the samples to represent field conditions for the asphalt mixture, the vacuum saturation and immersion test was also used in this study. This test involves applying a vacuum to the samples for 30 minutes, then immersing these samples in a water bath for 24 hours at $140^{\circ} \mathrm{F}$. After immersion of the samples for 24 hours, an index of retained strength for the Marshall stability (25) and for the indirect tensile test (proposed ASTM standard under jurisdiction of Subcommittee D04.20) was determined. 
The static immersion and the vacuum saturation and immersion test procedures allow for a comparison of the retained strengths for recycled and for conventional mixtures. These two tests were used for this study because of their simplicity and wide use among paving engineers.

The fatigue tests were conducted with MTS Systems Corporation closedloop electrohydraulic testing equipment (Fig. 2). This equipment can be set to apply any desired load or deflection to the sample. The load and deflection are recorded on a plotter and the number of cycles are counted. An apparatus built by Cox \& Sons in California, which produces 4-point loading of the beam, was used to hold the asphalt concrete beam in place during the testing (Fig. 3).

The asphalt concrete beams were prepared with densities equal to 98 percent of the 75-blow Marshall density which is approximately equal to the density built into pavements during construction. The beams were compacted in a 3 -in. $(7.6 \mathrm{~cm}) \times 3$-in. $\times 15-i n .(38.1 \mathrm{~cm})$ mold with a hand hammer which was modified to have a 3-in. $\times 3$-in. square foot. The beam and mold were moved horizontally back and forth underneath the hammer during compaction so that each point of the beam was equally compacted. This compaction technique resulted in an impact-kneading type compaction. After the beams were compacted, a steel plate was placed over the top of the beam while it was inside the mold and a static load was applied to it to produce an even, smooth surface on all sides. After the beam was removed from the mold, a metal nut was attached with epoxy to the side of the beam at the neutral axis. The nut was attached to the linear variable differential transducer (LVDT) so that the deflection of the beam could be measured during the fatigue tests. Each beam was allowed to cure for a minimum of one week at room temperature to give the mixture of asphalt and recycling agent or $\mathrm{AC}-5$ asphalt cement time to stabilize inside the recycled mixtures prior to testing.

Prior testing had indicated that approximately 8-9 beams were generally sufficient to develop a suitable straight-line plot for log stress versus $\log$ cycles to failure (44). To ensure that at least 8 beams were properly tested, 12 beams were prepared for each mixture. Each of the eight mixtures was tested at two temperatures, requiring 192 beams for fatigue testing. When a malfunction in the equipment was observed during operation, the beam being tested was discarded and the results voided. 


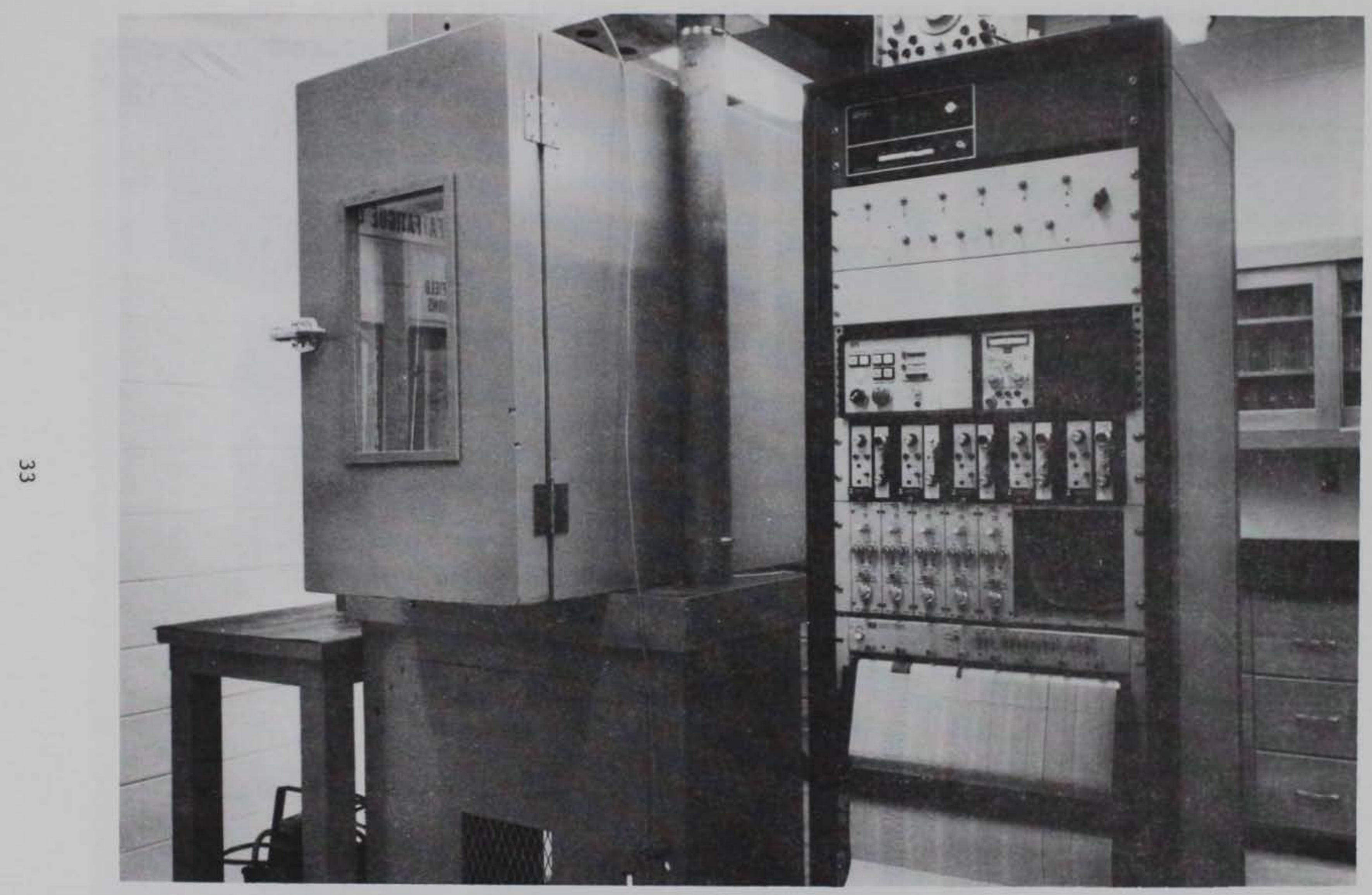

FIG. 2.--Fatigue Test Equipment - Environmental Chamber and Control Panel 


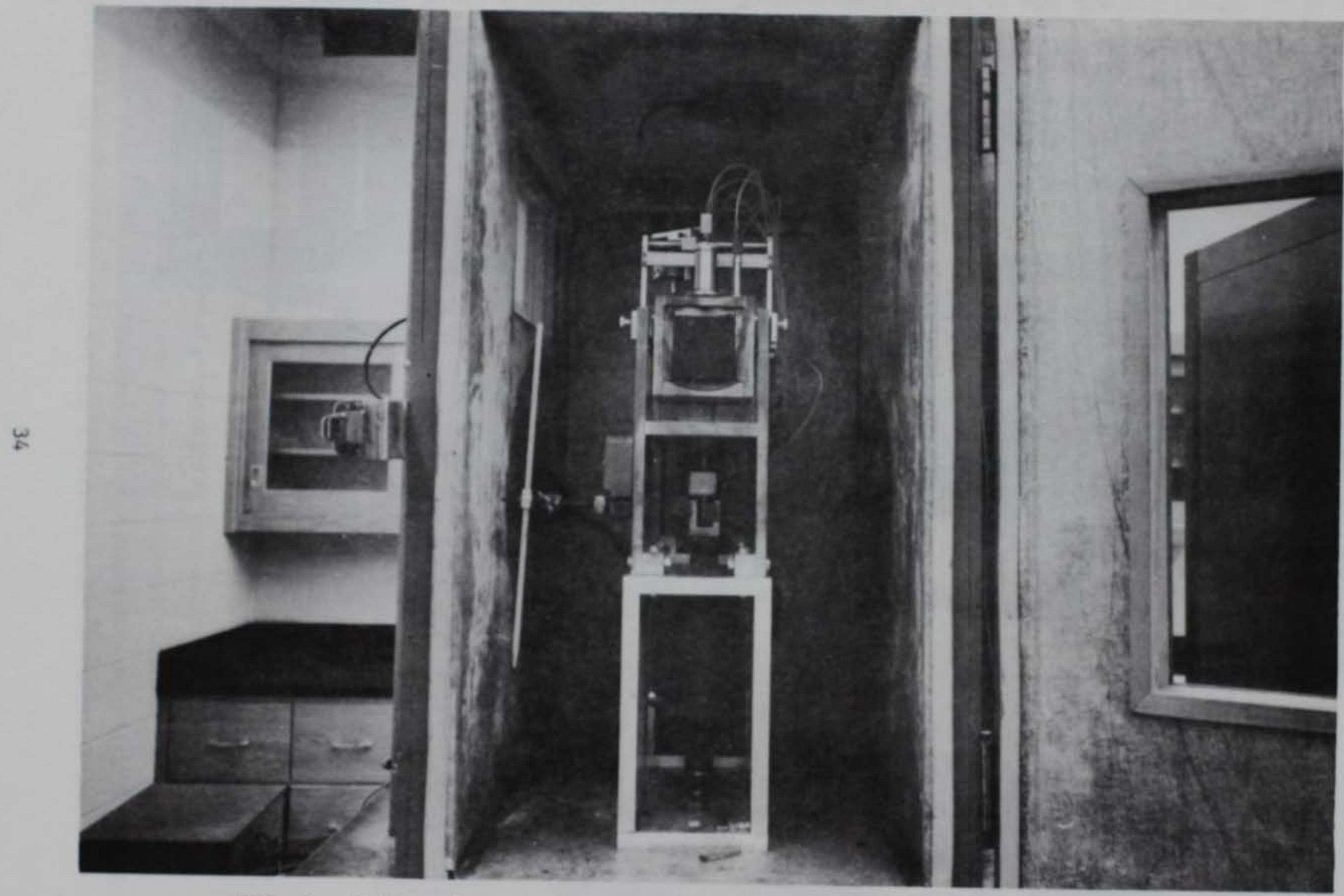

FIG. 3.--Fatigue Test Equipment - Environmental Chamber and Beam Test Set-Up 
The constant stress mode of loading was used to conduct all tests for this study. One reason for the selection of the constant stress mode of loading was that failure is better defined. Also, because hot recycling projects are generally used in conjunction with thick pavements, this mode of loading is the most desirable.

A sine wave load function was applied to the beam with the top peak representing a tensile stress in the bottom of the beam and the bottom peak representing an equal compressive stress in the bottom of the beam. Each beam was loaded at 30 cycles per minute with no rest periods. A preload approximately equal to the weight of the beam was applied pushing upward on the beam during the test to prevent sagging of the beam under its own weight.

Flexure fatigue tests were conducted at $40^{\circ}$ and $77^{\circ} \mathrm{F}$. Conducting the tests at two temperatures gives an indication of the temperature susceptibility of the mixtures and also indicates fatigue performance at low and intermediate temperatures. 


\section{Properties of Reclaimed Asphalt Pavement}

The RAP was obtained from three locations where plans had been made to recycle the existing asphalt concrete. The recycling projects at Lajes Air Force Base and Pope Air Force Base were completed; however, the recycling project on Interstate 55 was canceled because of exceptionally high bids from contractors.

An analysis of the materials from each of the three locations was made to evaluate the in-place material; test results are shown in Table 3. The aggregates from the three locations were similar; although, tests on the aggregate from Lajes Air Force Base and Interstate 55 showed a higher amount of material passing the No. 200 sieve than the aggregate from Pope Air Force Base. The aggregate from all three sources was 100 percent crushed. The penetration of the recovered asphalt binder varied from 4 on Interstate 55 to 28 at Pope Air Force Base. A penetration between 15 and 28 is considered normal for aged asphalt pavements, but a penetration of 4 is abnormally low. The asphalt cement extracted from the RAP varied from 3.5 percent on Interstate 55 to 5.2 percent at Lajes Air Force Base. The low asphalt content in the mix from Interstate 55 could have resulted in a higher oxidation rate, which partially explains the low asphalt penetration.

\section{$\underline{\text { Mix Design }}$}

The mix design for each of the mixtures was developed using the procedures for conventional mixtures with additional steps taken to ensure that the combined asphalt binder properties were reasonable. The properties of the recycling agent, $\mathrm{AC}-5$, and $\mathrm{AC}-20$ asphalt concrete used in the mixture design are shown in Table 4.

Table 5 is a summary of the mix designs for the three mixtures prepared to represent the material from Pope Air Force Base. The gradation of the new aggregate used in each of the eight mixtures was controlled so that the gradation of the combined aggregate in each of the mixtures was relatively constant. The aggregate gradations for the three mixtures 
TABLE 3.--Analysis of In-Place Mixtures

\begin{tabular}{|c|c|c|c|}
\hline & \multicolumn{3}{|c|}{ Location } \\
\hline & Pope AFB & Lajes AFB & Interstate 55 \\
\hline $\begin{array}{c}\text { Aggregate Gradation } \\
\text { (Sieve Size) }\end{array}$ & $\begin{array}{l}\text { Percent } \\
\text { Passing } \\
\end{array}$ & $\begin{array}{l}\text { Percent } \\
\text { Passing }\end{array}$ & $\begin{array}{l}\text { Percent } \\
\text { Passing } \\
\end{array}$ \\
\hline $\begin{array}{l}\text { 3/4-in. } \\
1 / 2-\text { in. } \\
3 / 8-i n . \\
\text { No. } 4 \\
\text { No. } 8 \\
\text { No. } 16 \\
\text { No. } 30 \\
\text { No. } 50 \\
\text { No. } 100 \\
\text { No. } 200\end{array}$ & $\begin{array}{r}100 \\
94 \\
86 \\
69 \\
58 \\
49 \\
37 \\
21 \\
11 \\
5.8\end{array}$ & $\begin{array}{l}98 \\
90 \\
80 \\
63 \\
50 \\
39 \\
32 \\
22 \\
12 \\
9.1\end{array}$ & $\begin{array}{r}100 \\
97 \\
90 \\
67 \\
51 \\
41 \\
34 \\
21 \\
13 \\
9.0\end{array}$ \\
\hline $\begin{array}{l}\text { Asphalt Content, } \\
\text { percent } \\
\text { Asphalt Penetration, } \\
0.1 \mathrm{~mm}\end{array}$ & 4.7 & 5.2 & $\begin{array}{l}3.5 \\
4\end{array}$ \\
\hline $\begin{array}{l}\text { Asphalt Cement } \\
\text { Viscosity } \\
\text { centistokes }\end{array}$ & & & \\
\hline $\begin{array}{l}275^{\circ} \mathrm{F} \\
225^{\circ} \mathrm{F} \\
140^{\circ} \mathrm{F}\end{array}$ & $\begin{array}{r}2,500 \\
25,500 \\
38,100,000\end{array}$ & $\begin{array}{c}26,000 \\
* \\
*\end{array}$ & $\begin{array}{c}80,500 \\
* \\
*\end{array}$ \\
\hline $\begin{array}{l}\text { Asphalt Specific } \\
\text { Gravity }\end{array}$ & 1.061 & 1.070 & 1.082 \\
\hline $\begin{array}{l}\text { Coarse Aggregate, } \\
\text { Percent Crushed } \\
\text { Faces }\end{array}$ & 100 & 100 & 100 \\
\hline $\begin{array}{l}\text { Aggregate Apparent } \\
\text { Specific Gravity } \\
(10,11)\end{array}$ & 2.64 & 2.70 & 2.61 \\
\hline $\begin{array}{l}\text { Aggregate Absorp- } \\
\text { tion }(10,11)\end{array}$ & 1.2 & 1.4 & 0.5 \\
\hline
\end{tabular}

* Asphalt too viscous to flow through viscometer. 
TABLE 4.--Properties of Recycling Agent, AC-5, and AC-20 Asphalt Cements

\begin{tabular}{|c|c|c|c|}
\hline Property & $\mathrm{AC}-20$ & $\mathrm{AC}-5$ & $\begin{array}{c}\text { Recycling } \\
\text { Agent }\end{array}$ \\
\hline Specific Gravity & 1.028 & 1.023 & -- \\
\hline \multicolumn{4}{|l|}{ Viscosity } \\
\hline $140^{\circ} \mathrm{F}$, poises & 2654 & 595 & 95 \\
\hline $225^{\circ} \mathrm{F}, \mathrm{Cst}$ & 2690 & 1087 & 216 \\
\hline $275^{\circ} \mathrm{F}$, Cst & 457 & 253 & 61 \\
\hline \multicolumn{4}{|l|}{ Penetration } \\
\hline $77^{\circ} \mathrm{F}, 100 \mathrm{gm}, 5 \mathrm{sec}, 0.1 \mathrm{~mm}$ & 81 & 164 & -- \\
\hline $40^{\circ} \mathrm{F}, 100 \mathrm{gm}, 5 \mathrm{sec}, 0.1 \mathrm{~mm}$ & 9 & 28 & -- \\
\hline $40^{\circ} \mathrm{F}, 200 \mathrm{gm}, 60 \mathrm{sec}, 0.1 \mathrm{~mm}$ & 42 & 94 & -- \\
\hline \multicolumn{4}{|l|}{ Ductility } \\
\hline $77^{\circ} \mathrm{F}, 5 \mathrm{~cm} / \mathrm{min}, \mathrm{cm}$ & $150+$ & $150+$ & -- \\
\hline $40^{\circ} \mathrm{F}, 1 \mathrm{~cm} / \mathrm{min}, \mathrm{cm}$ & 11 & $150+$ & -- \\
\hline RTF0, percent loss & 0.16 & 0.58 & 0.16 \\
\hline \multicolumn{4}{|l|}{ Viscosity } \\
\hline $140^{\circ} \mathrm{F}$, poises & 8409 & 2120 & 96 \\
\hline $225^{\circ} \mathrm{F}, \mathrm{Cst}$ & 4479 & 1760 & 253 \\
\hline $275^{\circ} \mathrm{F}, \mathrm{Cst}$ & 700 & 389 & 71 \\
\hline \multicolumn{4}{|l|}{ Penetration } \\
\hline $77^{\circ} \mathrm{F}, 100 \mathrm{gm}, 5 \mathrm{sec}, 0.1 \mathrm{~mm}$ & 46 & 96 & -- \\
\hline $40^{\circ} \mathrm{F}, 100 \mathrm{gm}, 5 \mathrm{sec}, 0.1 \mathrm{~mm}$ & 9 & 18 & -- \\
\hline $40^{\circ} \mathrm{F}, 200 \mathrm{gm}, 60 \mathrm{sec}, 0.1 \mathrm{~mm}$ & 24 & 54 & -- \\
\hline \multicolumn{4}{|l|}{ Ductility } \\
\hline $77^{\circ} \mathrm{F}, 5 \mathrm{~cm} / \mathrm{min}, \mathrm{cm}$ & 114 & 148 & -- \\
\hline $40^{\circ} \mathrm{F}, 1 \mathrm{~cm} / \mathrm{min}, \mathrm{cm}$ & 3 & 92 & -- \\
\hline
\end{tabular}


TABLE 5.--Mix Designs for Material from Pope Air Force Base

\begin{tabular}{|c|c|c|c|c|}
\hline & Specifications & $\begin{array}{l}\text { Conventional } \\
\text { Mixture }\end{array}$ & $\begin{array}{c}40 \% \text { RAP } \\
60 \% \text { New Aggregate } \\
\text { AC-5 }\end{array}$ & $\begin{array}{c}70 \% \text { RAP } \\
30 \% \text { New Aggregate } \\
\text { Recycling Agent }\end{array}$ \\
\hline $\begin{array}{l}\text { Aggregate Gradation } \\
\text { (Sieve Size) } \\
\end{array}$ & $\begin{array}{l}\text { Percent } \\
\text { Passing }\end{array}$ & $\begin{array}{l}\text { Percent } \\
\text { Passing }\end{array}$ & $\begin{array}{l}\text { Percent } \\
\text { Passing }\end{array}$ & $\begin{array}{l}\text { Percent } \\
\text { Passing }\end{array}$ \\
\hline $\begin{array}{l}\text { 3/4-in. } \\
1 / 2-i n . \\
3 / 8-i n . \\
\text { No. } 4 \\
\text { No. } 8 \\
\text { No. } 16 \\
\text { No. } 30 \\
\text { No. } 50 \\
\text { No. } 100 \\
\text { No. } 200\end{array}$ & $\begin{array}{c}100 \\
82-96 \\
75-89 \\
59-73 \\
46-60 \\
34-48 \\
24-38 \\
15-27 \\
8-18 \\
3-6\end{array}$ & $\begin{array}{r}100 \\
90 \\
82 \\
65 \\
54 \\
42 \\
32 \\
23 \\
12 \\
4.5\end{array}$ & $\begin{array}{r}100 \\
89 \\
82 \\
67 \\
54 \\
41 \\
31 \\
22 \\
10 \\
4.8\end{array}$ & $\begin{array}{r}100 \\
90 \\
82 \\
67 \\
54 \\
42 \\
32 \\
21 \\
11 \\
6.0\end{array}$ \\
\hline $\begin{array}{l}\text { Optimum Asphalt Content, } \\
\text { percent }\end{array}$ & -- & 7.1 & 7.0 & 5.9 \\
\hline $\begin{array}{l}\text { old } \\
\text { New }\end{array}$ & -- & -- & $\begin{array}{l}1.9 \\
5.1\end{array}$ & $\begin{array}{l}3.3 \\
2.6\end{array}$ \\
\hline Stability, lb & $1800 \mathrm{~min}$. & 2140 & 1900 & 1785 \\
\hline Flow, 0.01 in. & $16 \max$. & 12 & 13 & 9 \\
\hline Voids Total Mix, percent & $3-5$ & 4.2 & 4.0 & 4.0 \\
\hline $\begin{array}{l}\text { Voids Filled with Asphalt, } \\
\text { percent }\end{array}$ & $70-80$ & 78.0 & 80.0 & 79.0 \\
\hline Unit Weight, pcf & -- & 142.2 & 143.0 & 145.2 \\
\hline
\end{tabular}


for Pope AFB met the recommended requirements, and there was very little difference between the measured gradations. The biggest difference in the gradation of the three mixtures occurred in the recycled mixture containing the recycling agent. This mixture had 6.0 percent passing the No. 200 sieve, greater than the 4.5 percent for the conventional mixture and the 4.8 percent for the recycled mixture with $\mathrm{AC}-5$ asphalt cement as the additional binder. Optimum asphalt contents differed greatly, also. The recycled mixture using the recycling agent required only 5.9 percent total binder, while the conventional mixture required 7.0 percent and the recycled mixture using $\mathrm{AC}-5$ asphalt cement required 7.1 percent total binder. This difference in optimum asphalt content is due to differences in laboratory density, which is probably partially due to the greater percentage of material passing the No. 200 sieve in the recycled mixture containing recycling agent and may be partially due to the increased lubricating effect of the recycling agent.

Table 6 is a summary of the mix designs conducted on the three mixtures representing the material from Lajes Air Force Base. Aggregate gradations for the three mixtures are nearly equal. The conventional mixture, when compared to the recycled mixtures, does have a lower amount of material passing the No. 200 sieve; and, yet, it has a higher amount passing the Nos. 30,50 , and 100 sieves. Optimum asphalt contents vary greatly between the conventional mixture and the recycled mixtures; the conventional mixture required 5.4 percent asphalt, while the recycled mixtures required 6.6 percent when $\mathrm{AC}-5$ was used and 7.0 percent when the recycling agent was used. This variation in asphalt content was due to the fact that the compactibility of the various mixtures was different as reflected by significant differences in unit weight between the three mixtures.

Table 7 is a summary of the mix designs conducted for the three mixtures representing the material from Interstate 55 . The aggregate gradation of the three mixtures is very similar; however, the amount of material passing the No. 200 sieve is slightly higher for the recycled mixture containing the recycling agent than for the other two mixtures. The test properties such as stability, flow, unit weight, voids total mix and voids filled with asphalt are similar for the three mixtures. The optimum asphalt content for the recycled mixture containing recycling agent 
TABLE 6.--Mix Designs for Material from Lajes Air Force Base

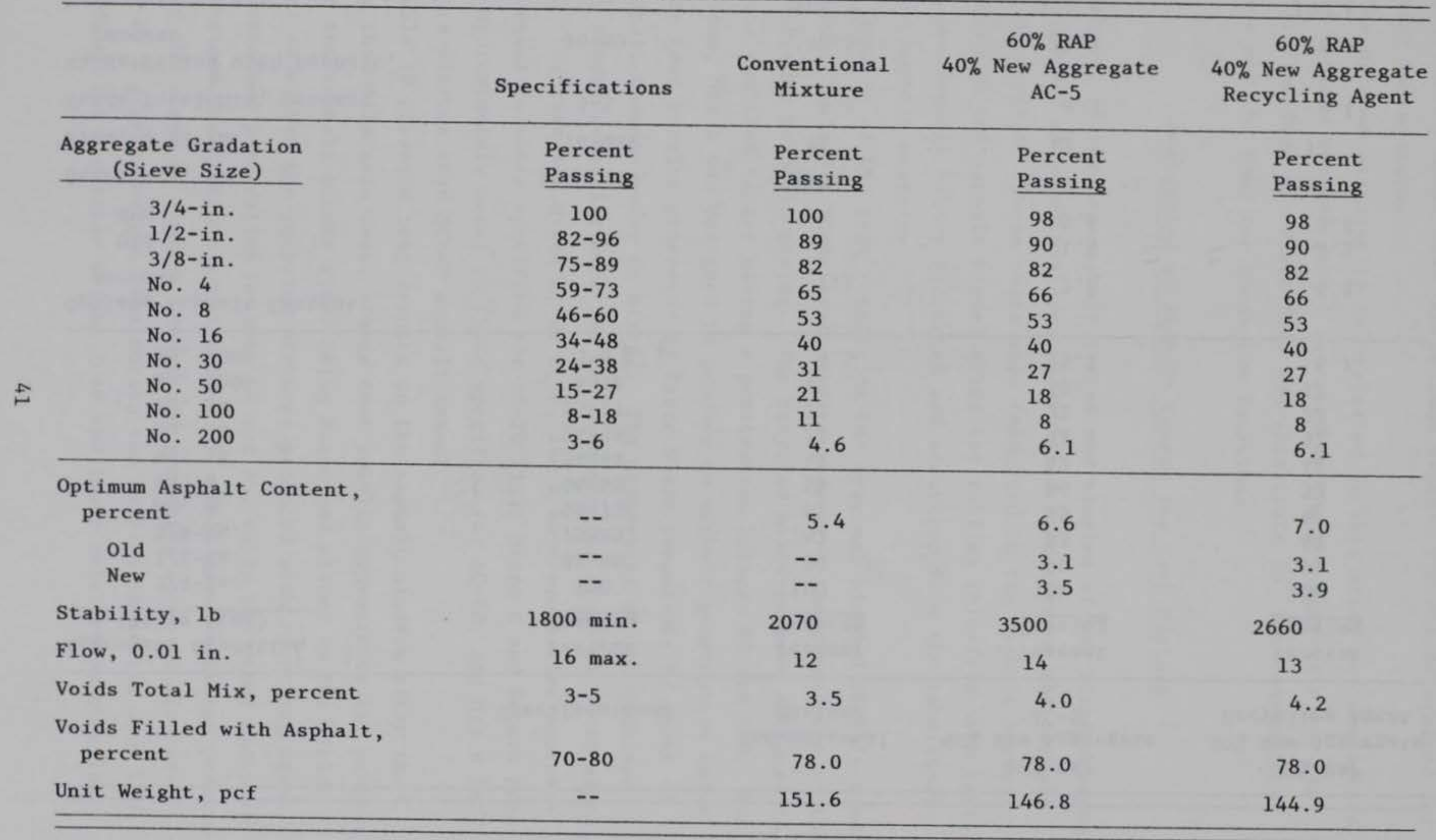


TABLE 7.--Mix Designs for Material from Interstate 55

\begin{tabular}{|c|c|c|c|c|}
\hline & Specifications & $\begin{array}{c}\text { Conventional } \\
\text { Mixture }\end{array}$ & $\begin{array}{c}40 \% \text { RAP } \\
60 \% \text { New Aggregate } \\
\text { AC-5 }\end{array}$ & $\begin{array}{c}70 \% \text { RAP } \\
\text { 30\% New Aggregate } \\
\text { Recycling Agent }\end{array}$ \\
\hline $\begin{array}{c}\text { Aggregate Gradation } \\
\text { (Sieve Size) } \\
\end{array}$ & $\begin{array}{l}\text { Percent } \\
\text { Passing }\end{array}$ & $\begin{array}{l}\text { Percent } \\
\text { Passing }\end{array}$ & $\begin{array}{l}\text { Percent } \\
\text { Passing }\end{array}$ & $\begin{array}{l}\text { Percent } \\
\text { Passing } \\
\end{array}$ \\
\hline $\begin{array}{l}\text { 3/4-in. } \\
\text { 1/2-in. } \\
\text { 3/8-in. } \\
\text { No. } 4 \\
\text { No. } 8 \\
\text { No. } 16 \\
\text { No. } 30 \\
\text { No. } 50 \\
\text { No. } 100 \\
\text { No. } 200\end{array}$ & $\begin{array}{c}100 \\
82-96 \\
75-89 \\
59-73 \\
46-60 \\
34-48 \\
24-38 \\
15-27 \\
8-18 \\
3-6\end{array}$ & $\begin{array}{r}100 \\
90 \\
82 \\
65 \\
54 \\
42 \\
32 \\
23 \\
12 \\
4.5\end{array}$ & $\begin{array}{r}100 \\
90 \\
83 \\
65 \\
54 \\
42 \\
32 \\
21 \\
10 \\
5.2\end{array}$ & $\begin{array}{r}100 \\
91 \\
83 \\
67 \\
53 \\
42 \\
32 \\
22 \\
11 \\
6.7\end{array}$ \\
\hline $\begin{array}{l}\text { Optimum Asphalt Content, } \\
\text { percent }\end{array}$ & -- & 7.1 & 7.0 & 6.3 \\
\hline $\begin{array}{l}\text { 01d } \\
\text { New }\end{array}$ & -- & -- & $\begin{array}{l}1.4 \\
5.6\end{array}$ & $\begin{array}{l}2.5 \\
3.8\end{array}$ \\
\hline Stability, lb & $1800 \mathrm{~min}$. & 2140 & 2310 & 2440 \\
\hline Flow, 0.01 in. & $16 \max$. & 12 & 13 & 12 \\
\hline Voids Total Mix, percent & $3-5$ & 4.2 & 4.3 & 4.1 \\
\hline $\begin{array}{l}\text { Voids Filled with Asphalt, } \\
\text { percent }\end{array}$ & $70-80$ & 78.0 & 78.0 & 76.0 \\
\hline Unit Weight, pcf & -- & 142.2 & 141.8 & 142.8 \\
\hline
\end{tabular}


is significantly lower than the optimum asphalt content determined for the other two mixtures.

The optimum mixtures to be evaluated in this study are summarized in Table 8. Since crushed gravel was used as the new aggregate for the material from Pope Air Force Base and Interstate 55, the conventional mixtures are the same for these two locations.

\section{Evaluation of Asphalt Cement for Each Mixture}

Samples of the new asphalt cement and samples of the blended asphalt cement for the recycled mixtures were tested to determine the asphalt cement properties. These tests were conducted on the asphalt binder initially, on the asphalt binder after the rolling thin-film oven test, and on the asphalt binder extracted and recovered from the laboratory prepared asphalt mixtures.

A summary of the test results on the original blended asphalt binder is shown in Table 9. These test results represent the properties of the blended binder prior to mixing. The recycled mixtures were designed to produce a combined binder having a penetration between 60 and 100 . For comparison, Mix B was designed to produce an asphalt penetration below 60. The test results presented in Table 9 are comparable to those of new asphalt cements prior to mixing. The properties of the combined asphalt binder generally meet the requirements for $\mathrm{AC}-20$ or $\mathrm{AC}-40$ asphalt cement. For example, Mixes A, D, E, F, and $H$ have properties approximately equal to those specified for AC-20 (13), Mixes $C$ and $G$ have properties approximately equal to those specified for $\mathrm{AC}-40$, and Mix B is much more viscous than $\mathrm{AC}-40$ asphalt cement.

Table 10 presents test results on the asphalt binders after the rolling thin-film oven test. These test results approximate the properties of the asphalt binder after being mixed and placed in the field. The data show that the recycled mixtures produced with recycling agent have a retained penetration between 40 and 45 , while the other mixtures have retained penetrations greater than 55 . This lower retained penetration for the blend of asphalt cement and recycling agent is also reflected by a greater weight loss during the rolling thin-film oven test. The tendency for a greater weight loss and lower retained penetration 
TABLE 8.--Identification of Mixes Evaluated

in this Study

Mix

Identification

Description

A

B

C

D

E

F

G

$\mathrm{H}$
100 percent new limestone aggregate with

5.4 percent $\mathrm{AC}-20$ asphalt binder

40 percent new limestone aggregate and 60 percent reclaimed asphalt pavement from Lajes Air Force Base with 3.5 percent $A C-5$ asphalt binder added

40 percent new limestone aggregate and 60 percent reclaimed asphalt pavement from Lajes Air Force Base with 3.9 percent recycling agent added

60 percent new crushed gravel and 40 percent reclaimed asphalt pavement from Pope Air Force Base with 5.1 percent $\mathrm{AC}-5$ asphalt binder added

100 percent new crushed gravel with 7.1 percent $\mathrm{AC}-20$ asphalt binder

30 percent new crushed gravel and 70 percent reclaimed asphalt pavement from Pope Air Force Base with 2.6 percent recycling agent added

60 percent new crushed gravel and 40 percent reclaimed asphalt pavement from Interstate 55 with 5.6 percent $\mathrm{AC}-5$ asphalt binder added

30 percent new crushed gravel and 70 percent reclaimed asphalt pavement from Interstate 55 with 3.8 percent recycling agent added 
TABLE 9.--Tests on Original Blended Asphalt Binder*

\begin{tabular}{|c|c|c|c|c|c|c|c|c|}
\hline Property & $\begin{array}{l}\text { Mix } \\
\text { A }\end{array}$ & $\underset{B}{\operatorname{Mix}}$ & $\underset{\mathrm{C}}{\operatorname{Mix}}$ & $\underset{D}{\operatorname{Mix}}$ & 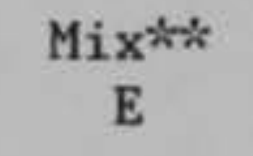 & $\underset{\mathrm{F}}{\operatorname{Mix}}$ & $\underset{G}{\operatorname{Mix}}$ & $\underset{H}{\operatorname{Mix}}$ \\
\hline Specific gravity & 1.028 & 1.045 & 1.049 & 1.034 & 1.028 & 1.038 & 1.034 & 1.032 \\
\hline Softening point, ${ }^{\circ} \mathrm{C}$ & 51 & 65 & 52 & 51 & 51 & 49 & 56 & 50 \\
\hline Viscosity $\left(140^{\circ} \mathrm{F}\right), \mathrm{P}$ & 2650 & 23000 & 3620 & 2810 & 2650 & 1490 & 5160 & 1600 \\
\hline Viscosity $\left(225^{\circ} \mathrm{F}\right)$, Cst & 2690 & 7380 & 2480 & 2220 & 2690 & 1300 & 3140 & 1330 \\
\hline Viscosity $\left(275^{\circ} \mathrm{F}\right)$, Cst & 457 & 1140 & 384 & 439 & 457 & 254 & 564 & 280 \\
\hline Penetration $\left(77^{\circ} \mathrm{F}, 100 \mathrm{~g}, 5 \mathrm{~s}\right), 0.1 \mathrm{~mm}$ & 81 & 35 & 62 & 75 & 81 & 97 & 69 & 91 \\
\hline Penetration $\left(40^{\circ} \mathrm{F}, 100 \mathrm{~g}, 5 \mathrm{~s}\right), 0.1 \mathrm{~mm}$ & 9 & 7 & 9 & 14 & 9 & 13 & 15 & 10 \\
\hline Penetration $\left(40^{\circ} \mathrm{F}, 200 \mathrm{~g}, 60 \mathrm{~s}\right), 0.1 \mathrm{~mm}$ & 42 & 23 & 31 & 44 & 42 & 56 & 37 & 38 \\
\hline Ductility $\left(77^{\circ} \mathrm{F}, 5 \mathrm{~cm} / \mathrm{min}\right), \mathrm{cm}$ & $150+$ & 26 & $150+$ & $150+$ & $150+$ & $150+$ & $150+$ & $150+$ \\
\hline Ductility $\left(40^{\circ} \mathrm{F}, 1 \mathrm{~cm} / \mathrm{min}\right), \mathrm{cm}$ & 11 & 4 & 12 & 13 & 11 & 8 & 6 & 12 \\
\hline
\end{tabular}

* Descriptions of Mixes A-H are provided in Table 8 .

t* Tests on $\mathrm{AC}-20$ asphalt cement. 
TABLE 10.--Tests on Blended Asphalt Binder after Rolling Thin-Film Oven Test*

\begin{tabular}{|c|c|c|c|c|c|c|c|c|}
\hline Property & $\underset{\mathrm{A}}{\operatorname{Mix}}$ & $\underset{B}{\operatorname{Mix}}$ & $\underset{\mathrm{C}}{\operatorname{Mix}}$ & $\underset{\mathrm{D}}{\operatorname{Mix}}$ & $\underset{\mathrm{E}}{\operatorname{Mix}}$ & $\underset{F}{\operatorname{Mix}}$ & $\underset{G}{\operatorname{Mix}}$ & $\underset{H}{\operatorname{Mix}}$ \\
\hline Weight loss, percent & 0.16 & 0.88 & 1.26 & 0.65 & 0.16 & 1.22 & 0.49 & 1.04 \\
\hline Viscosity $\left(140^{\circ} \mathrm{F}\right), \mathrm{P}$ & 8410 & 163000 & 19700 & 12200 & 8410 & 4780 & 31900 & 5180 \\
\hline Viscosity $\left(225^{\circ} \mathrm{F}\right)$, Cst & 4480 & 21400 & 5280 & 4430 & 4480 & 2350 & 8640 & 2550 \\
\hline Viscosity $\left(275^{\circ} \mathrm{F}\right)$, Cst & 700 & 2400 & 807 & 758 & 700 & 461 & 1190 & 443 \\
\hline Penetration $\left(77^{\circ} \mathrm{F}, 100 \mathrm{~g}, 5 \mathrm{~s}\right), 0.1 \mathrm{~mm}$ & 46 & 24 & 25 & 48 & 46 & 43 & 40 & 41 \\
\hline Penetration $\left(40^{\circ} \mathrm{F}, 100 \mathrm{~g}, 5 \mathrm{~s}\right), 0.1 \mathrm{~mm}$ & 9 & 6 & 7 & 10 & 9 & 8 & 10 & 8 \\
\hline Penetration $\left(40^{\circ} \mathrm{F}, 200 \mathrm{~g}, 60 \mathrm{~s}\right), 0.1 \mathrm{~mm}$ & 24 & 18 & 18 & 30 & 24 & 22 & 31 & 21 \\
\hline Ductility $\left(77^{\circ} \mathrm{F}, 5 \mathrm{~cm} / \mathrm{min}\right), \mathrm{cm}$ & 114 & 7 & 23 & 46 & 114 & $150+$ & 17 & $150+$ \\
\hline Ductility $\left(40^{\circ} \mathrm{F}, 1 \mathrm{~cm} / \mathrm{min}\right), \mathrm{cm}$ & 3 & 2 & 0 & 4 & 3 & 4 & 3 & 4 \\
\hline Retained penetration, percent & 56.8 & 68.6 & 40.3 & 64.0 & 56.8 & 44.3 & 58.0 & 45.0 \\
\hline
\end{tabular}

* Descriptions of Mixes A-H are provided in Table 8 . 
for recycled mixtures with recycling agent indicates a reduction in durability for these mixtures.

Test results on the asphalt binder extracted and recovered from the asphalt concrete beams used for the fatigue tests are shown in Table 11 . These test results also approximate the property of the binders after being placed in the field. The test results shown in Tables 10 and 11 are similar, indicating that the rolling thin-film oven test modifies the properties of the asphalt binder approximately the same as preparation of the asphalt concrete samples in the laboratory.

\section{Asphalt Mixture Test Results}

The recycled and conventional asphalt concrete mixtures were tested to evaluate the following properties:

1. Marshall stability before and after water conditioning.

2. Indirect tensile strength before and after water conditioning.

3. Resilient modulus.

4. Controlled stress flexural fatigue resistance.

Marsha11 Stability Test

Results of stability tests conducted on the mixtures after soaking in water for 30 minutes, after water soaking for 24 hours, and after vacuum saturating and water soaking for 24 hours are shown in Table 12 . Seven of the eight mixtures met the Corps of Engineers requirement of $1800-1 \mathrm{~b}(817 \mathrm{~kg}$ ) minimum stability (Tables 5, 6, and 7). Mix F had a stability of $1785 \mathrm{lb}(810 \mathrm{~kg})$. Each mixture prepared for the water susceptibility test generally had approximately the same stability as that measured during the mixture design (Table 12); however, the results for Mix $\mathrm{H}$ did show a large deviation from the mixture design test results. The asphalt recovered from the RAP used to prepare Mix $H$ had a penetration of 4 and the recovered asphalt content was only 3.5 percent. The low asphalt content and low asphalt penetration in the RAP and the high percentage of RAP used to prepare Mix H (70 percent) made it difficult to properly blend this recycled mixture in the laboratory, which probably led to a highly variable mixture. The high variability between the samples of Mix H prepared for water susceptibility testing as shown in Table 12 supports this. 
TABLE 11.--Tests on Asphalt Binder Recovered from Asphalt Concrete Beams Used for Fatigue Tests*

\begin{tabular}{lrrrrrrrrr}
\hline \multicolumn{1}{c}{ Property } & $\begin{array}{c}\text { Mix } \\
\text { A }\end{array}$ & $\begin{array}{c}\text { Mix } \\
\text { B }\end{array}$ & $\begin{array}{c}\text { Mix } \\
\text { C }\end{array}$ & $\begin{array}{c}\text { Mix } \\
\text { D }\end{array}$ & $\begin{array}{c}\text { Mix } \\
\text { E }\end{array}$ & $\begin{array}{c}\text { Mix } \\
\mathrm{F}\end{array}$ & $\begin{array}{c}\text { Mix } \\
\mathrm{G}\end{array}$ & $\begin{array}{c}\text { Mix } \\
\mathrm{H}\end{array}$ \\
\hline Specific gravity & 1.036 & 1.052 & 1.038 & 1.042 & 1.037 & 1.039 & 1.048 & 1.038 \\
Softening point, ${ }^{\circ} \mathrm{C}$ & 59 & 69 & 60 & 58 & 61 & 53 & 65 & 54 \\
Viscosity $\left(140^{\circ} \mathrm{F}\right), \mathrm{P}$ & 11500 & 75600 & 9650 & 9800 & 24200 & 2220 & 24100 & 3970 \\
Viscosity $\left(225^{\circ} \mathrm{F}\right), \mathrm{Cst}$ & 5000 & 15200 & 3130 & 3900 & 6650 & 1690 & 6720 & 2140 \\
Viscosity $\left(275^{\circ} \mathrm{F}\right), \mathrm{Cst}$ & 746 & 1630 & 548 & 642 & 1040 & 312 & 1060 & 396 \\
Penetration $\left(77^{\circ} \mathrm{F}, 100 \mathrm{~g}, 5 \mathrm{~s}\right), 0.1 \mathrm{~mm}$ & 32 & 18 & 30 & 59 & 41 & 68 & 48 & 51 \\
Penetration $\left(40^{\circ} \mathrm{F}, 100 \mathrm{~g}, 5 \mathrm{~s}\right), 0.1 \mathrm{~mm}$ & 3 & 2 & 5 & 13 & 9 & 10 & 12 \\
Penetration $\left(40^{\circ} \mathrm{F}, 200 \mathrm{~g}, 60 \mathrm{~s}\right), 0.1 \mathrm{~mm}$ & 22 & 16 & 18 & 34 & 25 & 29 & 31 \\
Ductility $\left(77^{\circ} \mathrm{F}, 5 \mathrm{~cm} / \mathrm{min}\right), \mathrm{cm}$ & $130+$ & 14 & 69 & 143 & 70 & $150+$ & 30 & $150+$ \\
Ductility $\left(40^{\circ} \mathrm{F}, 1 \mathrm{~cm} / \mathrm{min}\right), \mathrm{cm}$ & 6 & 3 & 4 & 6 & 5 & 5 & 4
\end{tabular}

* Descriptions of Mixes A-H are provided in Table 8 . 
TABLE 12.--Marshall Stability Before and After Water Soaking

\begin{tabular}{|c|c|c|c|c|c|c|}
\hline \multirow[b]{2}{*}{$\begin{array}{l}\text { Mix } \\
\text { Identification* }\end{array}$} & \multirow[b]{2}{*}{$\begin{array}{l}\text { Sample } \\
\text { No. }\end{array}$} & \multirow{2}{*}{$\begin{array}{l}\text { Marshall } \\
\text { Stability } \\
\text { Ib }\end{array}$} & \multicolumn{2}{|c|}{$\begin{array}{l}\text { Marshall Stability After } \\
24-h r \text { Immersion } \\
\end{array}$} & \multicolumn{2}{|c|}{$\begin{array}{c}\text { Marshall Stability After } \\
\text { Vacuum Saturation and } \\
24-\mathrm{hr} \text { Immersion } \\
\end{array}$} \\
\hline & & & Pounds & $\begin{array}{l}\text { Percent of } \\
\text { Original }\end{array}$ & Pounds & $\begin{array}{l}\text { Percent of } \\
\text { Original }\end{array}$ \\
\hline \multirow[t]{2}{*}{ A } & $\begin{array}{l}1 \\
2 \\
3\end{array}$ & $\begin{array}{l}2046 \\
2092 \\
2367 \\
\end{array}$ & $\begin{array}{l}2328 \\
2166 \\
2367 \\
\end{array}$ & & $\begin{array}{l}2166 \\
1783 \\
2067 \\
\end{array}$ & \\
\hline & Average & 2168 & 2287 & 105.5 & 2005 & 92.5 \\
\hline \multirow[t]{2}{*}{ B } & $\begin{array}{l}1 \\
2 \\
3\end{array}$ & $\begin{array}{l}3200 \\
2912 \\
3350 \\
\end{array}$ & $\begin{array}{l}2862 \\
2917 \\
2850 \\
\end{array}$ & & $\begin{array}{l}3467 \\
2725 \\
2575 \\
\end{array}$ & \\
\hline & Average & 3154 & 2876 & 91.2 & 2922 & 92.6 \\
\hline \multirow[t]{2}{*}{ C } & $\begin{array}{l}1 \\
2 \\
3\end{array}$ & $\begin{array}{l}2400 \\
2900 \\
2472 \\
\end{array}$ & $\begin{array}{l}2633 \\
2220 \\
2032 \\
\end{array}$ & & $\begin{array}{l}2588 \\
2328 \\
2582 \\
\end{array}$ & \\
\hline & Average & 2591 & 2295 & 88.6 & 2481 & 95.8 \\
\hline \multirow[t]{2}{*}{ D } & $\begin{array}{l}1 \\
2 \\
3\end{array}$ & $\begin{array}{l}2057 \\
2256 \\
2186 \\
\end{array}$ & $\begin{array}{l}1895 \\
1628 \\
2162 \\
\end{array}$ & & $\begin{array}{l}763 \\
893 \\
884 \\
\end{array}$ & \\
\hline & Average & 2166 & 1895 & 87.5 & 847 & 39.1 \\
\hline \multirow[t]{2}{*}{ E } & $\begin{array}{l}1 \\
2 \\
3\end{array}$ & $\begin{array}{c}1925 \\
2092 \\
-- \\
\end{array}$ & $\begin{array}{l}1535 \\
1644 \\
1587 \\
\end{array}$ & & $\begin{array}{l}559 \\
872 \\
676 \\
\end{array}$ & \\
\hline & Average & 2008 & 1589 & 79.1 & 702 & 35.0 \\
\hline \multirow[t]{2}{*}{$\mathrm{F}$} & $\begin{array}{l}1 \\
2 \\
3\end{array}$ & $\begin{array}{l}1867 \\
1912 \\
1508 \\
\end{array}$ & $\begin{array}{l}1650 \\
1612 \\
1712 \\
\end{array}$ & & $\begin{array}{l}1767 \\
1583 \\
1583 \\
\end{array}$ & \\
\hline & Average & 1726 & 1658 & 96.1 & 1644 & 95.2 \\
\hline \multirow[t]{2}{*}{ G } & $\begin{array}{l}1 \\
2 \\
3\end{array}$ & $\begin{array}{l}2096 \\
1984 \\
2124 \\
\end{array}$ & $\begin{array}{l}1440 \\
1224 \\
1604 \\
\end{array}$ & & $\begin{array}{r}787 \\
1056 \\
1040 \\
\end{array}$ & \\
\hline & Average & 2068 & 1423 & 68.8 & 961 & 46.5 \\
\hline \multirow[t]{2}{*}{ Н } & $\begin{array}{l}1 \\
2 \\
3\end{array}$ & $\begin{array}{l}1200 \\
1424 \\
2025 \\
\end{array}$ & $\begin{array}{l}1167 \\
1600 \\
1500 \\
\end{array}$ & & $\begin{array}{r}860 \\
1100 \\
1288 \\
\end{array}$ & \\
\hline & Average & 1550 & 1422 & 91.7 & 1083 & 69.9 \\
\hline
\end{tabular}

Descriptions of Mixes A-H are provided in Table 8. 
The 24-hour static immersion test results indicate that the retained stability for Mix G was 68.8 percent, which is below the 75 percent minimum recommended by the Corps of Engineers. Mix E, which has a retained stability of 79.1 percent, was barely satisfactory.

A more severe water susceptibility test which includes vacuumsaturating the samples prior to soaking for 24 hours indicates that some of the mixtures have considerably lower retained stabilities than other mixtures. For instance, the retained stabilities for Mixes E, G, and H appear to be lower than those for Mixes A, B, C, and F.

Indirect Tensile Test

The indirect tensile test was conducted on each mixture at temperatures of $77^{\circ} \mathrm{F}$ and $40^{\circ} \mathrm{F}$. The vertical load, vertical deformation, and horizontal deformation were measured during the test and used to compute the tensile strength, stiffness modulus (secant at failure), and tensile strain at failure. The computed indirect tensile strength is shown in Table 13 for each mixture at $77^{\circ} \mathrm{F}$ and in Table 14 for each mixture at $40^{\circ} \mathrm{F}$.

The tensile strain at failure is particularly important at the lower temperature as a measure of cracking that would be caused by thermal shrinkage of the asphalt concrete at these low temperatures. At $40^{\circ} \mathrm{F}$, the mixtures with the lowest tensile strength generally produced the highest tensile strain at failure.

Indirect tensile tests were conducted on samples of the eight mixtures after immersion in water for 24 hours and after vacuum saturating and soaking for 24 hours. The results of these tests are shown in Tables 15 and 16 . The effect of water is generally measured by the change in tensile strength after water conditioning the samples. The effect of water conditioning on strain to failure and stiffness modulus of the samples was also measured.

An analysis of variance was conducted on the measured tensile strength, tensile strain at failure, and stiffness modulus (secant at failure) for the eight mixtures shown in Tables 13 and 14 to determine if the mixture type had a significant effect on the measured test results. At $77^{\circ} \mathrm{F}$, the critical $\mathrm{F}$ values for strength, strain, and stiffness modulus were $4.28(\alpha=0.05)$ in all three cases, while the computed F values were $22.22,5.30$, and 12.95 , respectively. At $40^{\circ} \mathrm{F}$, the critical 
TABLE 13.--Tensile Strength, Stiffness Modulus (Secant at Failure), and Failure Strain Obtained from Indirect Tensile Test at $77^{\circ} \mathrm{F}$

\begin{tabular}{|c|c|c|c|c|}
\hline $\begin{array}{l}\text { Mix* } \\
\text { Identification }\end{array}$ & $\begin{array}{c}\text { Sample } \\
\text { No. }\end{array}$ & $\begin{array}{l}\text { Tensile } \\
\text { Strength } \\
\quad \text { psi }\end{array}$ & $\begin{array}{c}\text { Strain at } \\
\text { Failure } \\
\text { in./in. }\end{array}$ & $\begin{array}{l}\text { Stiffness } \\
\text { Modulus } \\
\text { psi }\end{array}$ \\
\hline \multirow[t]{4}{*}{ A } & 1 & -- & -- & -- \\
\hline & 2 & 115.0 & 0.0051 & 22,400 \\
\hline & 3 & 114.5 & 0.0051 & 22,300 \\
\hline & Average & 114.8 & 0.0051 & 23,500 \\
\hline \multirow[t]{4}{*}{ B } & 1 & 99.5 & 0.0026 & 38,800 \\
\hline & 2 & 90.4 & 0.0015 & 58,700 \\
\hline & 3 & 104.0 & 0.0021 & $\underline{50,700}$ \\
\hline & Average & 98.0 & 0.0021 & 49,400 \\
\hline \multirow[t]{4}{*}{ C } & 1 & 48.5 & 0.0051 & 9,500 \\
\hline & 2 & 44.4 & 0.0056 & 7,900 \\
\hline & 3 & $\underline{45.0}$ & $\underline{0.0036}$ & $\underline{12,500}$ \\
\hline & Average & 46.0 & 0.0048 & 10,000 \\
\hline \multirow[t]{4}{*}{ D } & 1 & 69.7 & 0.0062 & 11,300 \\
\hline & 2 & 100.0 & 0.0051 & 19,500 \\
\hline & 3 & 102.9 & $\underline{0.0046}$ & 22,300 \\
\hline & Average & 90.9 & 0.0053 & 17,700 \\
\hline \multirow[t]{4}{*}{ E } & 1 & 133.7 & 0.0051 & 26,100 \\
\hline & 2 & 135.1 & 0.0051 & 26,300 \\
\hline & 3 & 152.1 & $\underline{0.0051}$ & $\underline{29,700}$ \\
\hline & Average & 140.3 & 0.0051 & 27,400 \\
\hline \multirow[t]{4}{*}{ F } & 1 & 101.9 & 0.0051 & 19,900 \\
\hline & 2 & 98.6 & 0.0051 & 19,200 \\
\hline & 3 & 94.8 & 0.0051 & $\underline{18,500}$ \\
\hline & Average & 98.4 & 0.0051 & 19,200 \\
\hline \multirow[t]{4}{*}{ G } & 1 & 97.9 & 0.0051 & 19,100 \\
\hline & 2 & 102.6 & 0.0041 & 25,000 \\
\hline & 3 & -- & -- & $\cdots$ \\
\hline & Average & 100.1 & 0.0046 & 22,000 \\
\hline \multirow[t]{4}{*}{$\mathrm{H}$} & 1 & 93.0 & 0.0036 & 25,900 \\
\hline & 2 & 99.3 & 0.0031 & 32,300 \\
\hline & 3 & $\underline{77.0}$ & $\underline{0.0046}$ & 16,700 \\
\hline & Average & 89.8 & 0.0038 & 25,000 \\
\hline
\end{tabular}

* Descriptions of Mixes A-H are provided in Table 8. 
TABLE 14.--Tensile Strength, Stiffness Modulus (Secant at Failure), and Failure Strain Obtained from Indirect Tensile Test at $40^{\circ} \mathrm{F}$

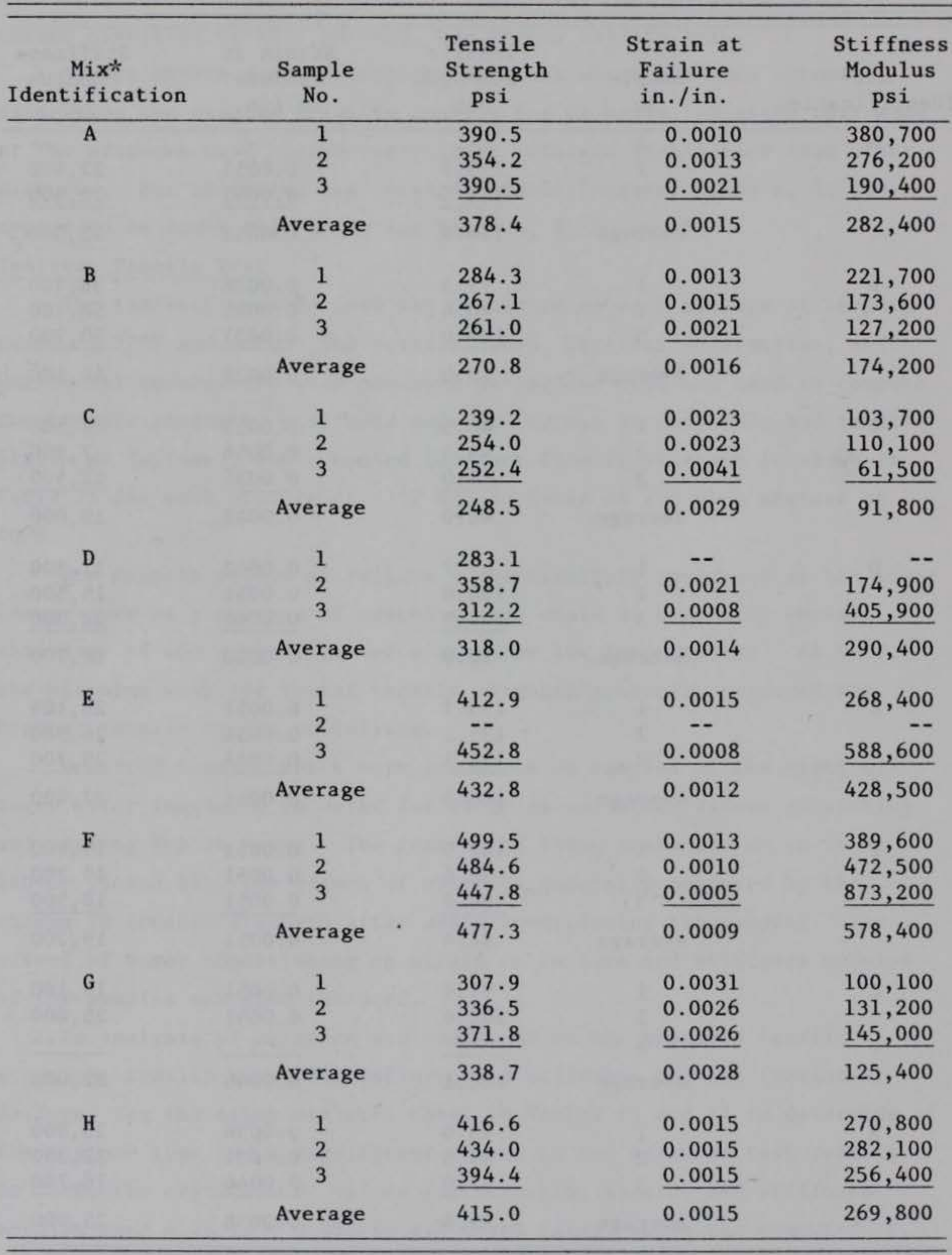

* Descriptions of Mixes A-H are provided in Table 8. 
TABLE 15.--Tensile Strength, Stiffness Modulus (Secant at Failure), and Failure Strain Obtained from Indirect Tensile Test After Soaking Samples for 24 Hours

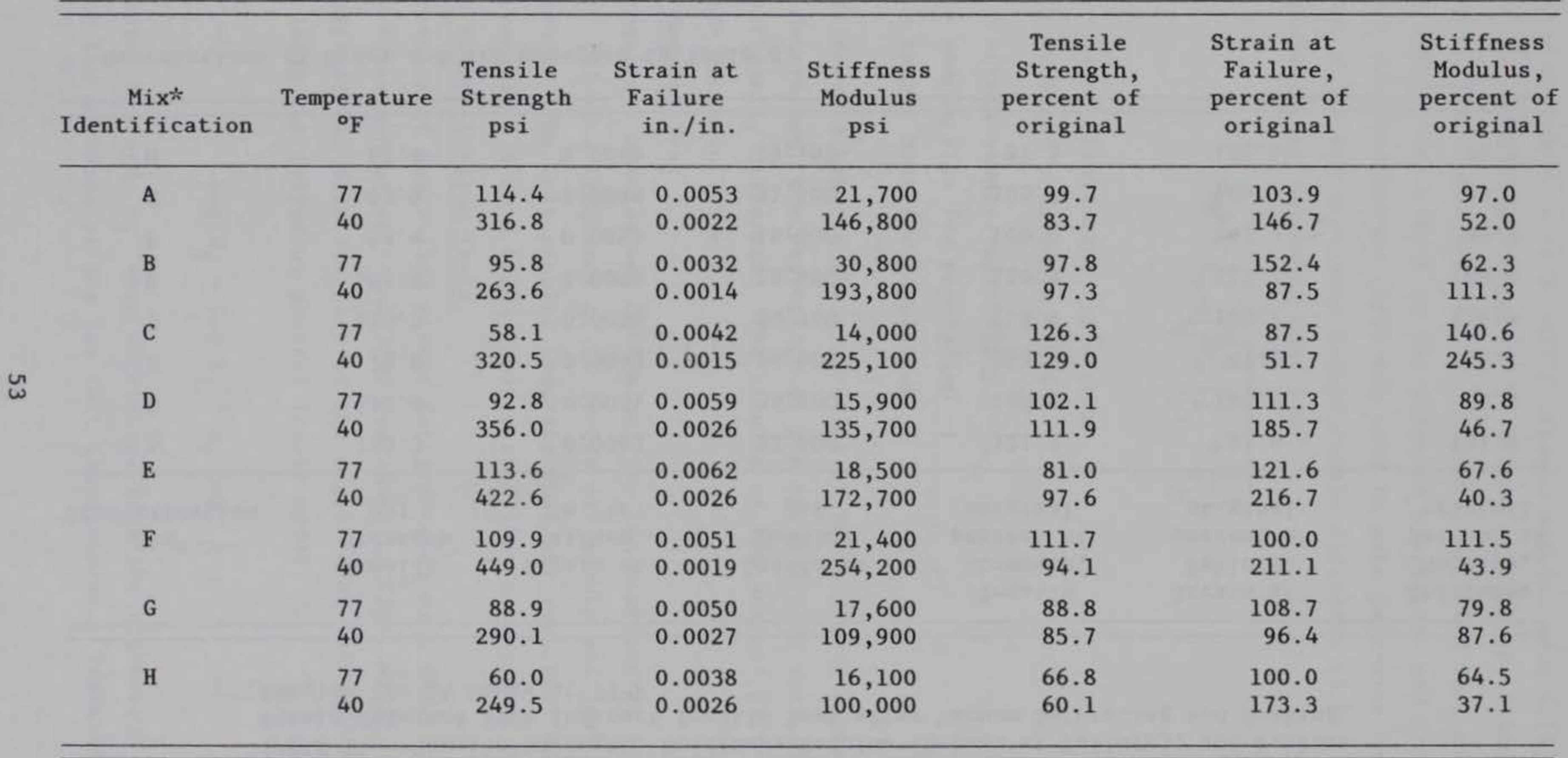

* Descriptions of Mixes A-H are provided in Table 8 . 
TABLE 16.--Tensile Strength, Stiffness Modulus (Secant at Failure), and Failure Strain Obtained from Indirect Tensile Test after Vacuum Saturating and Soaking Samples for 24 Hours at $77^{\circ} \mathrm{F}$

\begin{tabular}{|c|c|c|c|c|c|c|}
\hline A & 139.3 & 0.0062 & 22,600 & 121.3 & 121.6 & 101.0 \\
\hline B & 112.6 & 0.0031 & 36,800 & 114.9 & 147.6 & 74.5 \\
\hline D & 116.7 & 0.0056 & 20,700 & 128.4 & 105.7 & 116.9 \\
\hline E & 163.9 & 0.0058 & 28,400 & 116.8 & 113.7 & 103.8 \\
\hline F & 98.4 & 0.0053 & 18,600 & 100.0 & 103.9 & 96.9 \\
\hline G & 103.9 & 0.0049 & 21,100 & 103.8 & 106.5 & 95.7 \\
\hline H & 87.4 & 0.0046 & 19,100 & 97.3 & 121.1 & 76.5 \\
\hline
\end{tabular}

* Descriptions of Mixes A-H are provided in Table 8. 
F values for strength, strain, and stiffness modulus were $4.14,4.28$, and $4.28(\alpha=0.05)$, while the computed $F$ values were $29.98,4.40$, and 4.40 , respectively. Hence, the analysis of variance indicated that mixture type did have a significant effect on the measured properties and Fisher's least significant difference (LSD) was used to make pair-wise comparisons to determine which mixtures were significantly different (57). The LSD was determined by the following equation:

$$
\text { LSD }=t_{\alpha / 2} \sqrt{S_{w}^{2}\left(\frac{1}{n_{i}}+\frac{1}{n_{j}}\right)}
$$

where

$$
\begin{aligned}
\text { LSD } & =\text { least significant difference } \\
t_{\alpha / 2} & =\text { critical t-value }(\alpha=0.05) \\
s_{w}^{2} & =\text { within-sample variability } \\
n_{i} & =\text { sample size for population } i \\
n_{j} & =\text { sample size for population } j
\end{aligned}
$$

When the difference between the properties of two mixtures exceeded the LSD value determined, the properties of the two mixtures were determined to be significantly different. The results of the desired pair-wise comparisons are shown in Table 17.

Resilient Modulus Test

The resilient modulus was determined for the mixtures at $40^{\circ} \mathrm{F}$ and $77^{\circ} \mathrm{F}$ (Table 18) at a frequency of 20 cycles per minute and load duration of 0.1 seconds. The test results indicate that the resilient modulus at $40^{\circ} \mathrm{F}$ is generally 1.5 to 3 times greater than that measured at $77^{\circ} \mathrm{F}$.

\section{Controlled Stress Fatigue Tests}

The results of controlled stress fatigue tests as a function of stress for Mixes $\mathrm{A}-\mathrm{H}$ at $40^{\circ} \mathrm{F}$ and $77^{\circ} \mathrm{F}$ are shown in Figs. 4-11. Regression analysis of the data for each of the mixtures at $40^{\circ} \mathrm{F}$ and $77^{\circ} \mathrm{F}$ was conducted using the following general linear model:

$$
\log N_{f}=\log K_{1}+n_{1} \log \frac{1}{\sigma}
$$

The constants $K_{1}$ and $n_{1}$ were determined from the regression analysis for each of the mixtures at the two test temperatures. Table 19 is a 
TABLE 17.--Summary of Significant Differences of Mixture Properties Determined from Indirect Tensile Test $(\alpha=0.05)$

\begin{tabular}{|c|c|c|c|c|c|c|}
\hline $\begin{array}{c}\text { Mixes* } \\
\text { Compared }\end{array}$ & $\begin{array}{l}\text { Tensile } \\
\text { Strength } \\
77^{\circ} \mathrm{F}, \text { psi }\end{array}$ & $\begin{array}{l}\text { Tensile } \\
\text { Strength } \\
40^{\circ} \mathrm{F}, \mathrm{psi}\end{array}$ & $\begin{array}{c}\text { Tensile Strain } \\
77^{\circ} \mathrm{F} \\
\text { in./in. }\end{array}$ & $\begin{array}{c}\text { Tensile Strain } \\
40^{\circ} \mathrm{F} \\
\text { in./in. }\end{array}$ & $\begin{array}{l}\text { Stiffness } \\
\text { Modulus } \\
77^{\circ} \mathrm{F}, \text { psi }\end{array}$ & $\begin{array}{l}\text { Stiffness } \\
\text { Modulus } \\
40^{\circ} \mathrm{F} \text {, psi }\end{array}$ \\
\hline$A$ and $B$ & NS & $A>B$ & $A>B$ & NS & $\mathrm{B}>\mathrm{A}$ & NS \\
\hline$A$ and $C$ & $A>C$ & $A>C$ & NS & $\mathrm{C}>\mathrm{A}$ & $A>C$ & NS \\
\hline$B$ and $C$ & $B>C$ & NS & $\mathrm{C}>\mathrm{B}$ & $C>B$ & $B>C$ & NS \\
\hline$D$ and $E$ & $E>D$ & $E>D$ & NS & NS & NS & NS \\
\hline$F$ and $E$ & $E>F$ & NS & NS & NS & NS & NS \\
\hline$D$ and $F$ & NS & $F>D$ & NS & NS & NS & $\mathrm{F}>\mathrm{D}$ \\
\hline $\mathrm{E}$ and $\mathrm{G}$ & $E>G$ & $E>G$ & NS & $\mathrm{G}>\mathrm{E}$ & NS & $E>G$ \\
\hline$E$ and $H$ & $\mathrm{E}>\mathrm{H}$ & NS & NS & NS & NS & NS \\
\hline $\mathrm{H}$ and $\mathrm{G}$ & NS & $\mathrm{H}>\mathrm{G}$ & NS & $\mathrm{G}>\mathrm{H}$ & NS & NS \\
\hline$A$ and $E$ & $E>A$ & $E>A$ & NS & NS & NS & NS \\
\hline
\end{tabular}

NOTE: NS = No significant difference.

* Descriptions of Mixes A-H are provided in Table 8 . 
TABLE 18.--Resilient Modulus of Asphalt Concrete Mixtures

\begin{tabular}{|c|c|c|c|}
\hline \multirow{2}{*}{$\begin{array}{l}\text { Mix* } \\
\text { Identification }\end{array}$} & \multirow{2}{*}{$\begin{array}{c}\text { Sample } \\
\text { No. }\end{array}$} & \multicolumn{2}{|c|}{ Resilient Modulus, Ksi } \\
\hline & & $40^{\circ} \mathrm{F}$ & $77^{\circ} \mathrm{F}$ \\
\hline \multirow[t]{4}{*}{ A } & 1 & 370 & 121 \\
\hline & 2 & 354 & 133 \\
\hline & 3 & $\underline{405}$ & $\underline{100}$ \\
\hline & Average & 376 & 118 \\
\hline \multirow[t]{4}{*}{ B } & 1 & 155 & 207 \\
\hline & 2 & 250 & 101 \\
\hline & 3 & $\underline{266}$ & $\underline{120}$ \\
\hline & Average & 224 & 143 \\
\hline \multirow[t]{4}{*}{ c } & 1 & 266 & 70 \\
\hline & 2 & 104 & 56 \\
\hline & 3 & $\underline{198}$ & $\underline{62}$ \\
\hline & Average & 189 & 63 \\
\hline \multirow[t]{4}{*}{ D } & 1 & 129 & 64 \\
\hline & 2 & 118 & 73 \\
\hline & 3 & 97 & $\underline{74}$ \\
\hline & Average & 115 & 70 \\
\hline \multirow[t]{4}{*}{ E } & 1 & 142 & 101 \\
\hline & 2 & 185 & 88 \\
\hline & 3 & $\underline{112}$ & $\underline{131}$ \\
\hline & Average & 146 & 107 \\
\hline \multirow[t]{4}{*}{$\mathbf{F}$} & 1 & 177 & 87 \\
\hline & 2 & 157 & 99 \\
\hline & 3 & $\underline{212}$ & $\underline{62}$ \\
\hline & Average & 182 & 83 \\
\hline \multirow[t]{4}{*}{ G } & 1 & 189 & 74 \\
\hline & 2 & 193 & 93 \\
\hline & 3 & 118 & $\underline{100}$ \\
\hline & Average & 167 & 89 \\
\hline \multirow[t]{4}{*}{ H } & 1 & -- & 80 \\
\hline & 2 & 90 & 118 \\
\hline & 3 & $\underline{170}$ & 85 \\
\hline & Average & 130 & 94 \\
\hline
\end{tabular}

* Descriptions of Mixes A-H are provided in Table 8 . 


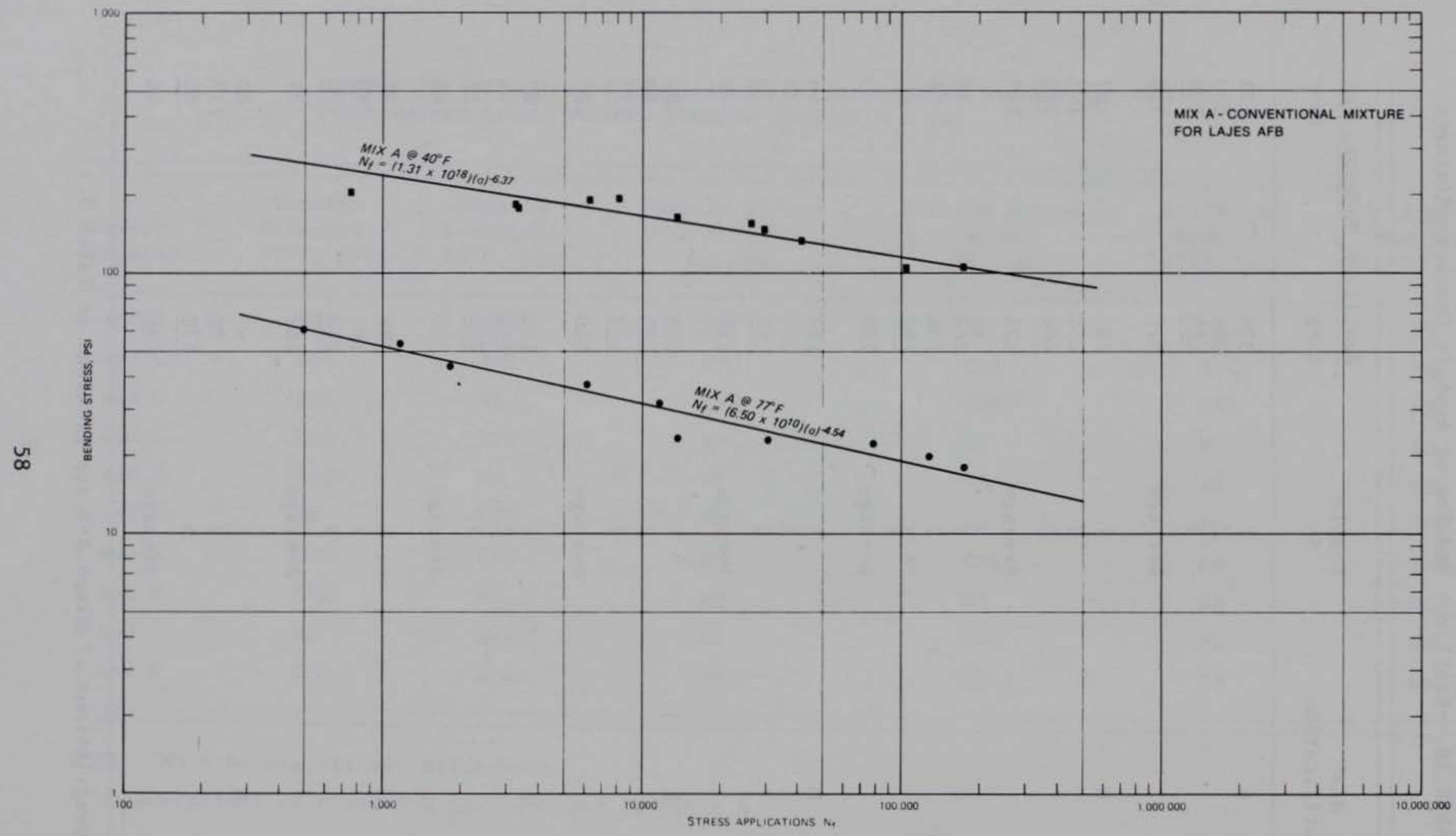

FIG. 4.--Fatigue Results for Mix $\mathrm{A}$ as a Function of Bending Stress 


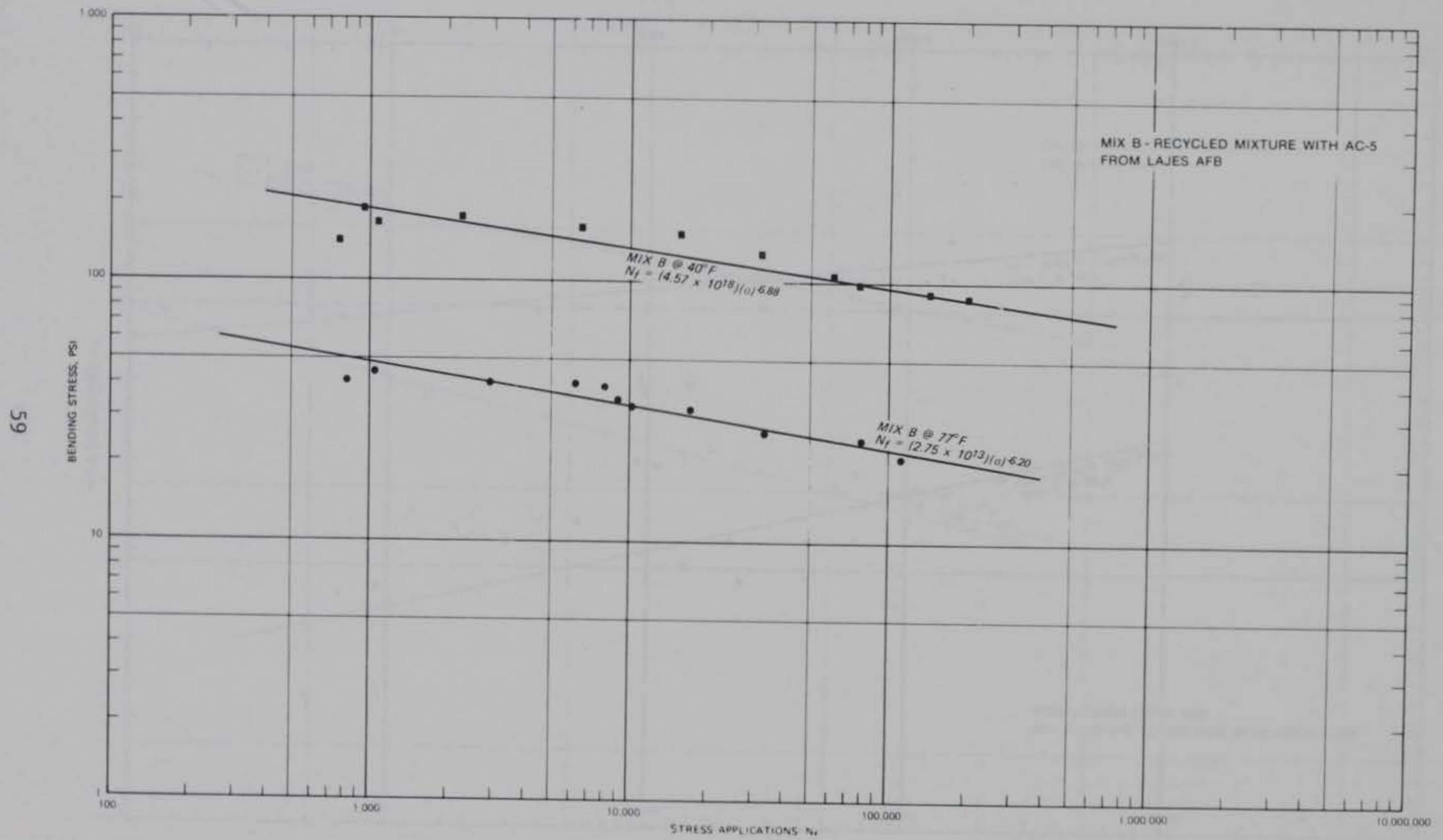

FIG. 5.--Fatigue Results for Mix B as a Function of Bending Stress 


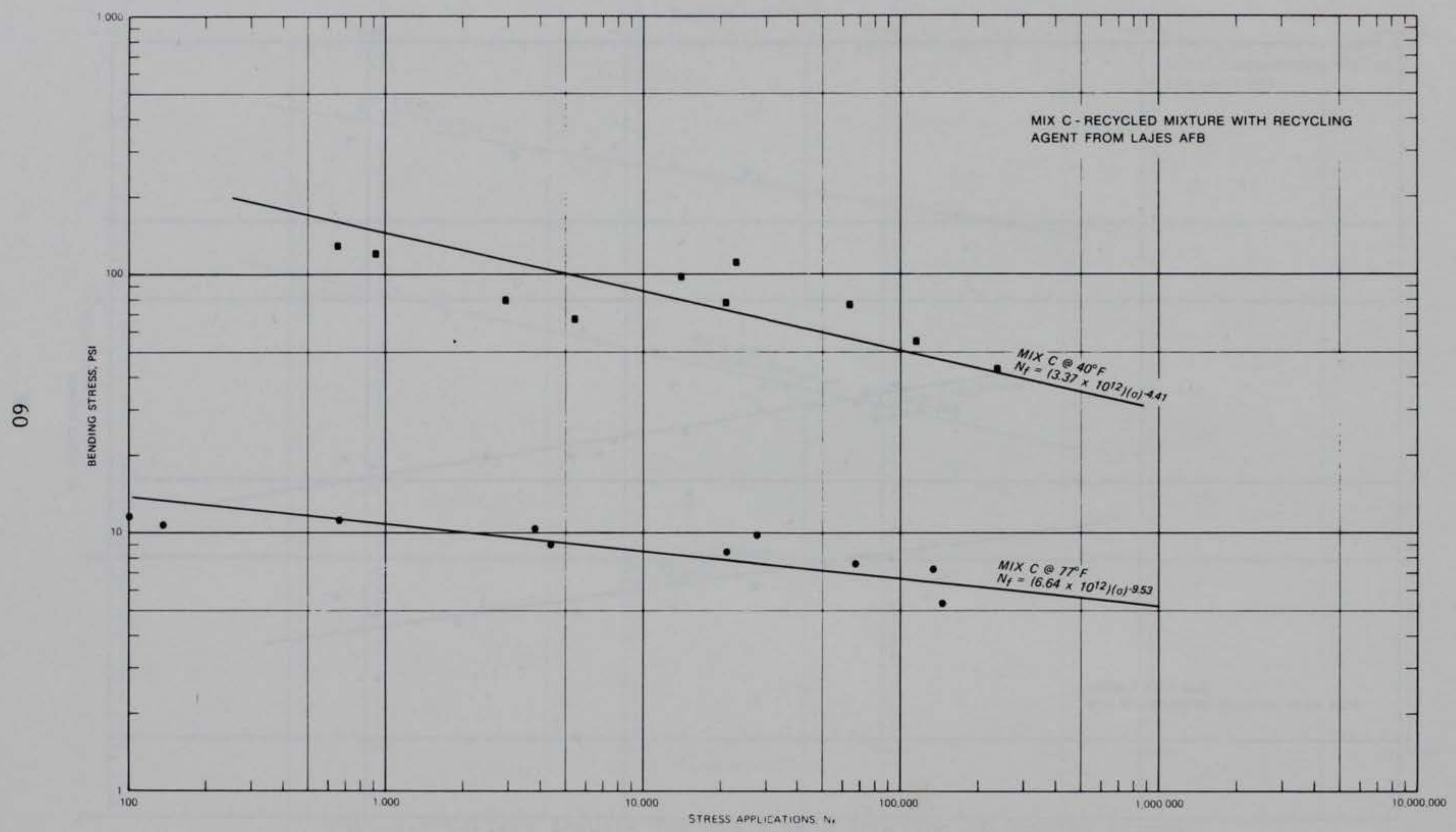

FIG. 6.--Fatigue Results for Mix C as a Function of Bending Stress 


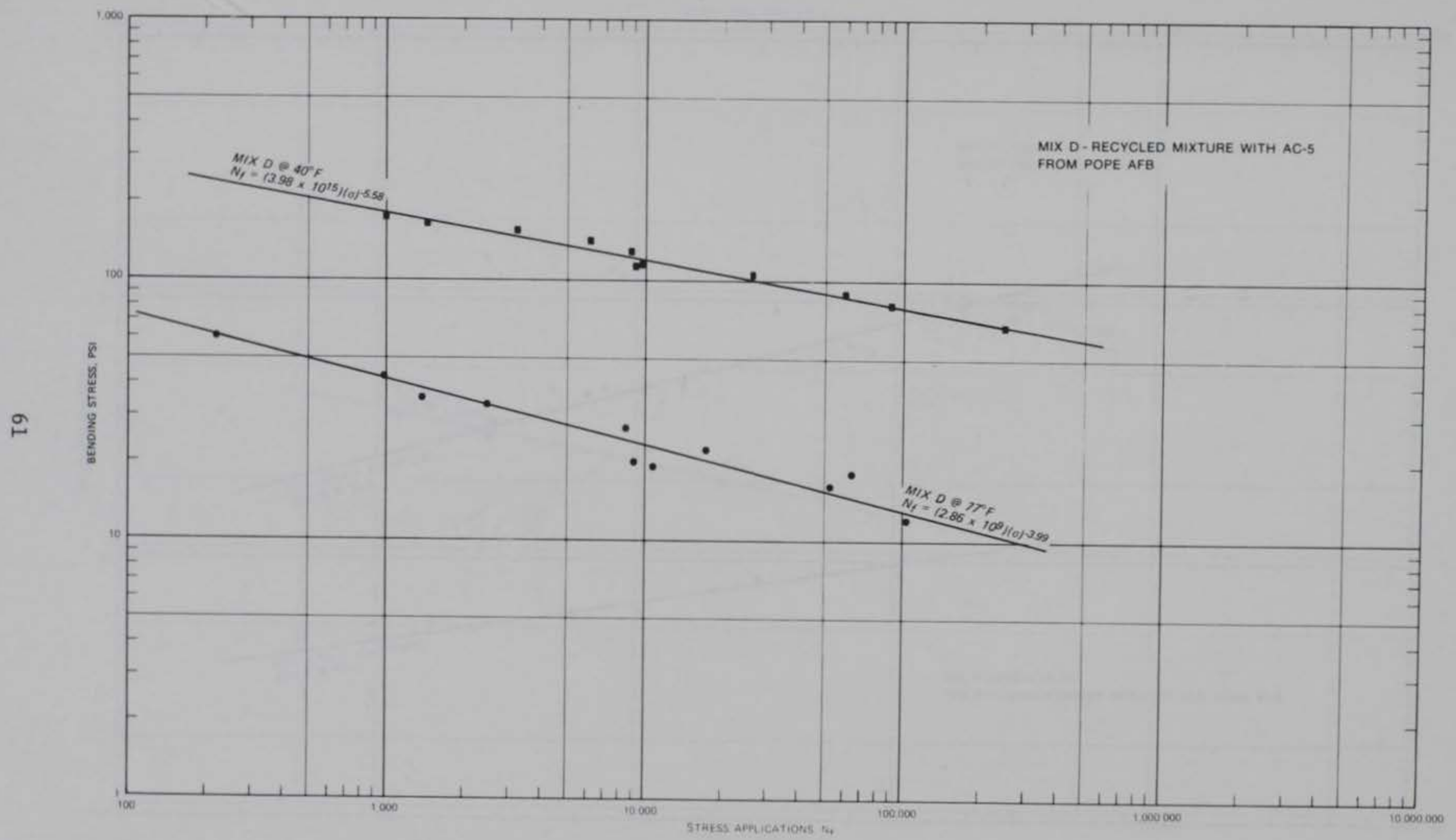

FIG. 7.--Fatigue Results for Mix D as a Function of Bending Stress 


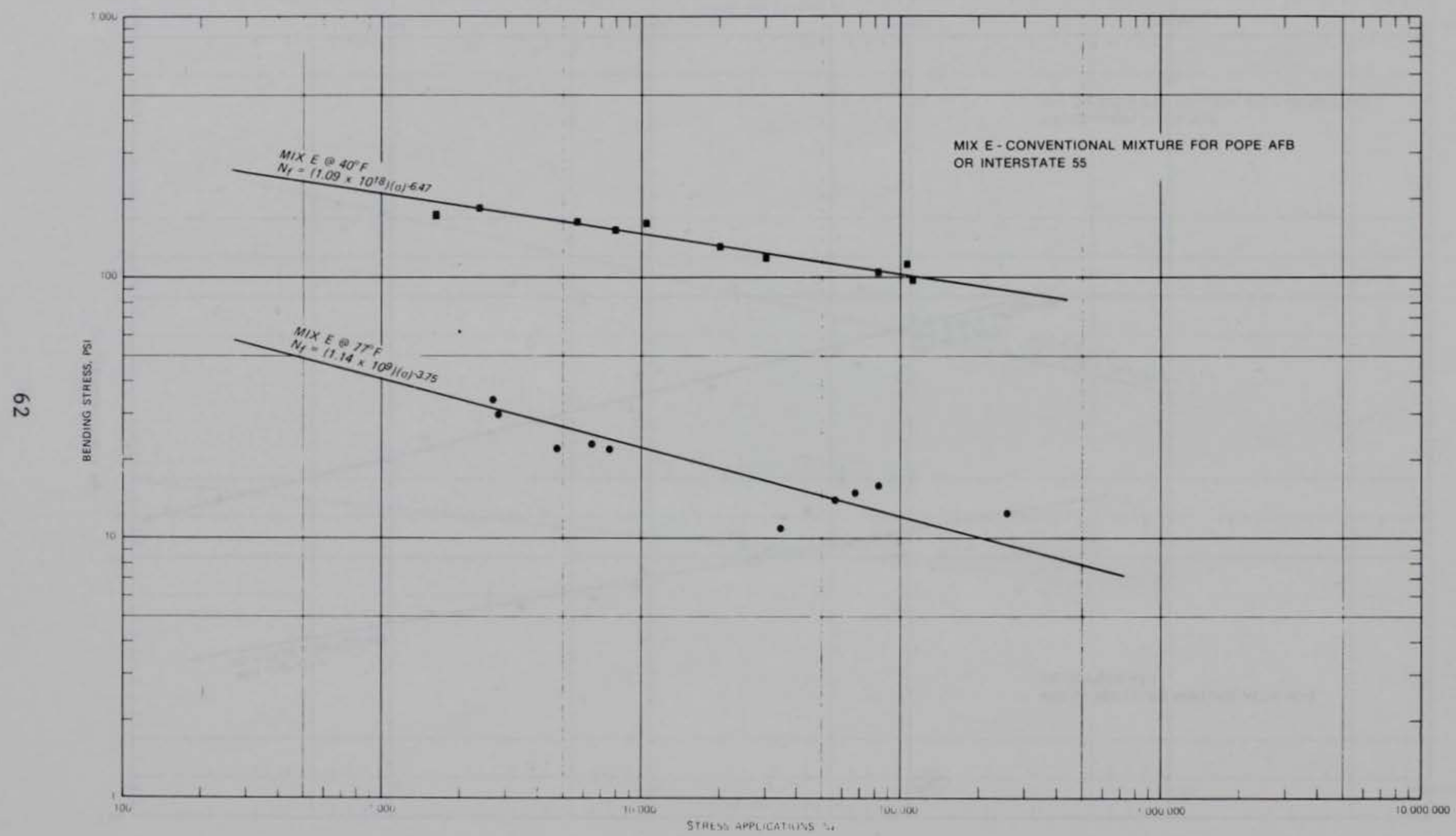

FIG. 8.--Fatigue Results for Mix E as a Function of Bending Stress 


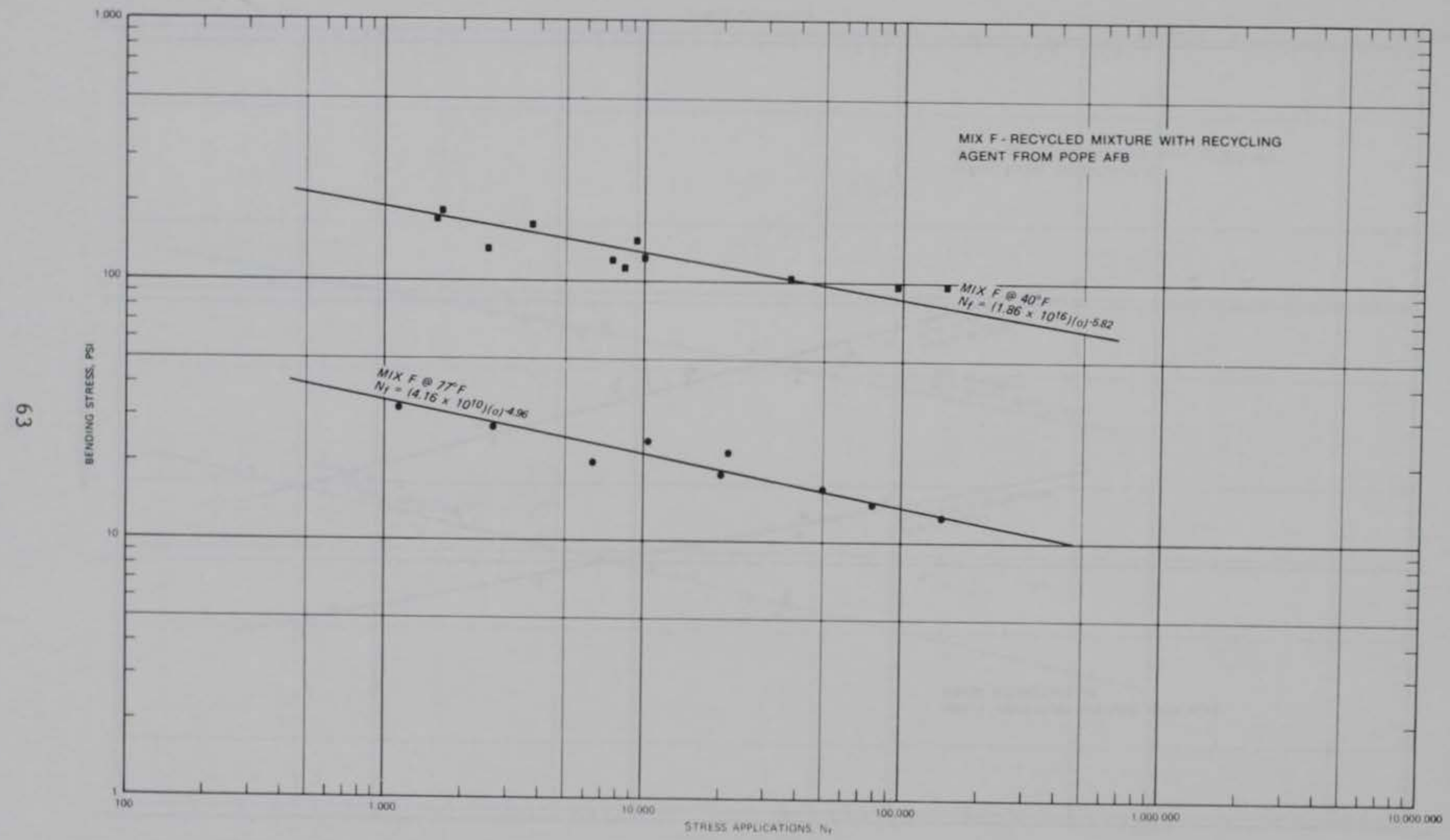

FIG. 9. --Fatigue Results for Mix $\mathrm{F}$ as a Function of Bending Stress 


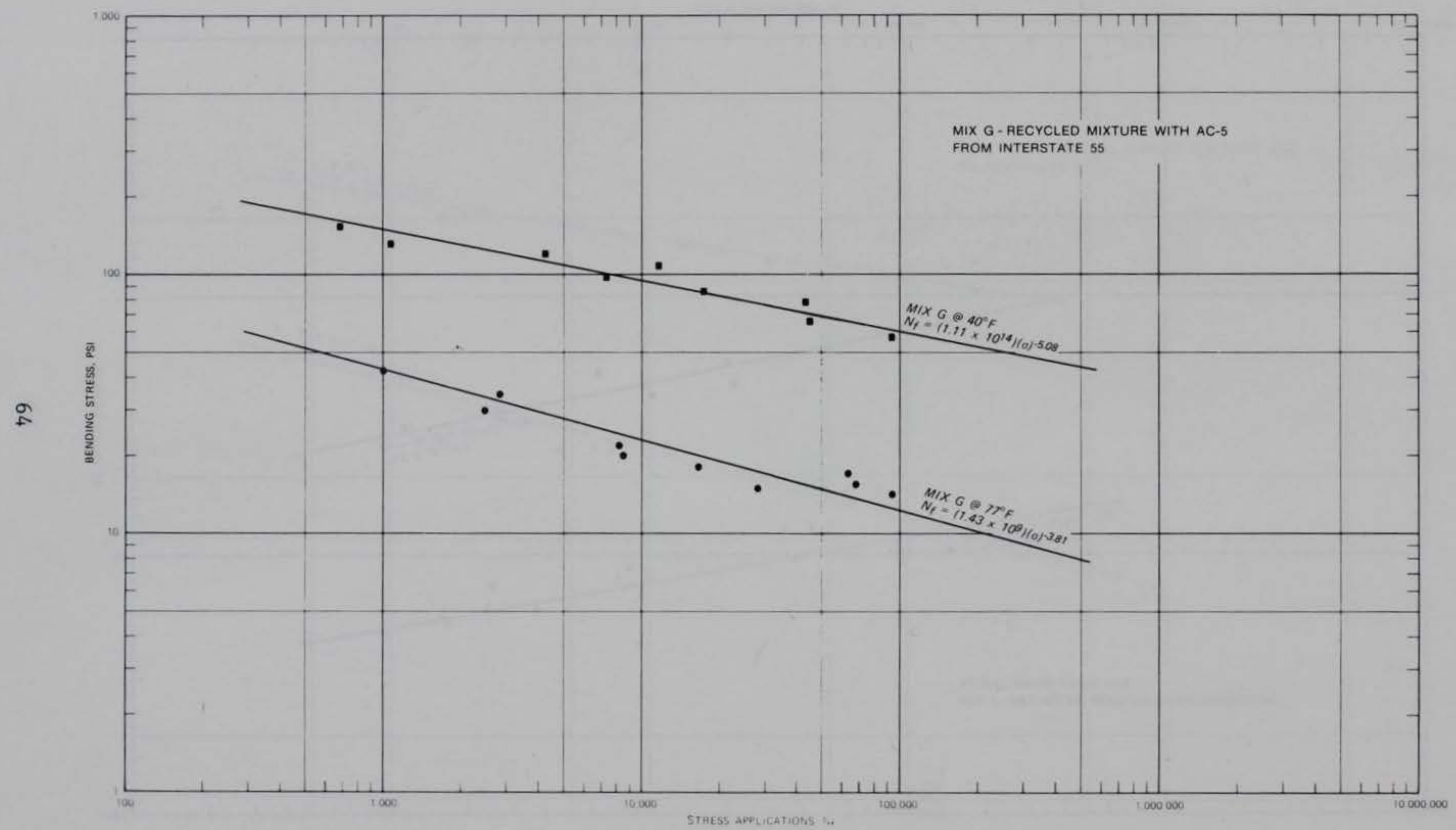

FIG. 10.--Fatigue Results for Mix $G$ as a Function of Bending Stress 


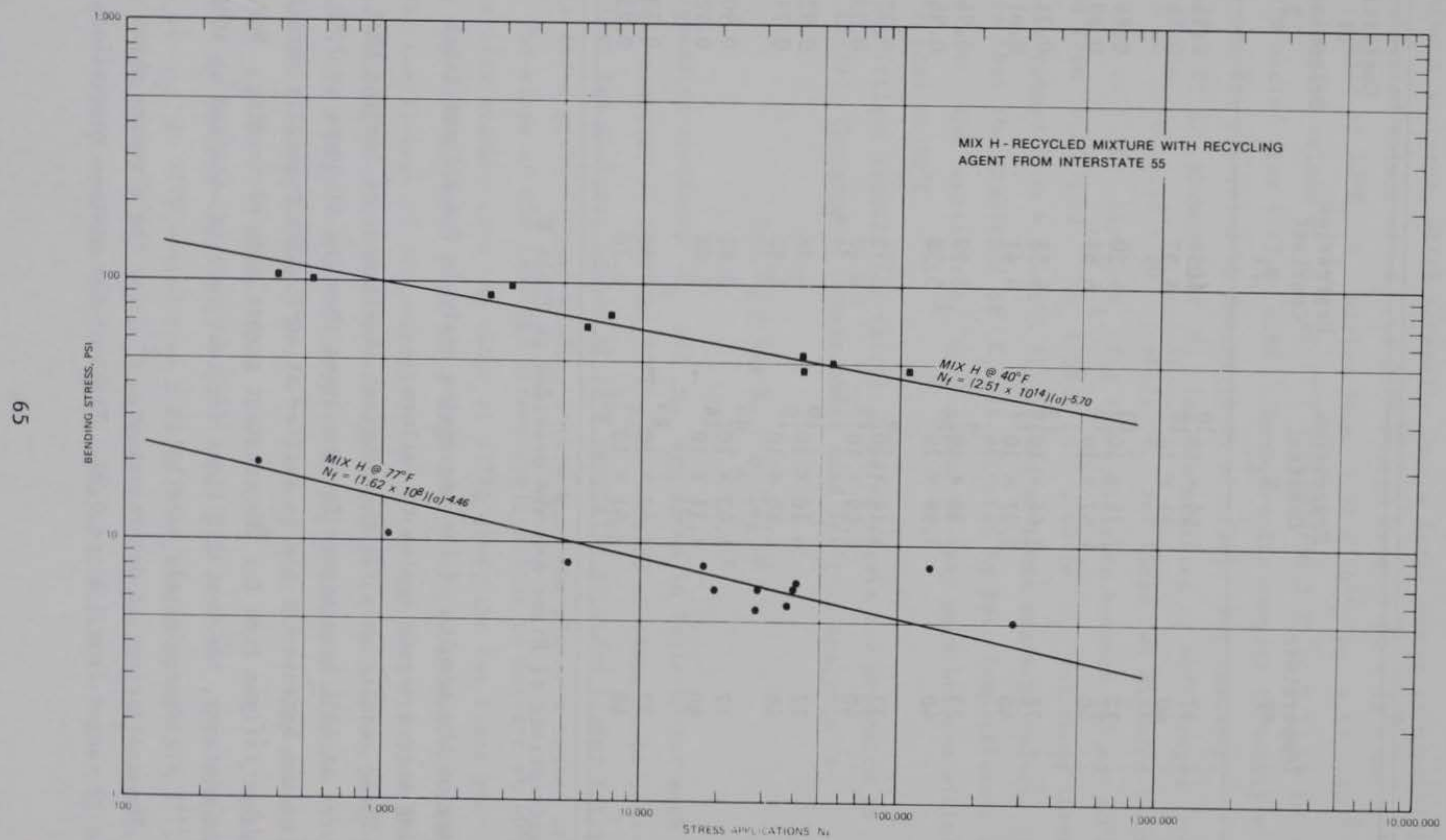

FIG. 11.--Fatigue Results for Mix $\mathrm{H}$ as a Function of Bending Stress 
TABLE 19.--Fatigue Results for Extreme Fiber Bending Stress

\begin{tabular}{|c|c|c|c|c|}
\hline $\begin{array}{l}\text { Mix* } \\
\text { Type }\end{array}$ & $\begin{array}{l}\text { Temperature } \\
{ }^{\circ} \mathrm{F}\end{array}$ & $\begin{array}{c}\text { Regression } \\
\text { Constant } \\
\mathrm{K}_{1}\end{array}$ & $\begin{array}{c}\text { Regression } \\
\text { Constant } \\
n_{1}\end{array}$ & $\begin{array}{c}\text { Coefficient } \\
\text { of } \\
\text { Determination } \\
r^{2}\end{array}$ \\
\hline A & $\begin{array}{l}77 \\
40\end{array}$ & $\begin{array}{l}6.50 \times 10^{10} \\
1.31 \times 10^{18}\end{array}$ & $\begin{array}{l}4.54 \\
6.37\end{array}$ & $\begin{array}{l}0.95 \\
0.86\end{array}$ \\
\hline B & $\begin{array}{l}77 \\
40\end{array}$ & $\begin{array}{l}2.75 \times 10^{13} \\
4.57 \times 10^{18}\end{array}$ & $\begin{array}{l}6.20 \\
6.88\end{array}$ & $\begin{array}{l}0.86 \\
0.80\end{array}$ \\
\hline C & $\begin{array}{l}77 \\
40\end{array}$ & $\begin{array}{l}6.64 \times 10^{12} \\
3.37 \times 10^{12}\end{array}$ & $\begin{array}{l}9.53 \\
4.41\end{array}$ & $\begin{array}{l}0.71 \\
0.61\end{array}$ \\
\hline D & $\begin{array}{l}77 \\
40\end{array}$ & $\begin{array}{l}2.86 \times 10^{9} \\
3.98 \times 10^{15}\end{array}$ & $\begin{array}{l}3.99 \\
5.58\end{array}$ & $\begin{array}{l}0.94 \\
0.98\end{array}$ \\
\hline E & $\begin{array}{l}77 \\
40\end{array}$ & $\begin{array}{l}1.14 \times 10^{9} \\
1.09 \times 10^{18}\end{array}$ & $\begin{array}{l}3.75 \\
6.47\end{array}$ & $\begin{array}{l}0.75 \\
0.93\end{array}$ \\
\hline F & $\begin{array}{l}77 \\
40\end{array}$ & $\begin{array}{l}4.16 \times 10^{10} \\
1.86 \times 10^{16}\end{array}$ & $\begin{array}{l}4.96 \\
5.82\end{array}$ & $\begin{array}{l}0.92 \\
0.79\end{array}$ \\
\hline G & $\begin{array}{l}77 \\
40\end{array}$ & $\begin{array}{l}1.43 \times 10^{9} \\
1.11 \times 10^{14}\end{array}$ & $\begin{array}{l}3.81 \\
5.08\end{array}$ & $\begin{array}{l}0.90 \\
0.92\end{array}$ \\
\hline H & $\begin{array}{l}77 \\
40\end{array}$ & $\begin{array}{l}1.62 \times 10^{8} \\
2.51 \times 10^{14}\end{array}$ & $\begin{array}{l}4.46 \\
5.70\end{array}$ & $\begin{array}{l}0.73 \\
0.93\end{array}$ \\
\hline
\end{tabular}

* Descriptions of Mixes A-H are provided in Table 8.

summary of the results of the regression analysis for extreme fiber bending stress versus cycles to failure.

These results show for the constant stress mode of loading that the mixtures at $40^{\circ} \mathrm{F}$ have higher fatigue lives than the mixtures at $77^{\circ} \mathrm{F}$. This occurs because the mix is stiffer at $40^{\circ} \mathrm{F}$ which typically results in higher fatigue life for the constant stress mode of loading. For most of the mixtures, the best-fit lines for test results obtained at $40^{\circ} \mathrm{F}$ and $77^{\circ} \mathrm{F}$ are approximately parallel.

The coefficient of determination, $r^{2}$, for the mixtures shown in Table 19 ranged from 0.61 to 0.98 . Eight of the sixteen regressions had 
an $r^{2}$ greater than 0.90 . This is a high degree of correlation for bituminous mixtures, which generally show a large amount of variability. The extimated values of $\mathrm{K}_{1}$ at $77^{\circ} \mathrm{F}$ varied from $1.62 \times 10^{8}$ to $2.75 \times$ $10^{13}$, while at $40^{\circ} \mathrm{F}, K_{1}$ varied from $3.37 \times 10^{12}$ to $4.57 \times 10^{18}$. The estimated values of $\mathrm{n}_{1}$ at $77^{\circ} \mathrm{F}$ varied from 3.75 to 9.53 while $\mathrm{n}_{1}$ at $40^{\circ} \mathrm{F}$ varied from 4.41 to 4.88 . These results compare favorably with those results presented by Monismith et al. (56). For instance, Monismith et al. showed that $K_{1}$ for two mixtures at $40^{\circ} \mathrm{F}$ ranged from $1.55 \times 10^{16}$ to $1.16 \times 10^{18}$, while $n_{1}$ for these two mixtures ranged from 4.97 to 5.71. Also, $K_{1}$ for three mixtures between $68^{\circ}$ and $83^{\circ} \mathrm{F}$ ranged from $4.03 \times 10^{13}$ to $1.55 \times 10^{16}$, while $\mathrm{n}_{1}$ for these three mixtures ranged from 4.97 to 5.71 . Based on these measured values, it appears that the magnitude of $K_{1}$ is affected by test temperatures, but $\mathrm{n}_{1}$ is not. The constant $\mathrm{n}_{1}$ does appear to vary more between mixtures at $77^{\circ} \mathrm{F}$ than at $40^{\circ} \mathrm{F}$.

The fatigue results for initial bending strain are presented in Figs. 12-19. The general linear model used for this analysis is

$$
\log \mathrm{N}_{\mathrm{f}}=\log \mathrm{K}_{2}+\mathrm{n}_{2} \log \frac{1}{\varepsilon}
$$

The regression constants $\mathrm{K}_{2}$ and $\mathrm{n}_{2}$ are shown in Table 20 for each of the eight mixtures at $40^{\circ} \mathrm{F}$ and $77^{\circ} \mathrm{F}$. The results of these tests indicated that the mixtures tested at $77^{\circ} \mathrm{F}$ generally provided higher fatigue results for a given initial bending strain than the mixtures tested at $40^{\circ} \mathrm{F}$. The slope of the line for stress applications to failure at $40^{\circ} \mathrm{F}$ is generally steeper than the slope at $77^{\circ} \mathrm{F}$; thus, the two lines generally approach a common point at a high number of stress applications.

The coefficient of determination, $r^{2}$, for the best-fit lines for initial bending strain versus stress applications to failure varies from 0.72 to 0.98 , a high degree of correlation for bituminous mixtures.

Eight of the sixteen mixtures had $r^{2}$ greater than 0.90 . The estimated values of $\mathrm{K}_{2}$ at $77^{\circ} \mathrm{F}$ varied from $1.61 \times 10^{-8}$ to $8.2 \times 10^{-3}$, while at $40^{\circ} \mathrm{F}, \mathrm{K}_{2}$ varied from $1.11 \times 10^{-11}$ to $4.26 \times 10^{-5}$. The estimated values of $\mathrm{n}_{2}$ at $77^{\circ} \mathrm{F}$ varied from 2.00 to 3.78 , while at $40^{\circ} \mathrm{F}, \mathrm{n}_{2}$ varied from 2.50 to 4.21. Again, the results obtained for $K_{2}$ and $n_{2}$ compare favorably with the results presented by Monismith et al. (56). 


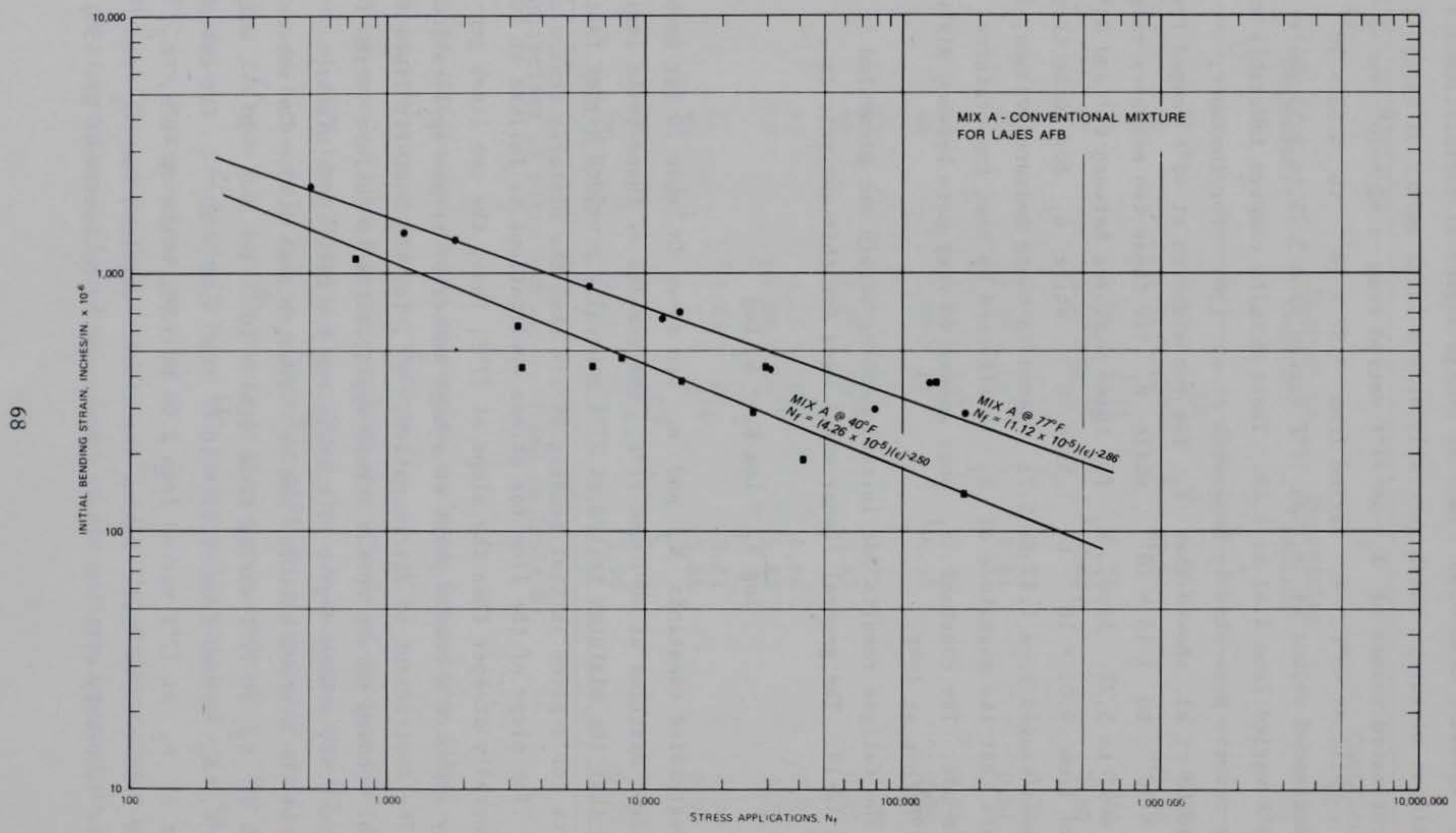

FIG. 12.--Fatigue Results for Mix A as a Function of Initial Bending Strain 


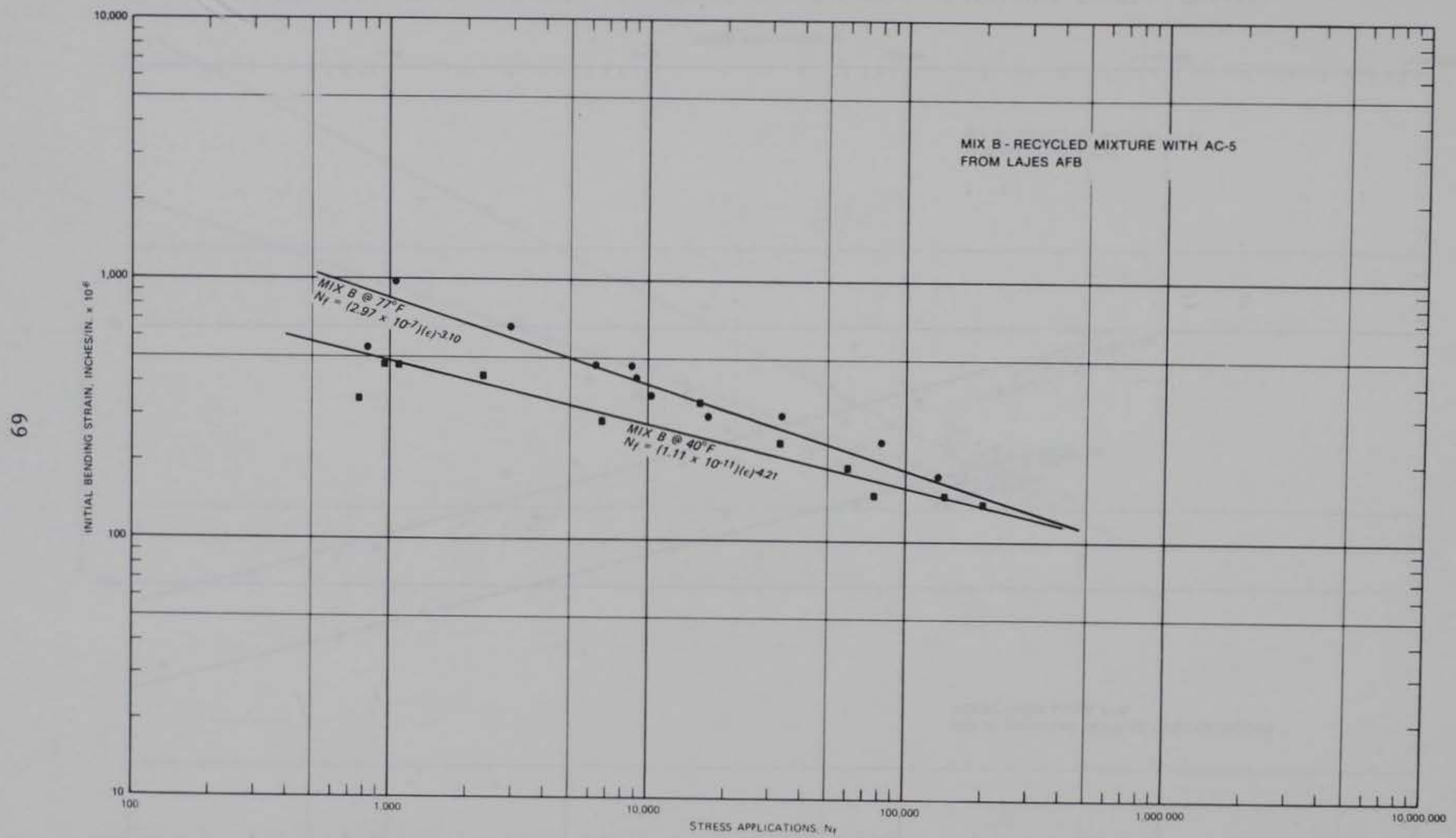

FIG. 13.--Fatigue Results of Mix B as a Function of Initial Bending Strain 


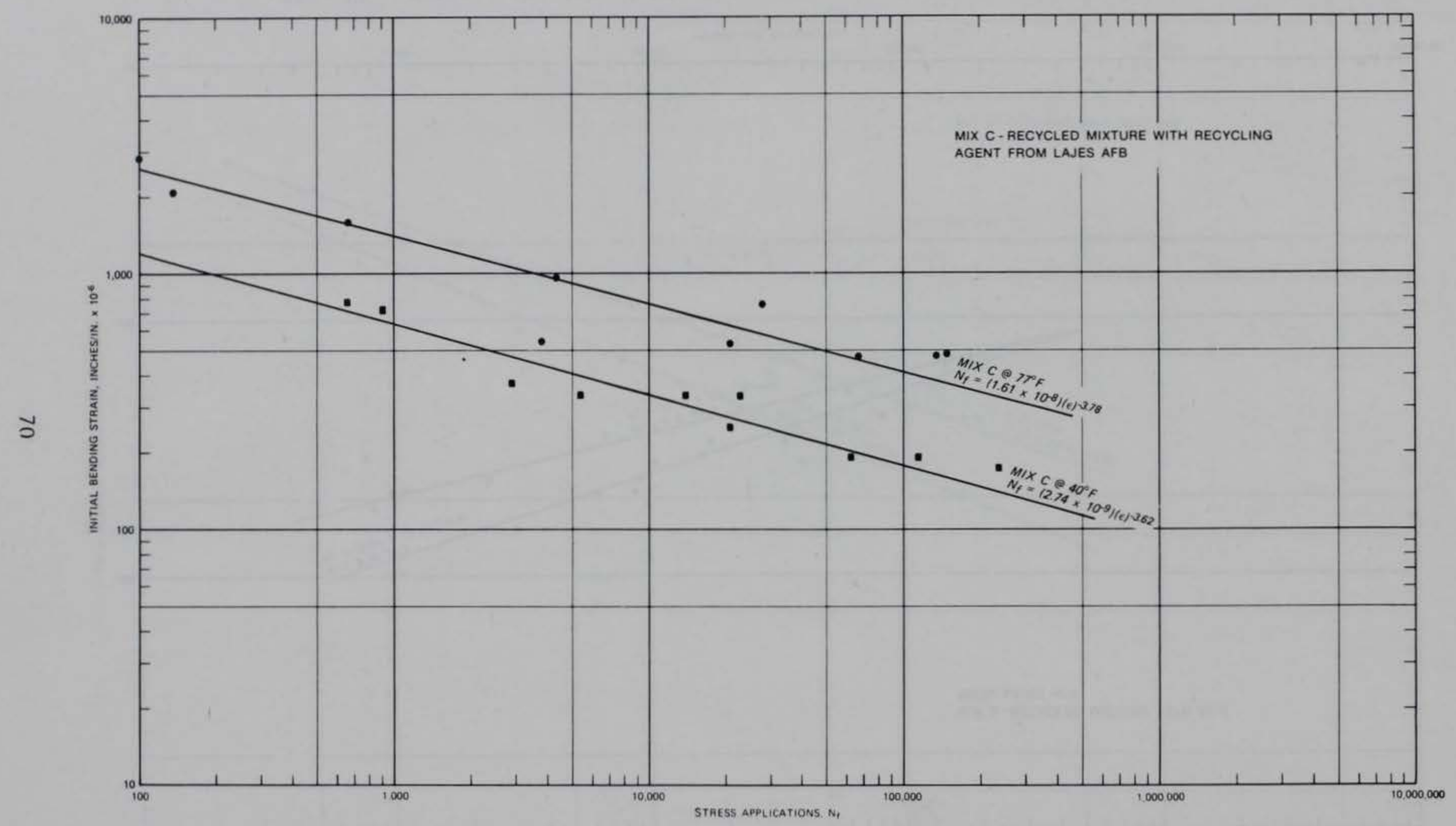

FIG. 14.--Fatigue Results for Mix C as a Function of Initial Bending Strain 


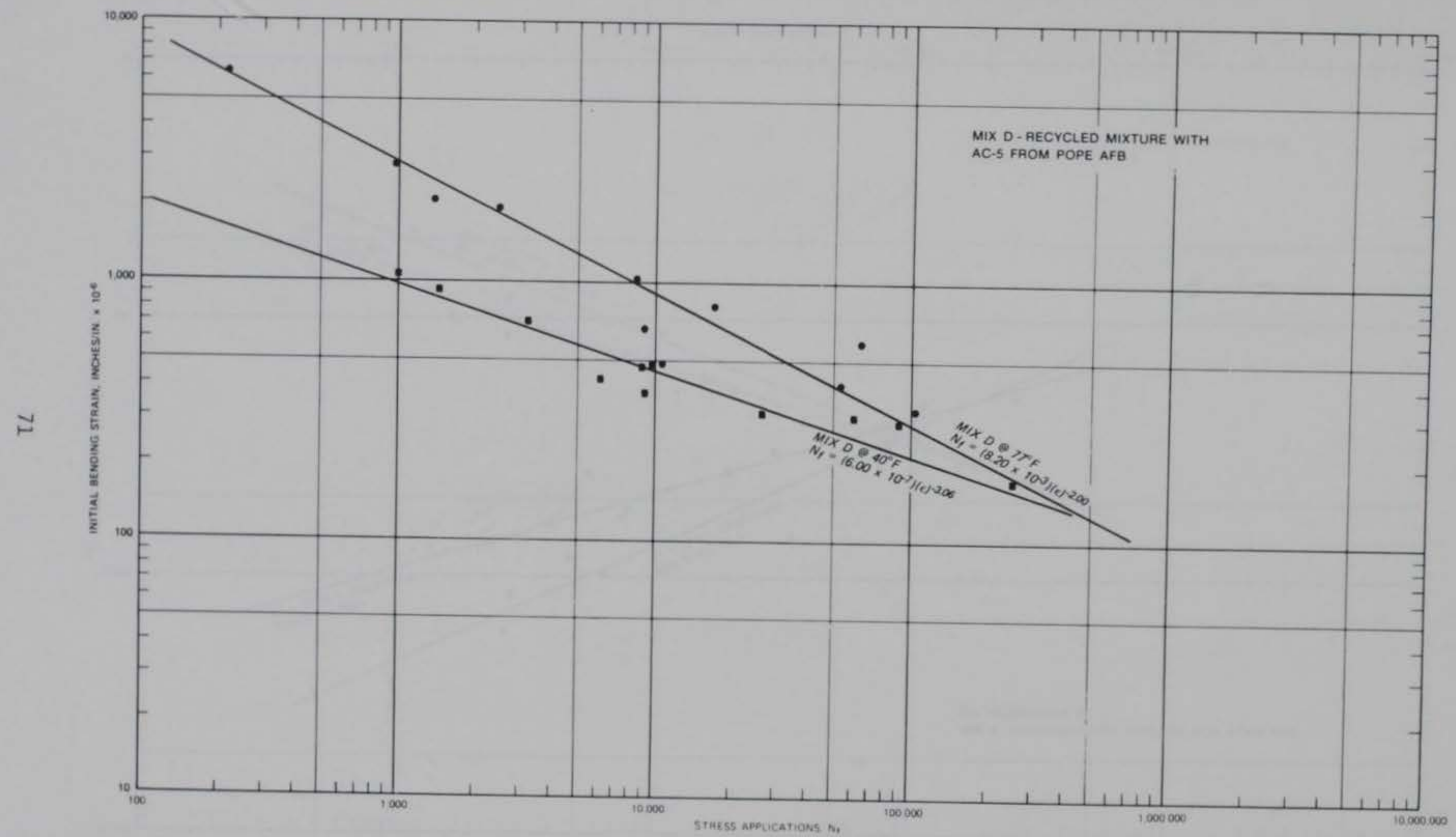

FIG. 15.--Fatigue Results of Mix D as a Function of Initial Bending Strain 


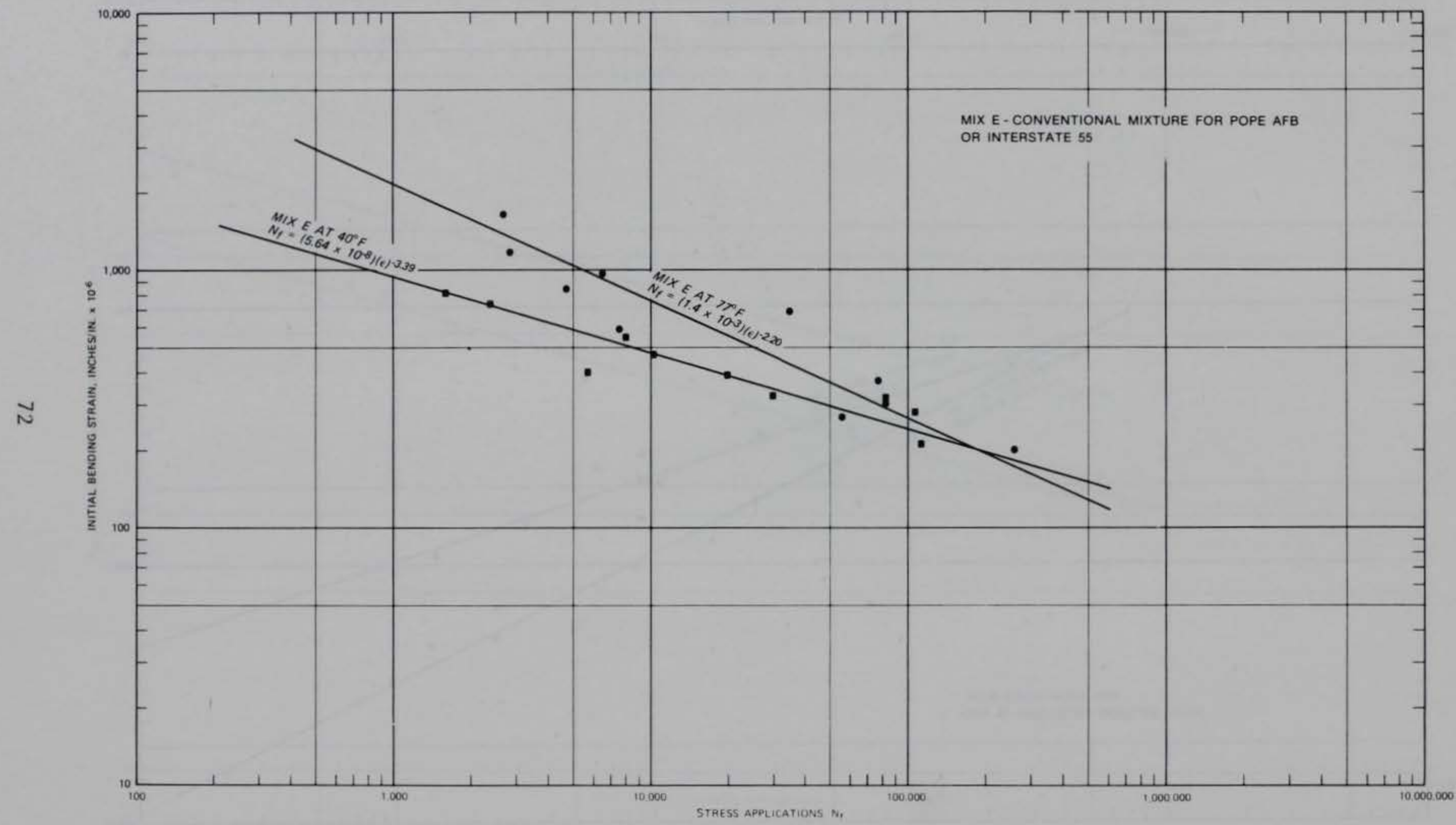

FIG. 16.--Fatigue Results of Mix E as a Function of Initial Bending Strain 


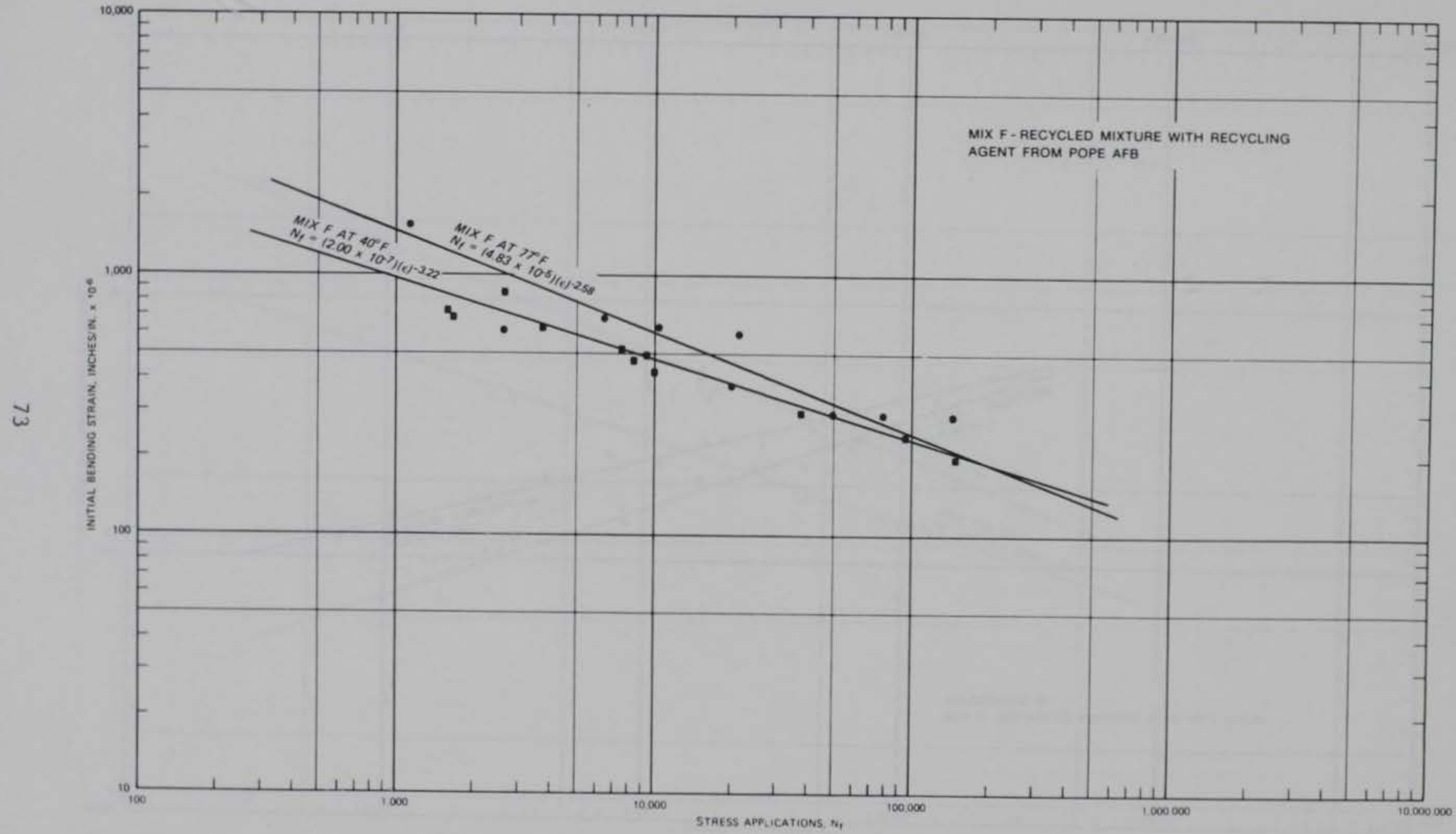

FIG. 17.--Fatigue Results of Mix F as a Function of Initial Bending Strain 


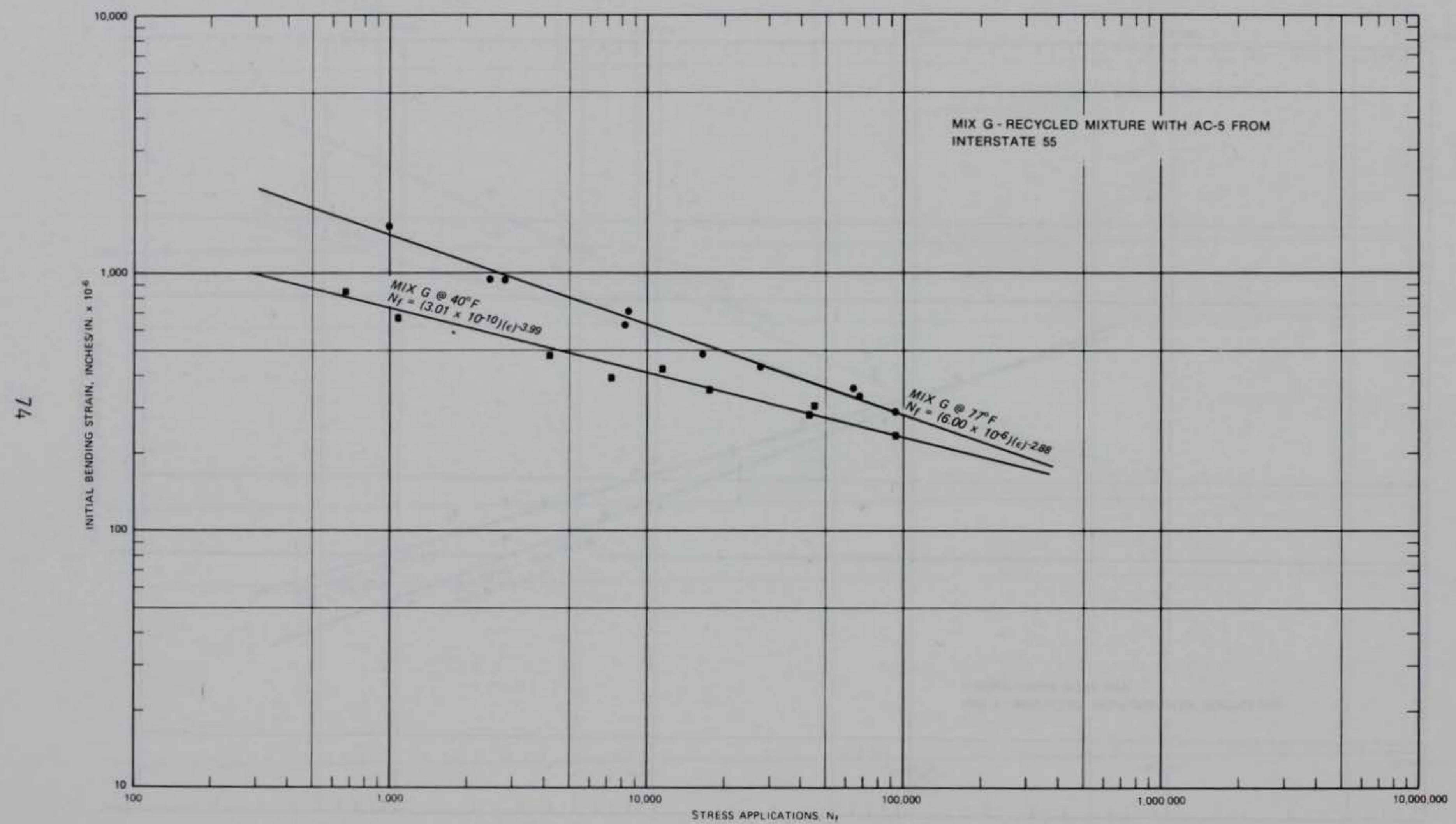

FIG. 18.--Fatigue Results of Mix G as a Function of Initial Bending Strain 


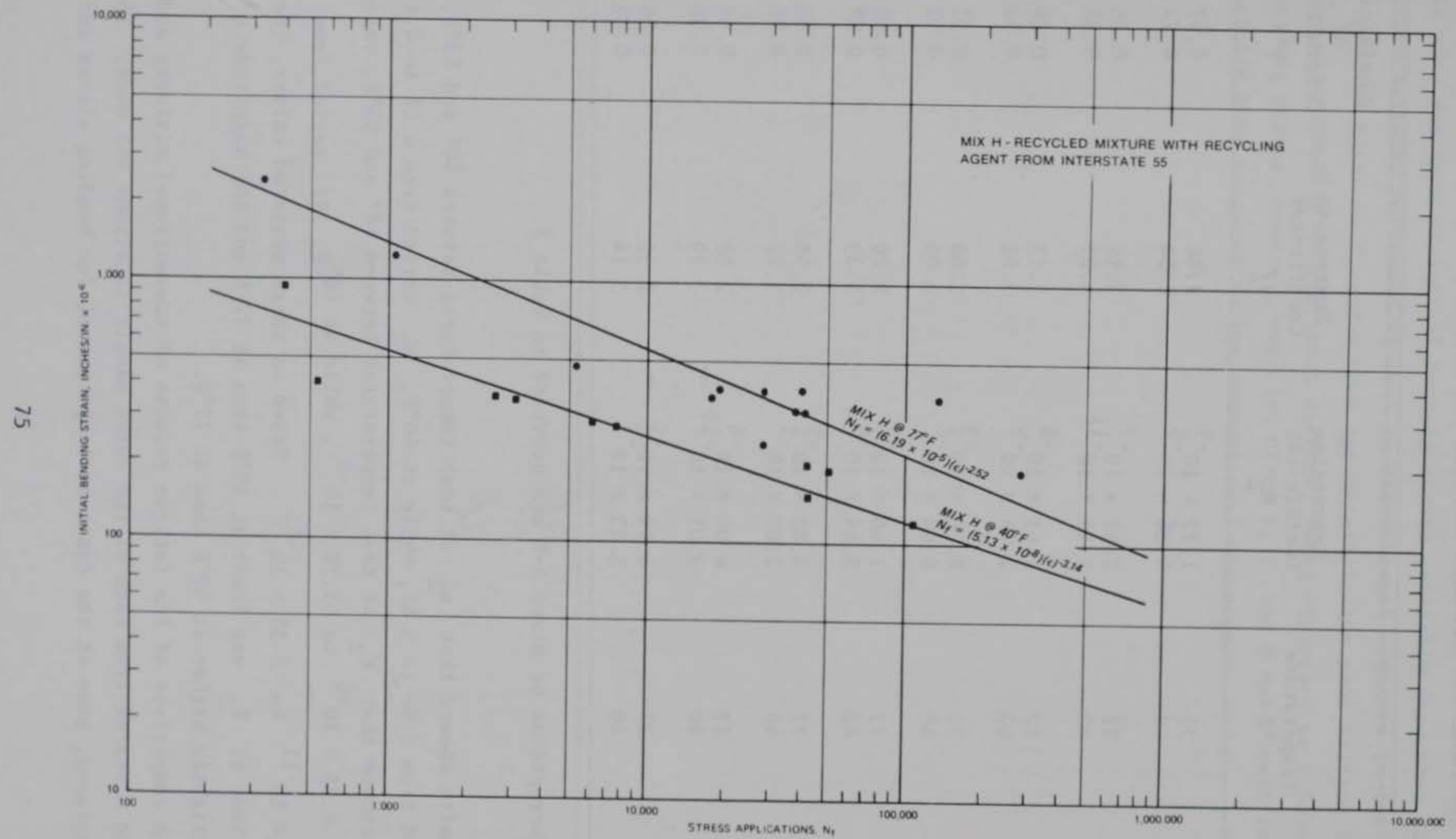

FIG. 19.--Fatigue Results of Mix $\mathrm{H}$ as a Function of Initial Bending Strain 
TABLE 20.--Fatigue Results for Strain in Extreme Fiber

\begin{tabular}{|c|c|c|c|c|}
\hline $\begin{array}{l}\text { Mix* } \\
\text { Type }\end{array}$ & $\begin{array}{c}\text { Temperature } \\
{ }^{\circ} \mathrm{F}\end{array}$ & $\begin{array}{c}\text { Regression } \\
\text { Coefficient } \\
\mathrm{K}_{2}\end{array}$ & $\begin{array}{l}\text { Regression } \\
\text { Coefficient } \\
\mathrm{n}_{2}\end{array}$ & $\begin{array}{c}\text { Coefficient } \\
\text { of } \\
\text { Determination } \\
r^{2}\end{array}$ \\
\hline A & $\begin{array}{l}77 \\
40\end{array}$ & $\begin{array}{l}1.12 \times 10^{-5} \\
4.26 \times 10^{-5}\end{array}$ & $\begin{array}{l}2.86 \\
2.50\end{array}$ & $\begin{array}{l}0.97 \\
0.72\end{array}$ \\
\hline B & $\begin{array}{l}77 \\
40\end{array}$ & $\begin{array}{l}2.97 \times 10^{-7} \\
1.11 \times 10^{-11}\end{array}$ & $\begin{array}{l}3.10 \\
4.21\end{array}$ & $\begin{array}{l}0.86 \\
0.88\end{array}$ \\
\hline C & $\begin{array}{l}77 \\
40\end{array}$ & $\begin{array}{l}1.61 \times 10^{-8} \\
2.74 \times 10^{-9}\end{array}$ & $\begin{array}{l}3.78 \\
3.62\end{array}$ & $\begin{array}{l}0.88 \\
0.92\end{array}$ \\
\hline D & $\begin{array}{l}77 \\
40\end{array}$ & $\begin{array}{l}8.20 \times 10^{-3} \\
6.00 \times 10^{-7}\end{array}$ & $\begin{array}{l}2.00 \\
3.06\end{array}$ & $\begin{array}{l}0.91 \\
0.92\end{array}$ \\
\hline $\mathrm{E}$ & $\begin{array}{l}77 \\
40\end{array}$ & $\begin{array}{l}1.40 \times 10^{-3} \\
5.64 \times 10^{-8}\end{array}$ & $\begin{array}{l}2.20 \\
3.39\end{array}$ & $\begin{array}{l}0.88 \\
0.88\end{array}$ \\
\hline $\mathrm{F}$ & $\begin{array}{l}77 \\
40\end{array}$ & $\begin{array}{l}4.83 \times 10^{-5} \\
2.00 \times 10^{-7}\end{array}$ & $\begin{array}{l}2.58 \\
3.22\end{array}$ & $\begin{array}{l}0.83 \\
0.96\end{array}$ \\
\hline G & $\begin{array}{l}77 \\
40\end{array}$ & $\begin{array}{l}6.00 \times 10^{-6} \\
3.01 \times 10^{-10}\end{array}$ & $\begin{array}{l}2.88 \\
3.99\end{array}$ & $\begin{array}{l}0.98 \\
0.98\end{array}$ \\
\hline H & $\begin{array}{l}77 \\
40\end{array}$ & $\begin{array}{l}6.19 \times 10^{-5} \\
5.13 \times 10^{-8}\end{array}$ & $\begin{array}{l}2.52 \\
3.14\end{array}$ & $\begin{array}{l}0.86 \\
0.93\end{array}$ \\
\hline
\end{tabular}

* Descriptions of Mixes A-H are provided in Table 8.

Monismith showed that $\mathrm{n}_{2}$ at test temperatures between $68^{\circ}$ and $83^{\circ} \mathrm{F}$, varied from 2.90 to 3.45 , while at $40^{\circ} \mathrm{F}, \mathrm{n}_{2}$ varied from 4.08 to 4.17 . They showed that $K_{2}$ at test temperatures between $68^{\circ}$ and $83^{\circ} \mathrm{F}$, varied from $6.38 \times 10^{-6}$ to $3.70 \times 10^{-8}$, while at $40^{\circ} \mathrm{F}, \mathrm{K} 2$ varied from $5.20 \times 10^{-11}$ to $8.35 \times 10^{-12}$. Based on these measured values, the magnitude of $\mathrm{K}_{2}$ was lower at $40^{\circ} \mathrm{F}$ than at $77^{\circ} \mathrm{F}$ and the magnitude of $\mathrm{n}_{2}$ was slightly higher at $40^{\circ} \mathrm{F}$ than at $77^{\circ} \mathrm{F}$.

A comparison of the fatigue results of conventional mixtures and recycled mixtures from each of the three sample locations was made. These comparisons, made at the two test temperatures for bending stress and 
initial bending strain, are shown in Figs. 20-31. The fatigue test results as a function of initial bending strain generally show that the recycled mixtures performed as well as conventional mixtures in fatigue. The recycled Mixes D, F, and $G$ have approximately the same fatigue life as the corresponding conventional mixture. When expressed as a function of bending stress, however, recycled Mixes $B, C$, and $H$ have lower fatigue resistance when compared to the conventional mixtures. 


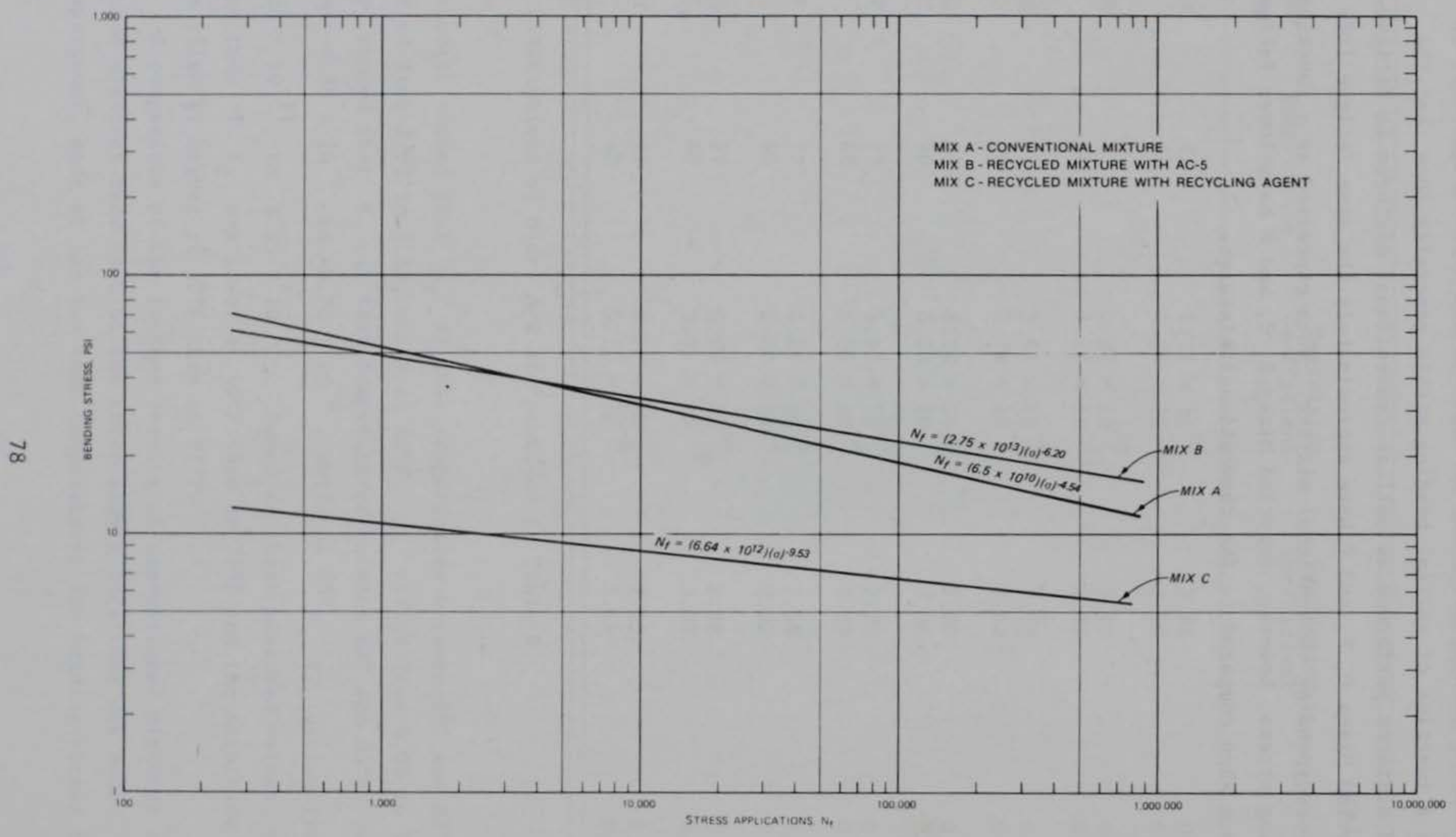

FIG. 20.--Fatigue Results at $77^{\circ} \mathrm{F}$ for Mixes from Lajes Air Force Base as a Function of Bending Stress 


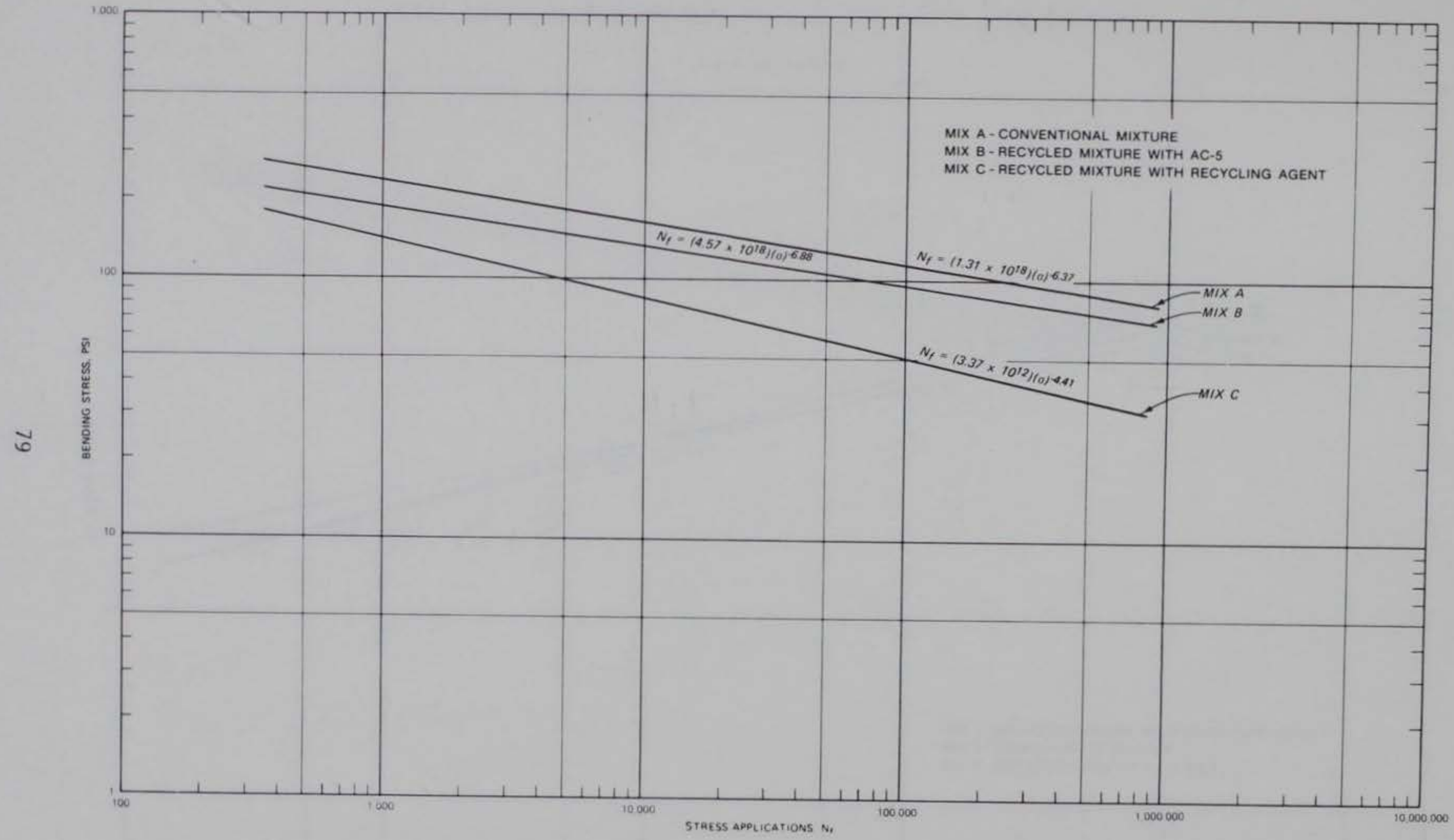

FIG. 21.--Fatigue Results at $40^{\circ} \mathrm{F}$ for Mixes from Lajes Air Force Base as a Function of Bending Stress 


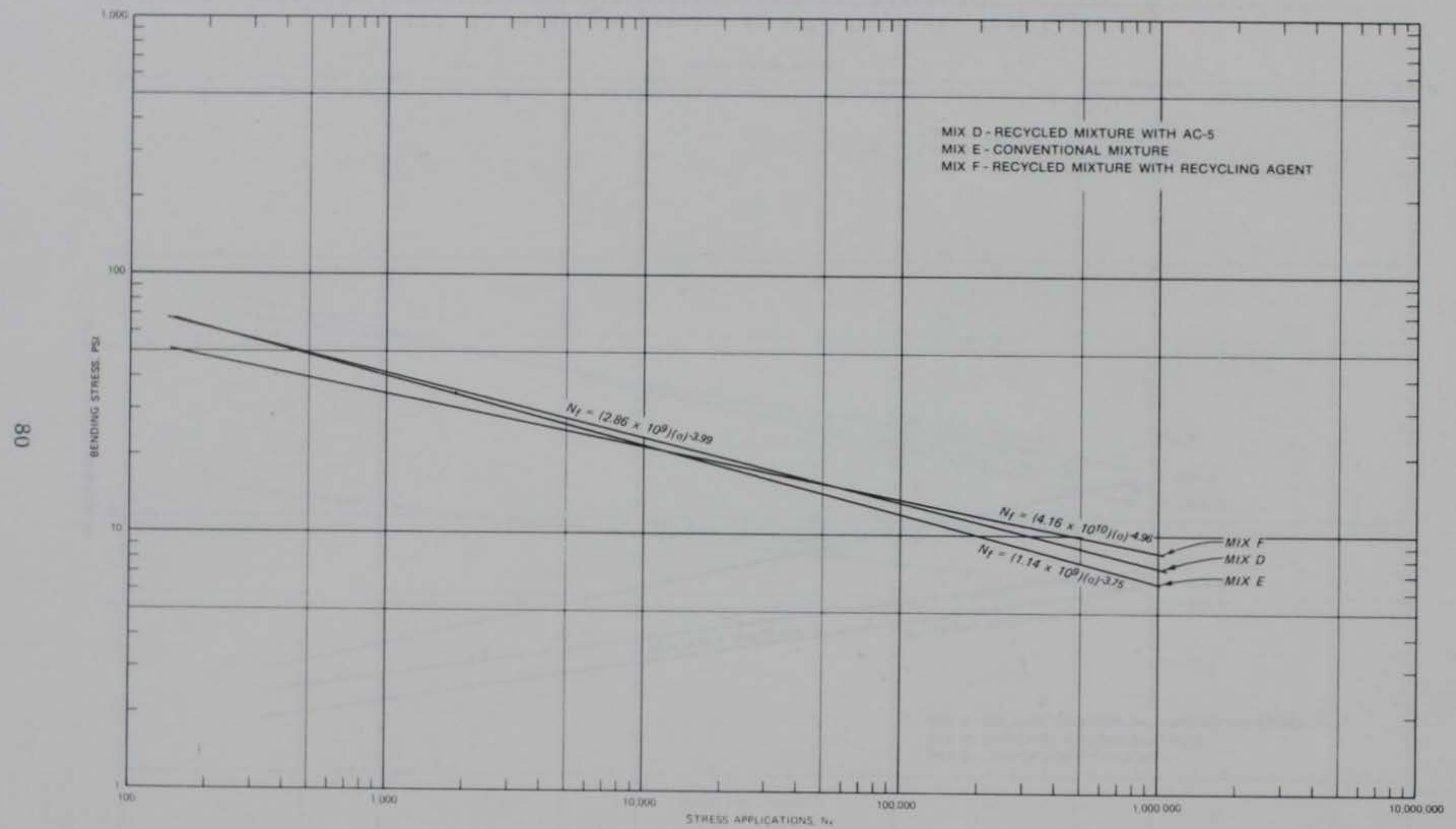

FIG. 22.--Fatigue Results at $77^{\circ} \mathrm{F}$ for Mixes from Pope Air Force Base as a Function of Bending Stress 


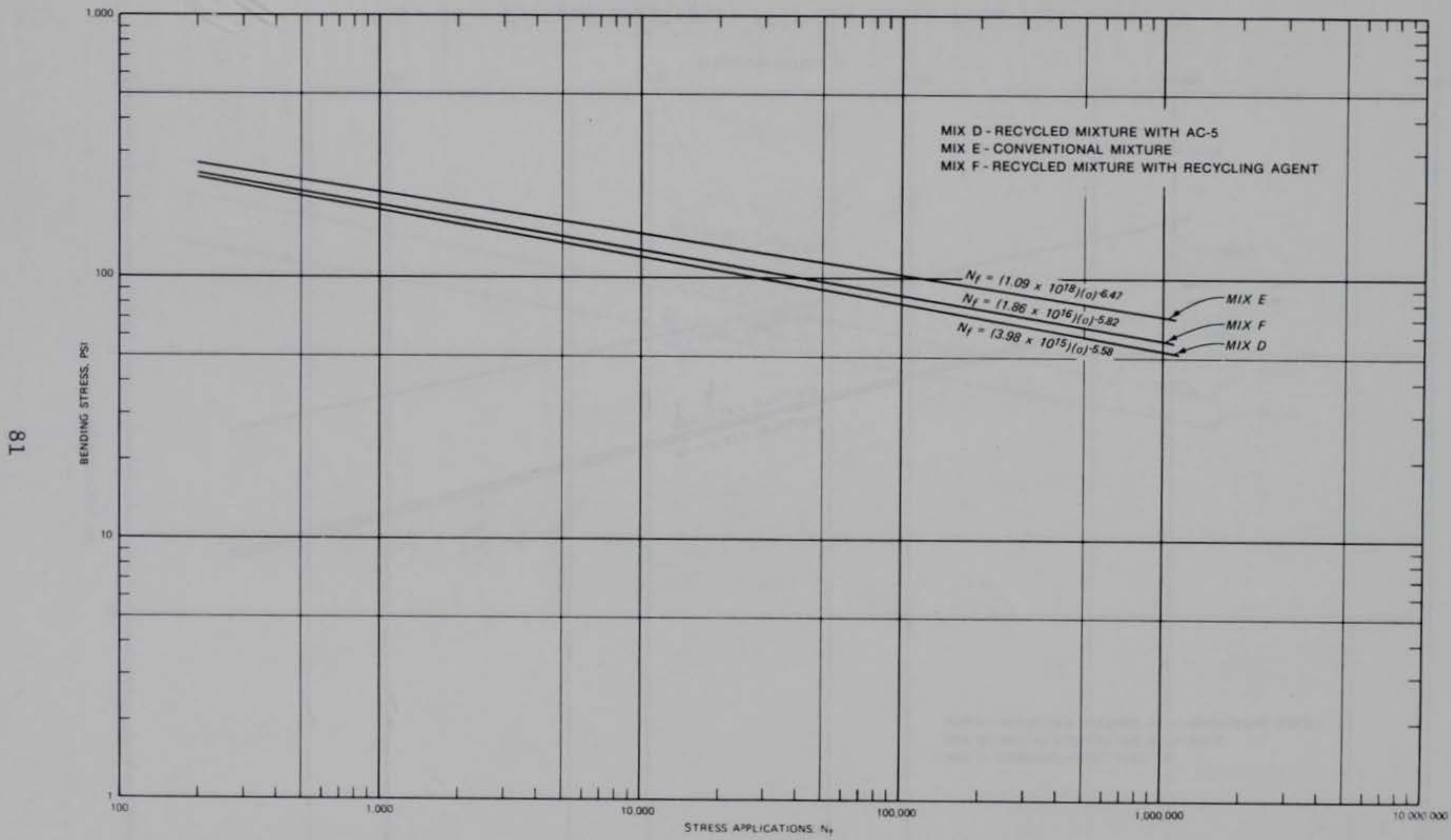

FIG. 23.--Fatigue Results at $40^{\circ} \mathrm{F}$ for Mixes from Pope Air Force Base as a Function of Bending Stress 


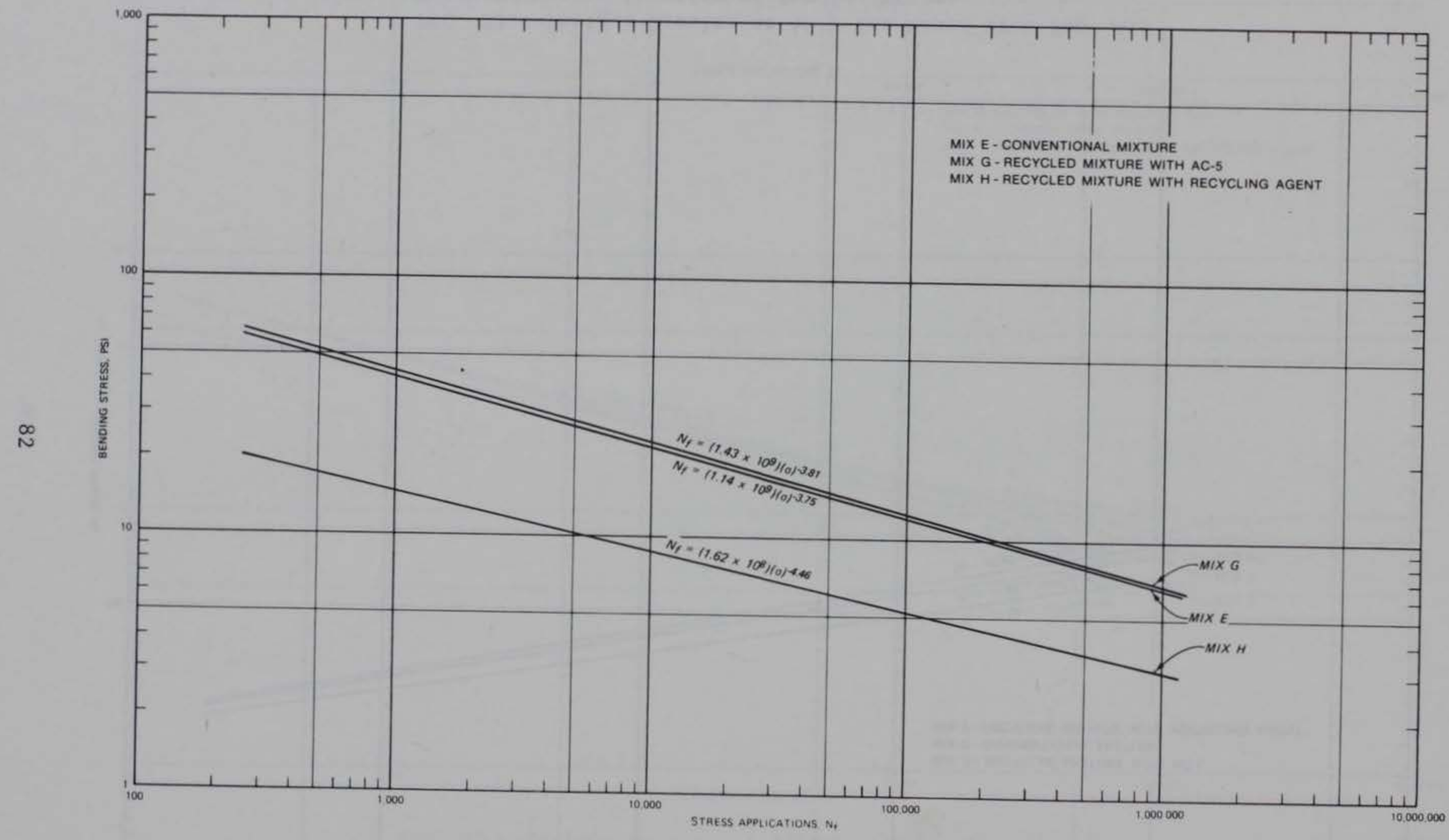

FIG. 24.--Fatigue Results at $77^{\circ} \mathrm{F}$ for Mixes from Interstate 55 as a Function of Bending Stress 


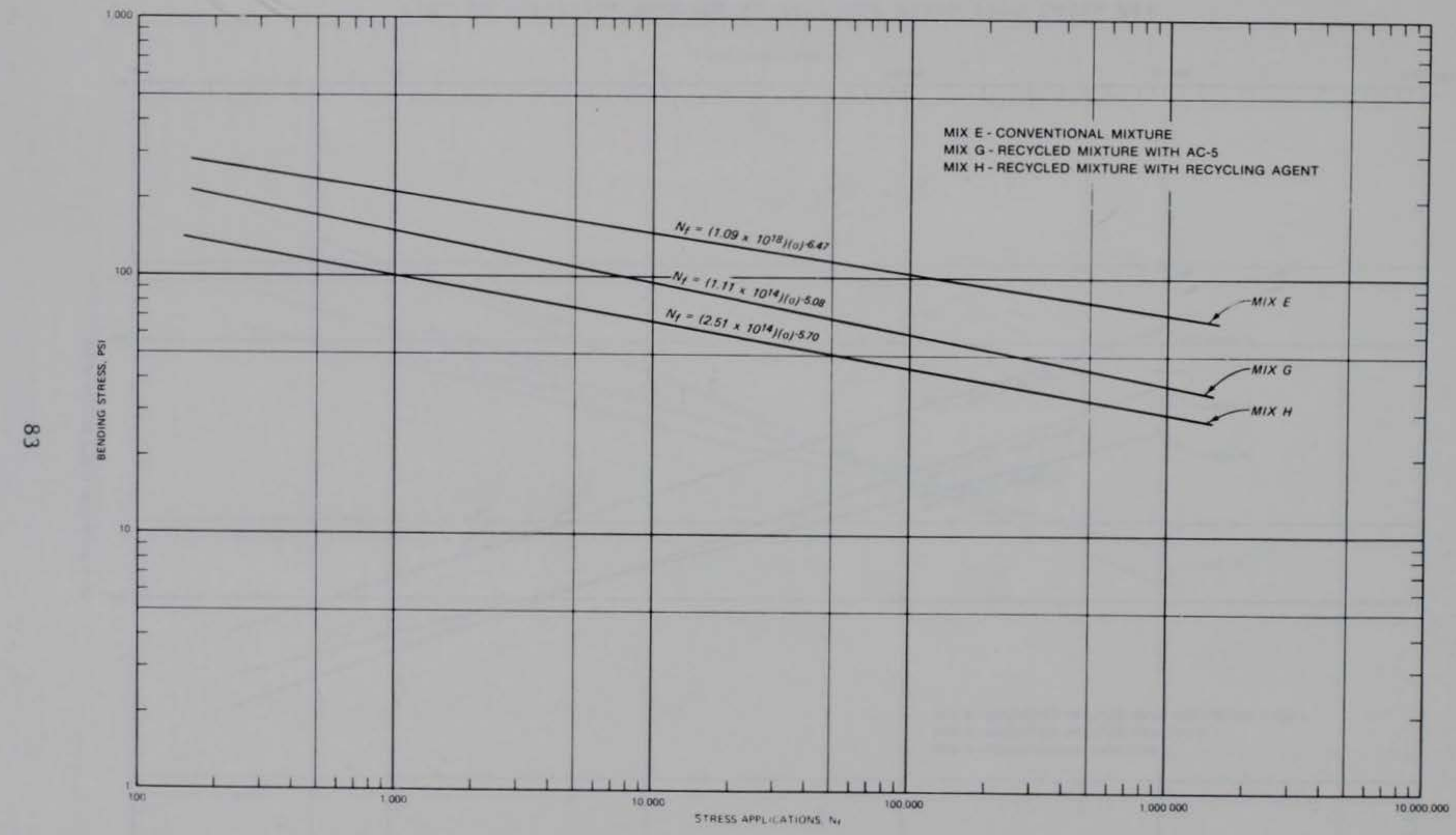

FIG. 25.--Fatigue Results at $40^{\circ} \mathrm{F}$ for Mixes from Interstate 55 as a Function of Bending Stress 


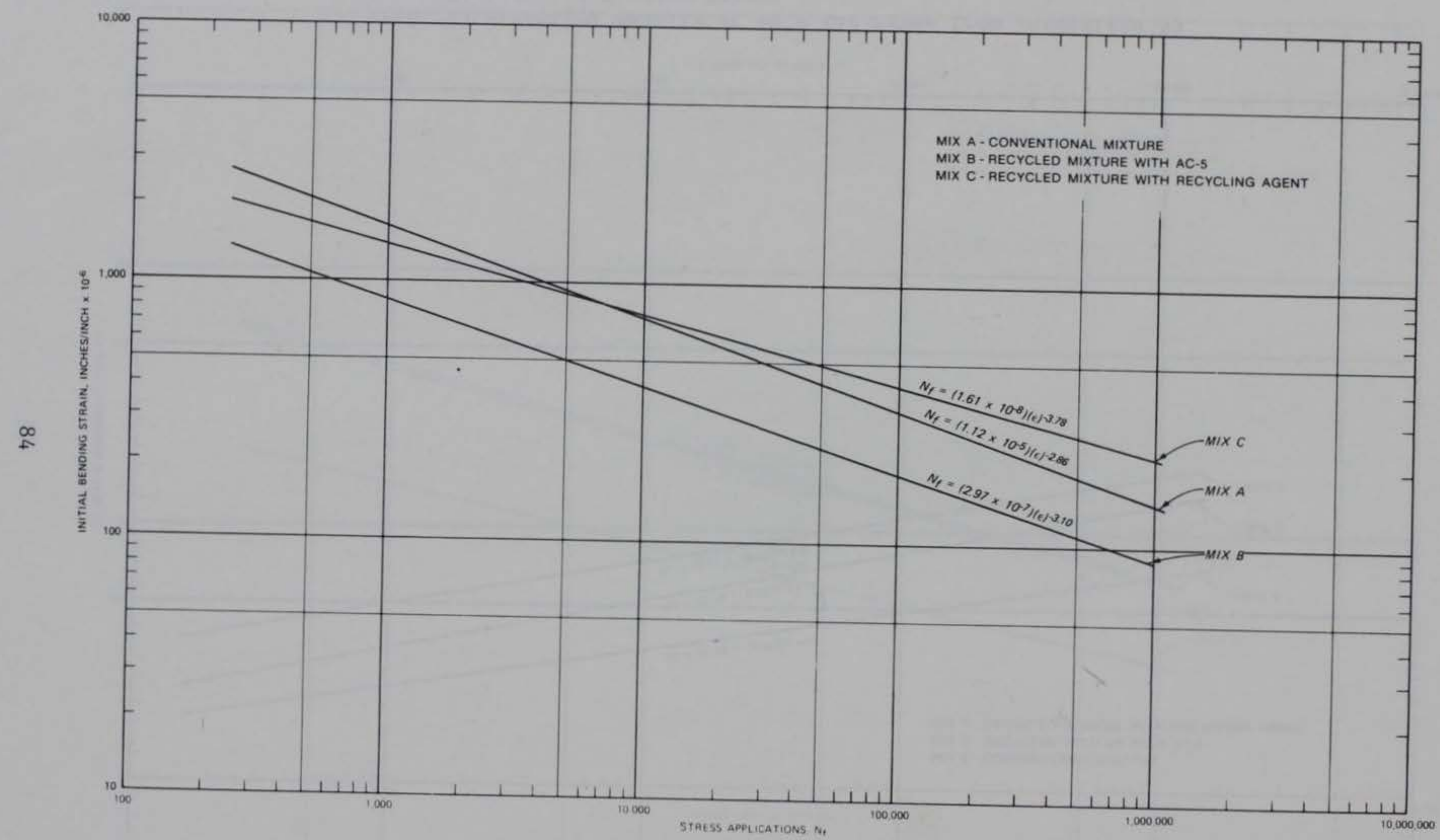

FIG. 26.--Fatigue Results at $77^{\circ} \mathrm{F}$ for Mixes from Lajes Air Force Base as a Function of Initial Bending Strain 


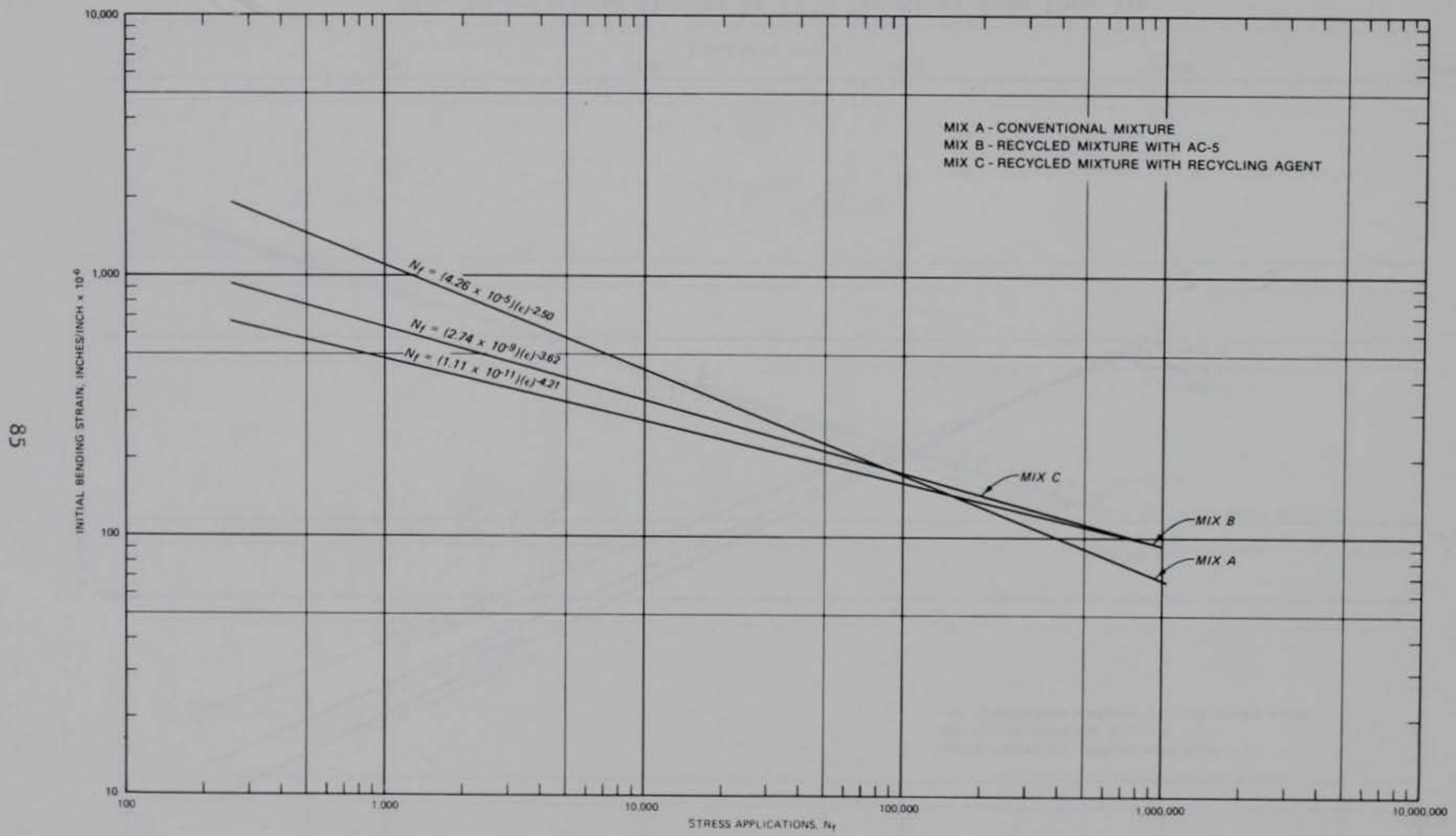

FIG. 27.--Fatigue Results at $40^{\circ} \mathrm{F}$ for Mixes from Lajes Air Force Base as a Function of Initial Bending Strain 


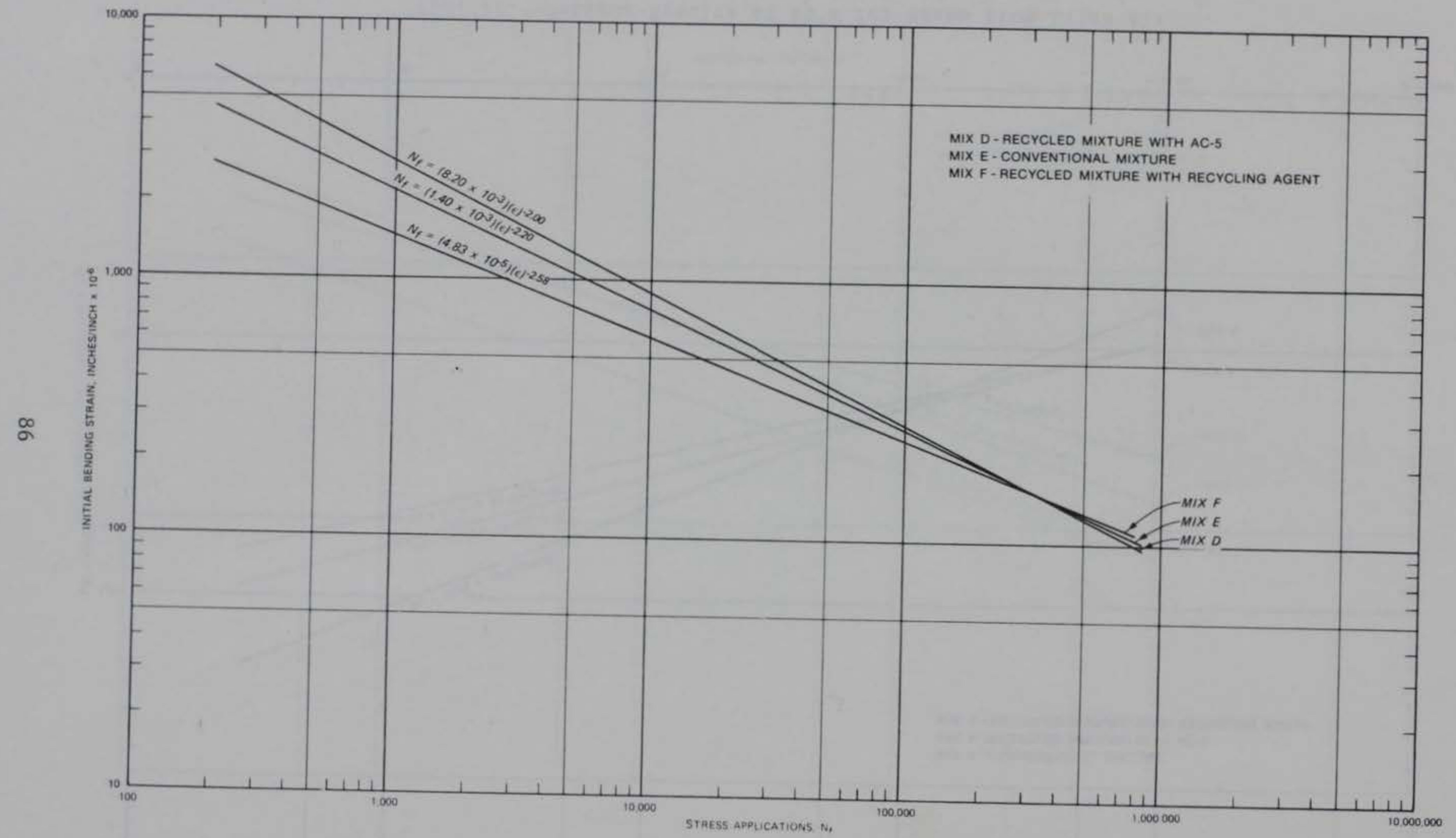

FIG. 28.--Fatigue Results at $77^{\circ} \mathrm{F}$ for Mixes from Pope Air Force Base as a Function of Initial Bending Strain 


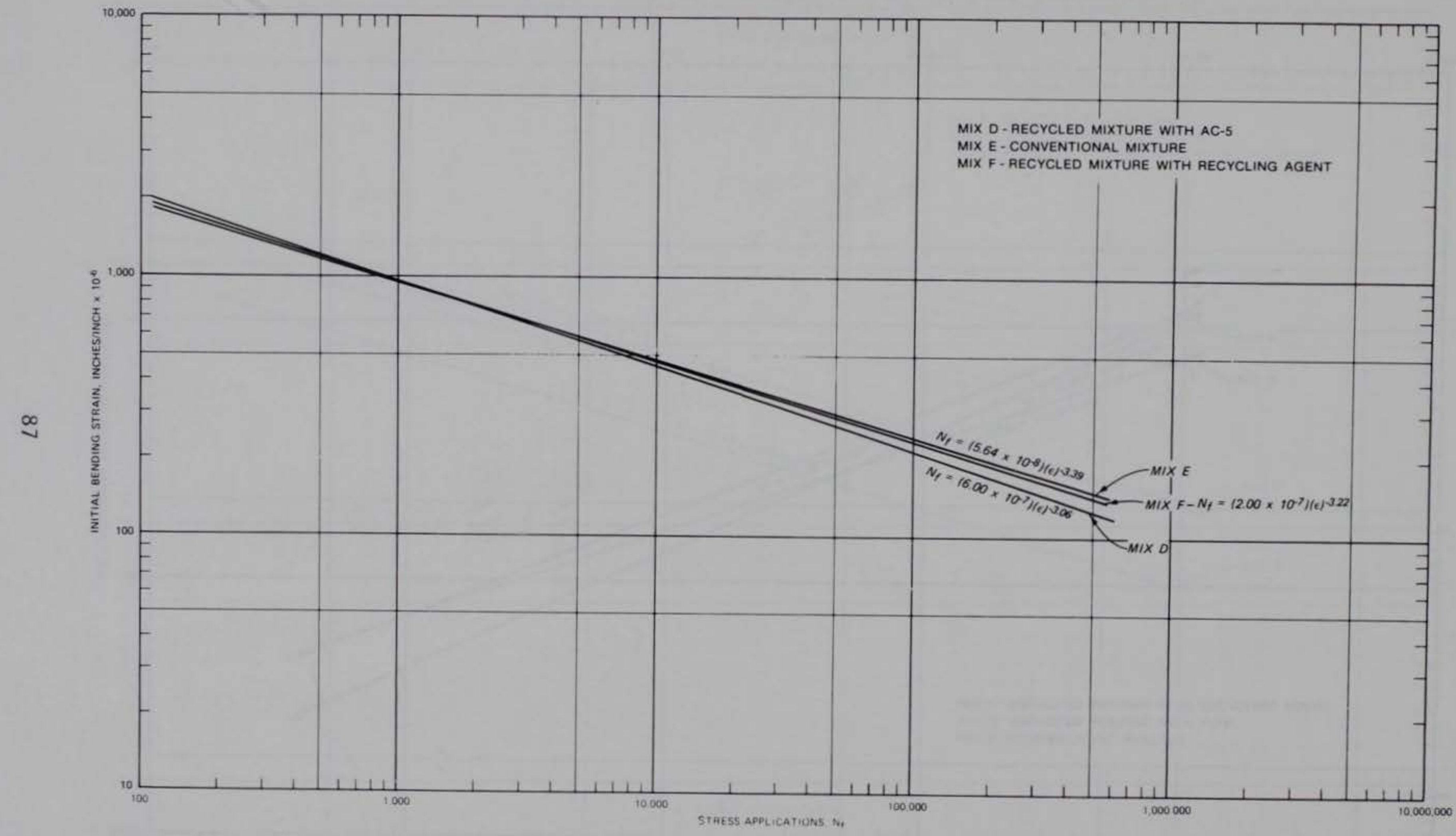

FIG. 29.--Fatigue Results at $40^{\circ} \mathrm{F}$ for Mixes from Pope Air Force Base as a Function of Initial Bending Strain 


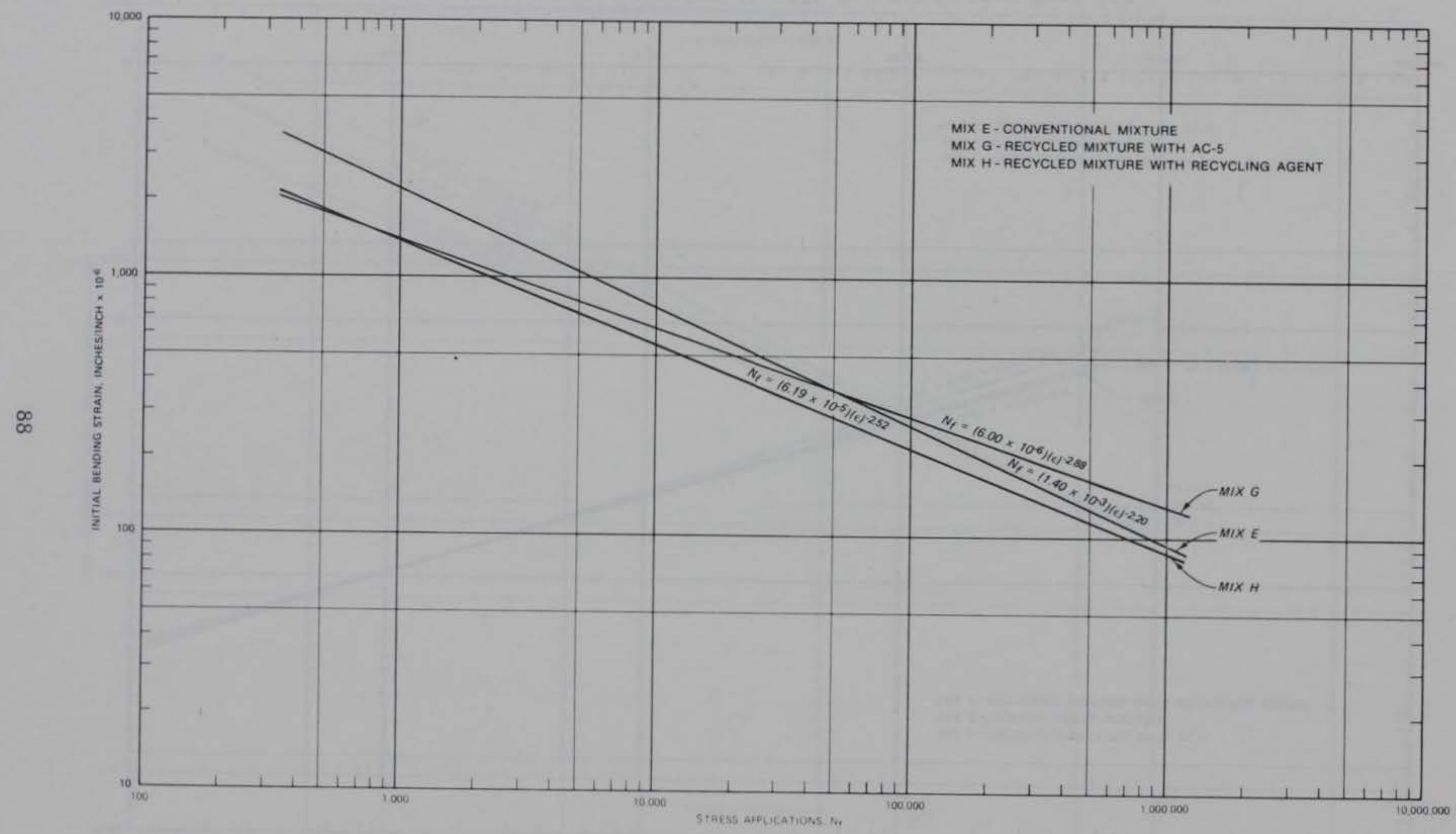

FIG. 30.--Fatigue Results at $77^{\circ} \mathrm{F}$ for Mixes from Interstate 55 as a Function of Initial Bending Strain 


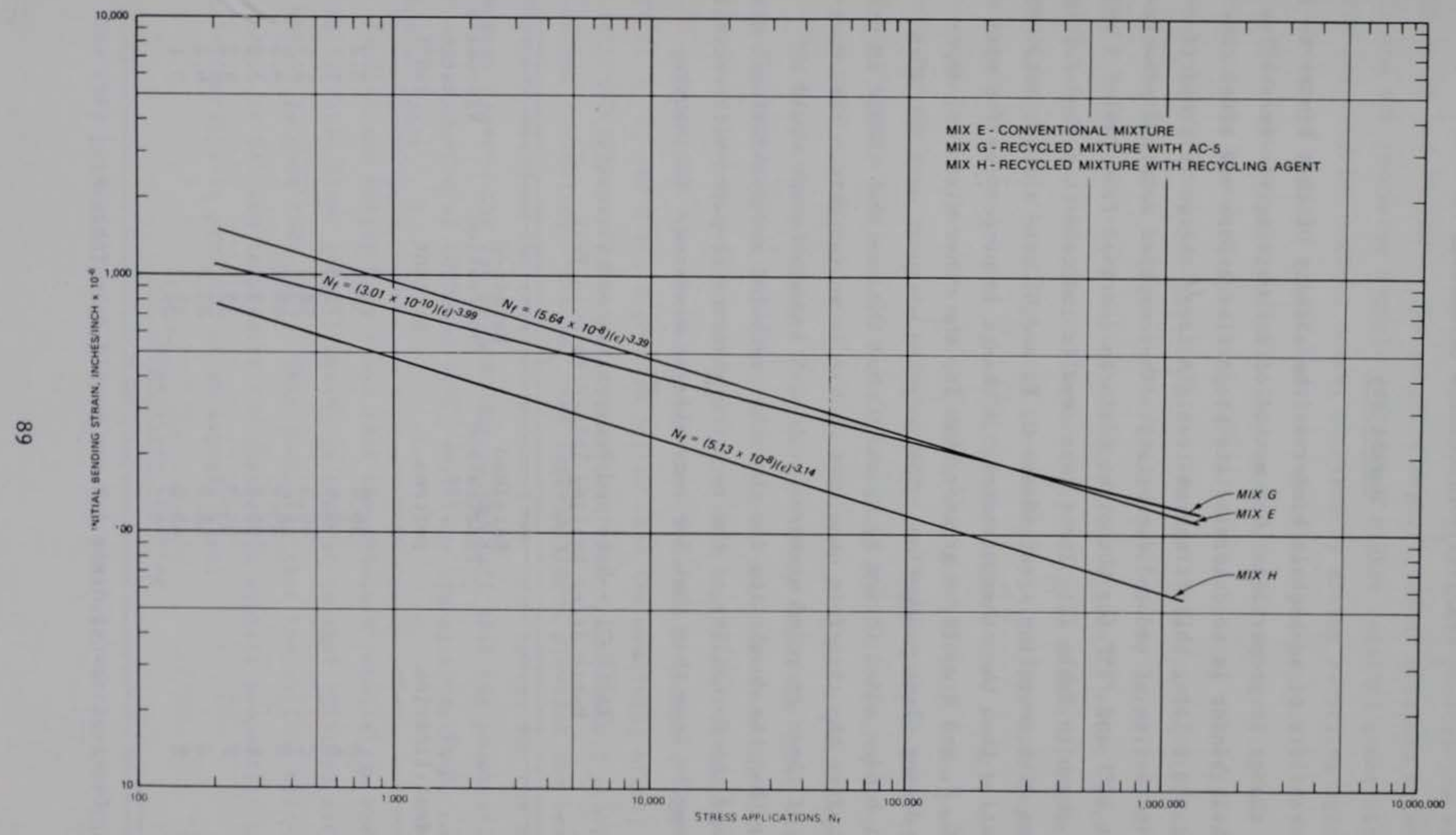

FIG. 31.--Fatigue Results at $40^{\circ} \mathrm{F}$ for Mixes from Interstate 55 as a Function of Initial Bending Strain 


\section{PART VI: DISCUSSION OF RESULTS}

\section{Durability}

Durability of an asphalt binder is the ability of that binder to resist a change in properties. One method of determining the durability of an asphalt binder is to determine its properties before and after conducting the rolling thin-film oven test. A large change in properties is an indication of reduced durability. The computed retained penetration at $40^{\circ} \mathrm{F}$ and $77^{\circ} \mathrm{F}$ for the eight mixtures (derived from Tables 9 and 10) is shown in Table 21. These test results indicate that the recycled mixtures with recycling agent (Mixes $\mathrm{C}, \mathrm{F}$, and $\mathrm{H}$ ) have a lower retained penetration than the other mixtures. A change in properties for mixtures $\mathrm{C}, \mathrm{F}$, and $\mathrm{H}$ would be greater than for the other mixtures, especially during plant production. The recycled mixtures with the AC-5 asphalt binder added (Mixes B, D, and G) had the smallest change in properties after the thin-film oven test. This is an indication that durability of these recycled mixtures with $\mathrm{AC}-5$ asphalt cement would be greater than the durability for the other recycled and conventional mixtures and the durability of the recycled mixtures prepared with recycling agent may be less than that for conventional mixtures. Puzinauskas

TABLE 21.--Retained Penetration and Viscosity Ratio After Rolling Thin-Film Oven Test

\begin{tabular}{cccc}
\hline $\begin{array}{c}\text { Mix* } \\
\text { Identification }\end{array}$ & $\begin{array}{c}\text { Retained } \\
\text { Penetration } \\
77^{\circ} \mathrm{F} \\
\text { percent }\end{array}$ & $\begin{array}{c}\text { Retained } \\
\text { Penetration } \\
40^{\circ} \mathrm{F} \\
\text { percent }\end{array}$ & $\begin{array}{c}\text { Viscosity } \\
\text { Ratio } \\
140^{\circ} \mathrm{F}\end{array}$ \\
\hline A & 56.8 & 57.1 & 3.2 \\
B & 68.6 & 78.3 & 7.1 \\
C & 40.3 & 58.1 & 5.4 \\
D & 64.0 & 68.2 & 4.3 \\
E & 56.8 & 57.1 & 3.2 \\
F & 44.3 & 39.3 & 3.2 \\
G & 58.0 & 83.8 & 6.2 \\
H & 45.0 & 45.1 & 3.1 \\
\hline
\end{tabular}

* Descriptions of Mixes A-H are provided in Table 8. 
showed that most $\mathrm{AC}-20$ asphalt cements have retained penetration values between 55 and 75 (63). The recycled asphalt cement obtained by mixing $\mathrm{AC}-5$ and the recovered asphalt cement had higher retained penetrations, while the recycled asphalt cement obtained by mixing recycling agent and the recovered asphalt cement had lower retained penetrations.

The viscosity ratio (Table 21) was determined by dividing the viscosity of the blended asphalt binders after the rolling thin-film oven test by the viscosity of the original blended binders. The viscosity ratio has also been used as a relative measure of the durability of an asphalt binder. For the tested mixtures, the viscosity ratio ranged from 3.1 to 7.1. Anderson and Dukatz (14) tested a number of asphalt cements and found that in general the viscosity ratio for most asphalt cements is between 2.0 and 3.5. Puzinauskas showed that asphalt cements generally have a viscosity ratio between 1.5 and 3.0 (63). One probable reason for the viscosity ratio being higher in this study is that the asphalt is not a new asphalt cement; whereas, the test results from the two previously mentioned studies were obtained from new asphalt cements.

The conclusions obtained from the viscosity ratio for these mixes generally do not agree with those conclusions obtained from the retained penetration results. The asphalt binders with the lowest viscosity ratio should provide the most durable mixtures. This would indicate that Mixes $\mathrm{A}, \mathrm{E}, \mathrm{F}$, and $\mathrm{H}$ would perform better than the remaining mixes, and the recycled mixtures with the $\mathrm{AC}-5$ asphalt cement added would provide the lowest durability. However, the later mixtures provided the best performance based on the retained penetration. One reason for the disagreement between the two methods may be the fact that the penetration test was conducted at $40^{\circ} \mathrm{F}$ and $77^{\circ} \mathrm{F}$, while the viscosity test was conducted at $140^{\circ} \mathrm{F}$.

Kandhal and Wenger have shown that the retained penetration and viscosity ratio after pugmill mixing is similar to that obtained after the thin-film oven test (46). This indicates that the rolling thin-film oven test can be used to predict the changes in asphalt properties when asphalt concrete is produced at an asphalt plant.

Low Temperature Cracking

Gaw (39) presented a nomograph that has been used to predict the 
temperature at which transverse cracking will occur. The nomograph (Figure 32 ) uses the asphalt penetration at $77^{\circ} \mathrm{F}\left(25^{\circ} \mathrm{C}\right)$ and $40^{\circ} \mathrm{F}\left(5^{\circ} \mathrm{C}\right)$ to predict performance of asphalt concrete mixtures in the field. Using the properties of the asphalt cements shown in Table 11, the temperature at which each of the mixtures will crack was then determined (Table 22). These results indicate that cracking of the recycled mixtures evaluated occurs at a lower temperature in general than the temperature at which the conventional mixtures would crack. Based on the nomograph, the conventional mixes ( $A$ and $E$ ) would crack at $-38^{\circ} \mathrm{C}$, while the various recycled mixes would crack at temperatures between $-38^{\circ} \mathrm{C}$ and $-50^{\circ} \mathrm{C}$.

Kandhal (45) has stated that mixtures with high ductility values,

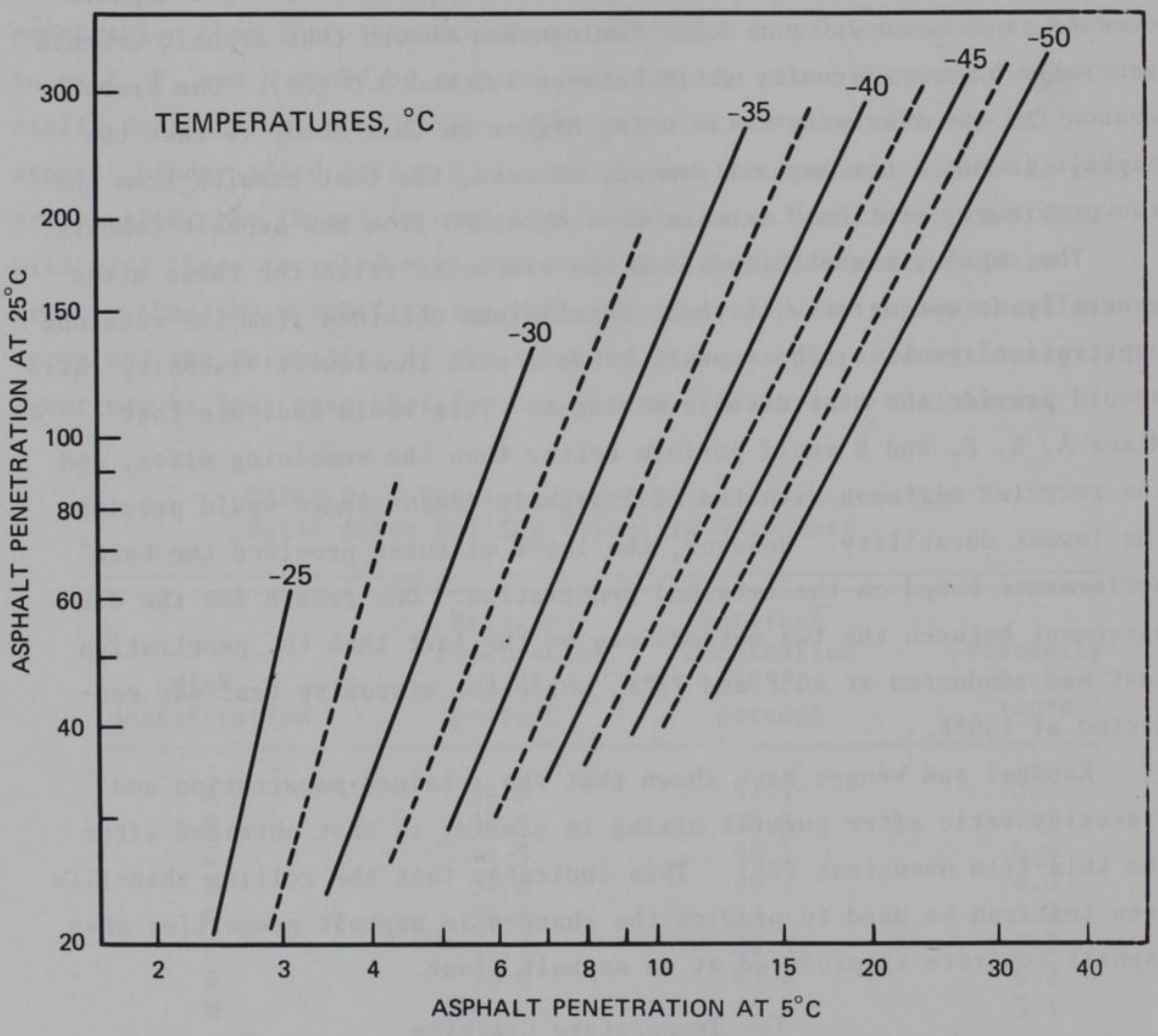

FIG. 32.--Model for Determining Temperature at Which Asphalt Concrete Will Crack During First Year (after Gaw 1976 (39)) 
TABLE 22.--Temperature at Which Cracking Will

Occur Based on Gaw Nomograph

\begin{tabular}{cc}
\hline $\begin{array}{c}\text { Mix } \\
\text { Identification }\end{array}$ & $\begin{array}{c}\text { Temperature at } \\
\text { Which Cracking } \\
\text { Will Occur }\end{array}$ \\
\hline A & $-380^{\circ} \mathrm{C}$ \\
B & $-40^{\circ} \mathrm{C}$ \\
C & $-40^{\circ} \mathrm{C}$ \\
D & $-50^{\circ} \mathrm{C}$ \\
E & $-38{ }^{\circ} \mathrm{C}$ \\
F & $-43{ }^{\circ} \mathrm{C}$ \\
G & $-50^{\circ} \mathrm{C}$ \\
H & $-38^{\circ} \mathrm{C}$ \\
\hline
\end{tabular}

* Descriptions of Mixes A-H are provided in Table 8.

when measured at low temperatures, are less susceptible to cracking than mixtures with low ductility values at this same temperature. This is reasonable since the ductility is an indication of brittleness of an asphalt binder and, thus, an indicator of potential cracking that may occur during the performance life of the pavement. The asphalt binder recovered from samples of the laboratory prepared asphalt mixtures had ductility values between 3 and 6 at $40^{\circ} \mathrm{F}$ (Table 11). This small variation in ductility does not allow conclusions to be drawn from the test results concerning differences in quality of the various combined asphalt cements. The results do indicate that for the ductility test to be beneficial, it must be conducted at a higher temperature (for instance, $50^{\circ} \mathrm{F}$ ), where the spread in ductility values between various asphalt concretes would be greater.

McLeod (54) has shown that a satisfactory penetration of the asphalt at $77^{\circ} \mathrm{F}$ and a satisfactory PVN are necessary to ensure good performance at low temperatures. The higher PVN values describe an asphalt cement with lower temperature susceptibility and, thus, a higher potential for satisfactory performance. The computed PVN values (Table 23) indicate that Mixes $B$ and $G$ would provide the least temperature-susceptible mixtures while Mixes $\mathrm{C}, \mathrm{F}$, and $\mathrm{H}$ are more temperature susceptible. The initial penetration can be controlled during the mix design; however, the PVN is apparently inherent in the materials and cannot be directly 
Table 23.--PVN Values for the Asphalt Binders Used in this Study

\begin{tabular}{cccc}
\hline $\begin{array}{c}\text { Mix* } \\
\text { Identification }\end{array}$ & $\begin{array}{c}\text { Original } \\
\text { Blended } \\
\text { Asphalt }\end{array}$ & $\begin{array}{c}\text { Asphalt from } \\
\text { Rolling Thin-Film } \\
\text { Oven Test }\end{array}$ & $\begin{array}{c}\text { Asphalt } \\
\text { Extracted from } \\
\text { Asphalt Mixtures }\end{array}$ \\
\hline A & -0.3 & -0.3 & -0.7 \\
B & +0.6 & +0.6 & 0.0 \\
C & -0.8 & -0.9 & -1.0 \\
D & -0.4 & -0.2 & -0.2 \\
E & -0.3 & -0.3 & +0.2 \\
F & -1.0 & -0.9 & -1.0 \\
G & -0.2 & +0.2 & +0.3 \\
H & -0.8 & -1.0 & -1.0 \\
\hline
\end{tabular}

* Descriptions of Mixes A-H are provided in Table 8 .

controlled during mix design. Table 23 shows that the original blended asphalt, the asphalt after the rolling thin-film oven test, and the asphalt extracted from the asphalt mixtures usually had approximately equal PVN values for a particular mix. The type of recycling agent selected for use in the recycled mixture can modify the PVN of the existing binder. The data in Table 23 show that the use of the recycling agent produced a different PVN than that produced with the AC-5 cement.

Tests conducted by Anderson and Dukatz showed that the PVN of asphalt cements is typically between -0.3 and -1.5 (14). The PVN of the combined asphalt cement for the recycled mixtures produced with AC-5 asphalt cement was generally above -0.3 which indicates these recycled mixtures are less temperature susceptible than typical conventional mixtures. The PVN of the asphalt from the other recycled mixtures and conventional mixtures was generally between -0.3 and -1.5 .

Another important property that relates to the low temperature cracking of asphalt concrete is the amount of tensile strain the mixture can undergo prior to failure. The tensile strain at failure for a given asphalt mixture is easily measured with the indirect tensile test. Since low temperature cracking results from shrinkage of the asphalt concrete, a low tolerance for strain results in an increase in low temperature cracking.

Analysis of the data indicates that the strain at failure is relate: 
to penetration (Fig. 33). A regression analysis of the data showed

$$
\text { S. F. }=-0.00053+0.00287 \log \mathrm{PN}
$$

where

$$
\begin{aligned}
\text { S. } & \text {. }=\text { strain at failure } \\
\text { PN } & =\text { asphalt penetration }
\end{aligned}
$$

The coefficient of determination for this equation is 0.836 . The asphalt penetration used in this formula was determined for the asphalt binder recovered from the asphalt mixture and tested at the temperature at which the strain at failure was determined. This relationship demonstrates the need to use a high penetration asphalt binder to prevent low temperature cracking.

A similar relationship between the strain at failure and the stiffness modulus was developed from the indirect tensile test results (Fig. 34). The equation for strain at failure as a function of stiffness modulus was determined from the following general linear model:

$$
\log (S . F .)=A+B \log (E)
$$

where

$$
\begin{aligned}
\text { S. F. } & =\text { strain at failure } \\
E & =\text { stiffness modulus }
\end{aligned}
$$

Solving the regression for $A$ and $B$ and taking the inverse log of both sides of the equation result in the model below:

$$
\text { S. } F .=0.375(E)^{-0.442}
$$

This model has a coefficient of determination of 0.955 . The model indicates that an increase in mixture stiffness will result in a decrease in strain at failure and vice versa. Hence, the potential for temperature cracking in a mixture is decreased by reducing the mixture stiffness.

\section{Water Susceptibility Results}

The adverse effect of water often causes early failure of many 


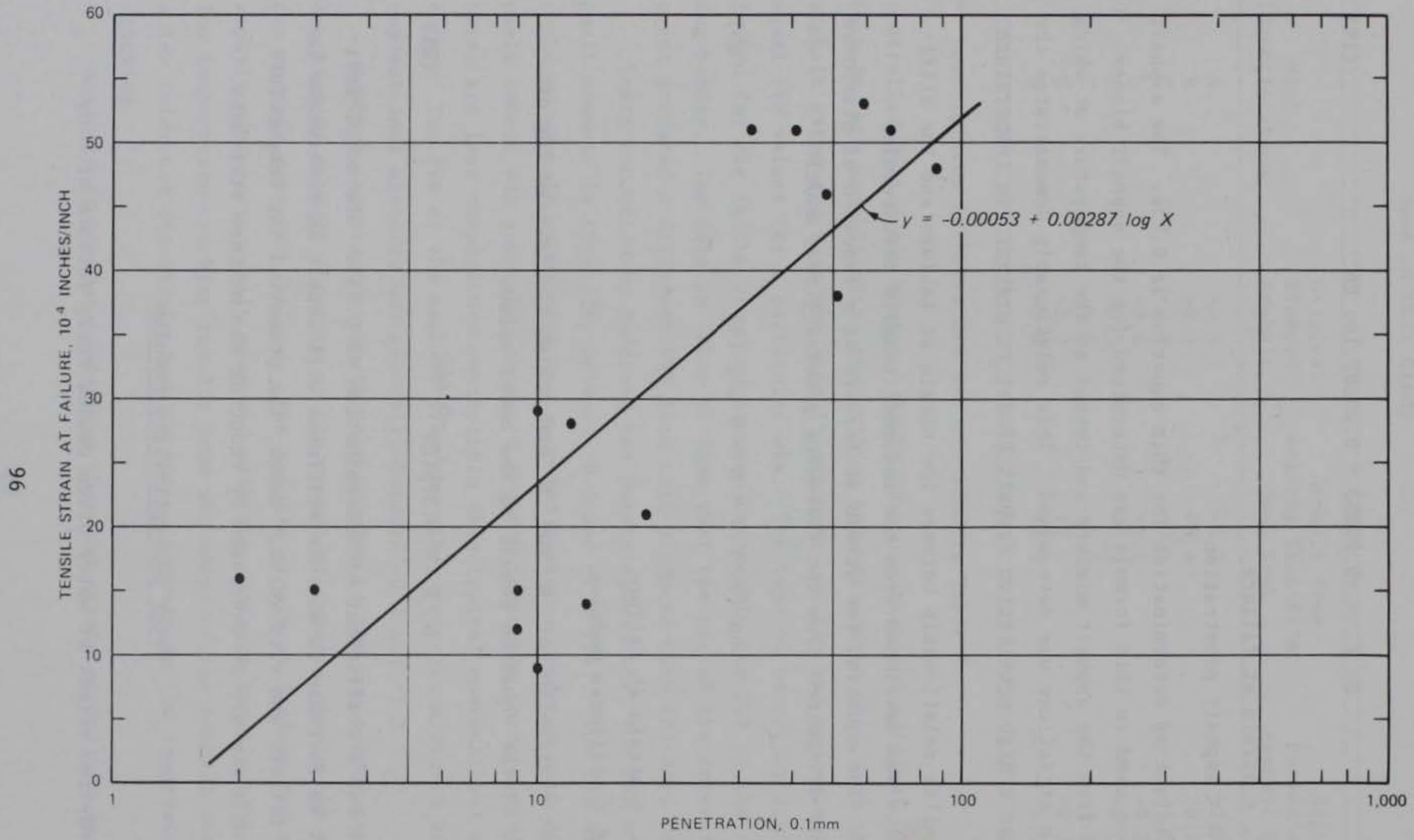

FIG. 33.--Relationship Between Tensile Strain at Failure and Asphalt Penetration 


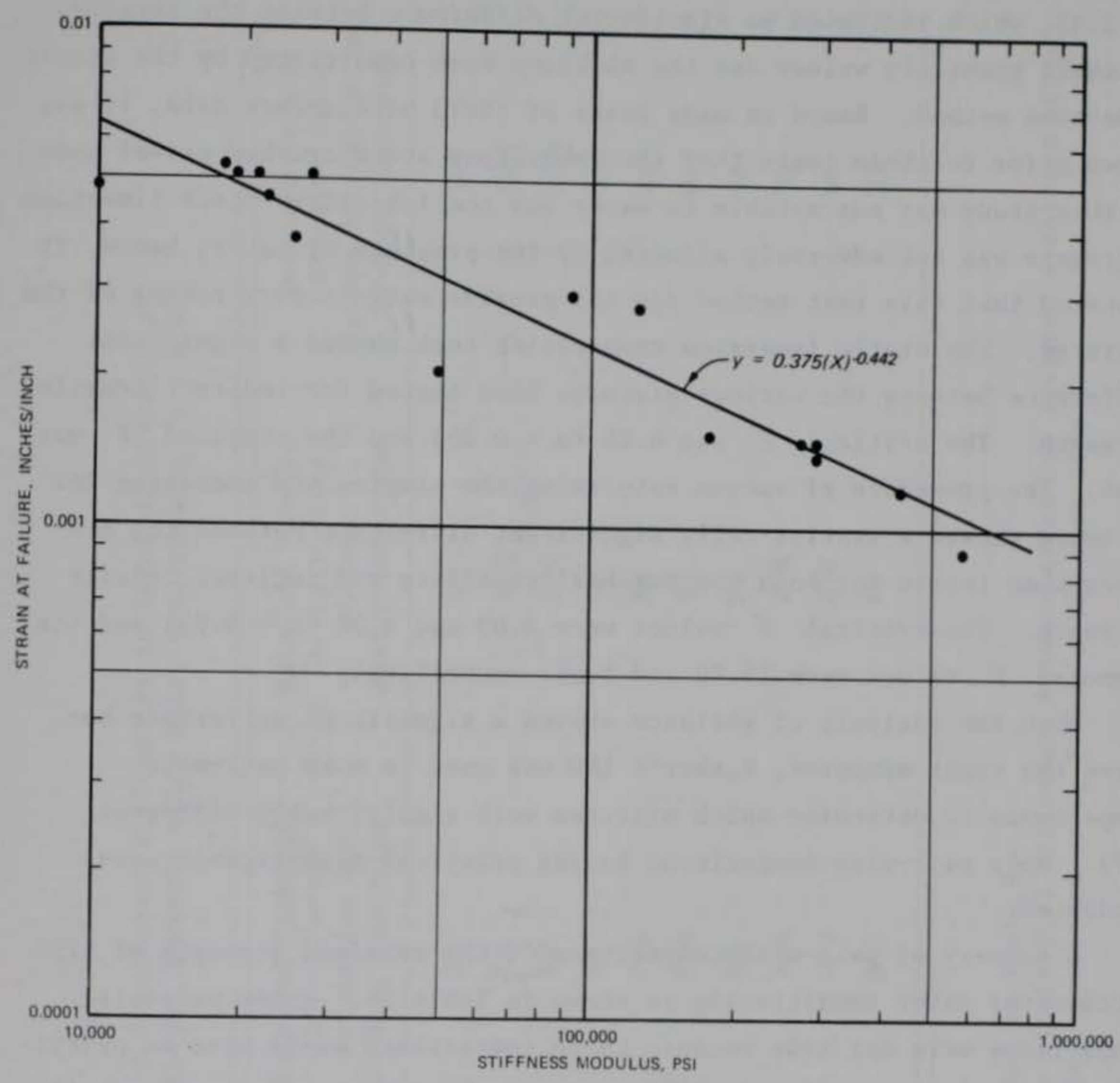

FIG. 34.--Relationship Between Tensile Strain at Failure and Stiffness Modulus

bituminous concrete mixtures. Two water conditioning procedures (static immersion, and vacuum saturation and immersion) were used to condition the mixtures, and two test procedures (Marshall stability and indirect tensile strength) were used to quantitatively measure the effects of water on each of the asphalt concrete mixtures. The results of these tests are shown in Tables 12, 15, and 16.

An analysis of variance of the test results after water conditioning was conducted to determine if the test measured a significant difference between the various asphalt mixtures (57). The analysis of variance showed a critical $F$ equal to $4.03(\alpha=0.05)$ and a computed $F$ equal 
to 2.33 , which indicated no significant difference between the retained Marshall stability values for the mixtures when conditioned by the static immersion method. Based on many years of field performance data, it was known prior to these tests that the laboratory stock crushed gravel used in this study was susceptible to water and the laboratory stock limestone aggregate was not adversely affected by the presence of water; hence, it appeared that this test method did not provide satisfactory rating of the mixtures. The static immersion compression test showed a significant difference between the various mixtures when tested for indirect tensile strength. The critical $F$ was $4.28(\alpha=0.05)$ and the computed $F$ was 5.04. The procedure of vacuum saturating the samples and immersing for 24 hours showed a statistically significant difference between the mixtures when tested for both the Marshall stability and indirect tensile strength. The critical $F$ values were 4.03 and $4.28(\alpha=0.05)$ and the computed $F$ values were 19.90 and 5.56 , respectively.

When the analysis of variance showed a significant difference between the eight mixtures, Fisher's LSD was used to make pair-wise comparisons to determine which mixtures were significantly different (57). Unly pair-wise comparisons having practical significance were conducted.

A summary of pair-wise comparisons of the retained strength of mixtures after water conditioning is shown in Table 24. Other pair-wise comparisons were not made because these comparisons would have no practical engineering significance. A review of the four sets of test results showed very little agreement among the methods. The retained stability after 24-hour static immersion did not show a significant difference between the various mixtures. The retained tensile strength for both water conditioning methods often showed a slight drop or an increase in tensile strength after being conditioned in water (Tables 15 and 16). The retained stability after vacuum saturation and 24-hour immersion always showed a decrease in stability after water conditioning (Table 12). In this case, the retained stabilities for mixtures prepared with the crushed gravel were considerably lower than the retained stabilities for the mixtures prepared with limestone aggregates. The results after vacuum saturation and 24-hour immersion correlate with performance of these mixtures in the field. It, therefore, appears that the best 
TABLE 24.--Summary of Significant Differences in Retained Strength of Recycled and Conventional Mixtures After Water Conditioning $(\alpha=0.05)$

\begin{tabular}{|c|c|c|c|c|}
\hline $\begin{array}{l}\text { Mixes* } \\
\text { Compared }\end{array}$ & $\begin{array}{c}\text { Retained Stability } \\
\text { After 24-Hour } \\
\text { Static Immersion }\end{array}$ & $\begin{array}{l}\text { Retained Stability } \\
\text { After Vacuum } \\
\text { Saturation and } \\
\text { 24-Hour Immersion }\end{array}$ & $\begin{array}{c}\text { Retained Tensile } \\
\text { Strength After } \\
\text { 24-Hour } \\
\text { Static Immersion }\end{array}$ & $\begin{array}{l}\text { Retained Tensile } \\
\text { Strength After } \\
\text { Vacuum Saturation and } \\
\text { 24-Hour Immersion }\end{array}$ \\
\hline$A$ and $B$ & NS & NS & NS & NS \\
\hline$A$ and $C$ & NS & NS & $A>C$ & $\mathrm{C}>\mathrm{A}$ \\
\hline$B$ and $C$ & NS & NS & $B>C$ & $\mathrm{C}>\mathrm{B}$ \\
\hline$D$ and $E$ & NS & NS & NS & NS \\
\hline$F$ and $E$ & NS & $F>E$ & NS & NS \\
\hline$D$ and $F$ & NS & $F>D$ & NS & $\mathrm{D}>\mathrm{F}$ \\
\hline$G$ and $E$ & NS & NS & NS & NS \\
\hline $\mathrm{H}$ and $\mathrm{E}$ & NS & $\mathrm{H}>\mathrm{E}$ & $\mathrm{E}>\mathrm{H}$ & NS \\
\hline$G$ and $H$ & NS & $\mathrm{H}>\mathrm{G}$ & $\mathrm{G}>\mathrm{H}$ & NS \\
\hline$A$ and $E$ & NS & $A>E$ & NS & NS \\
\hline
\end{tabular}

NOTE: NS $=$ No significant difference.

* Descriptions of Mixes A-H are provided in Table 8.

** Since analysis of variance showed no statistical difference between mixes for retained stability after 24-hour static immersion, no pair-wise comparisons using Fisher's LSD were made. 
procedure of the four techniques used for this study is to vacuum saturate the samples, immerse in water for 24 hours, and measure the retained stability. This procedure indicates that the conventional mixture with crushed limestone (Mix A) performed better than the conventional mixture with crushed gravel (Mix E). Also, the recycled Mixes $\mathrm{F}$ and $\mathrm{H}$ performed better than the corresponding conventional Mix E. The recycled Mixes $\mathrm{F}$ and $\mathrm{H}$ which used recycling agent performed better than the corresponding recycled Mixes $D$ and $G$ which used $A C-5$ as the new asphalt binder. The retained stabilities for Mixes D, E, and G were lower than 50 percent, which is often recommended as the minimum allowable value in evaluating bituminous mixtures. Based on these results, the recycling agent appeared to improve the resistance of recycled Mixes $\mathrm{F}$ and $\mathrm{H}$ to the adverse effects of water.

\section{Analysis of Fatigue}

A review of Figs. 22, 23, 26, 27, 30, and 31 indicates that a mixture strain of $0.0001 \mathrm{in./in.} \mathrm{results} \mathrm{in} \mathrm{approximately} 1,000,000$ cycles to failure for most mixtures at $77^{\circ} \mathrm{F}$ and $40^{\circ} \mathrm{F}$. The only mixtures that appear to deviate significantly from this are Mix $\mathrm{C}$ at $77^{\circ} \mathrm{F}$ and $\mathrm{Mix} \mathrm{H}$ at $40^{\circ} \mathrm{F}$. This seems to indicate that a strain of $0.0001 \mathrm{in.} / \mathrm{in}$, in an asphalt concrete mixture produces as much damage to the mixture at $77^{\circ} \mathrm{F}$ as it does to the mixture at $40^{\circ} \mathrm{F}$. At higher strains such as $0.001 \mathrm{in}$./ in., the mixtures at $77^{\circ} \mathrm{F}$ clearly outperform the mixtures at $40^{\circ} \mathrm{F}$. Based on these flexural fatigue tests, the tensile strain in an asphalt mixture should be kept below $0.0001 \mathrm{in.Jin.} \mathrm{to} \mathrm{ensure} \mathrm{more} \mathrm{than} \mathrm{1,000,000} \mathrm{cycles}$ to failure at either temperature investigated.

Statistical procedures were used to determine if there was evidence to support a significant difference between the recycled mixtures and the conventional mixtures for the models shown in Figs, 20-31. The analysis of covariance (57) is used to determine the effect caused by treatment such as mixture type along with the effect caused by an independent variable such as bending stress or initial bending strain. By using a dummy variable, a general linear model can be written that includes the effect of treatment along with the effect of the independent variable. In this 
case, for comparison of a conventional mixture and a recycled mixture, the general linear model would be

$$
\mathrm{Y}=\mathrm{B}_{0}+\mathrm{B}_{1} \mathrm{X}_{1}+\mathrm{B}_{2} \mathrm{X}_{2}+\mathrm{B}_{3} \mathrm{X}_{1} \mathrm{X}_{2}
$$

where

$$
\text { } \begin{aligned}
\mathrm{B}_{0}, \mathrm{~B}_{1}, \mathrm{~B}_{2}, \text { and } \mathrm{B}_{3} & =\text { constants } \\
\mathrm{X}_{1} & =\text { bending stress or initial bending strain } \\
\mathrm{X}_{2} & =1 \text { if recycled mixture; } \mathrm{x}_{2}=0 \text { otherwise }
\end{aligned}
$$

Hence, the equation to determine the cycles to failure for the conventional mixture becomes

$$
\mathrm{Y}=\mathrm{B}_{0}+\mathrm{B}_{1} \mathrm{X}_{1}
$$

and the equation to determine the cycles to failure for the recycled mixture becomes

$$
\mathrm{Y}=\left(\mathrm{B}_{0}+\mathrm{B}_{2}\right)+\left(\mathrm{B}_{1}+\mathrm{B}_{3}\right) \mathrm{X}_{1}
$$

To determine if the slopes of the best-fit lines for the two mixtures are significantly different, the null hypothesis $B_{3}=0$ was used. If there was insufficient evidence based on the F-statistic to reject the hypothesis that $B_{3}=0$, then the slope, in this case $B_{1}$, of the two lines was considered to be the same for the two mixtures. If there was sufficient evidence to reject the hypothesis $B_{3}=0$, then the slopes of the two lines were considered to be different.

If there was insufficient evidence to reject the hypothesis $B_{3}$ $=0$, then the null hypothesis $B_{2}=0$ was evaluated to determine if there was a significant difference in the intercept for the best-fit lines for the mixtures being compared. If sufficient evidence existed to reject the hypothesis $B_{2}=0$, then the intercept was considered to be different for the mixtures evaluated. This technique was used to compare each of the recycled mixtures to the corresponding conventional mixture. A summary of computed $F$ values used to determine if there was a significant difference (at $\alpha=0.01$ level) in slope or intercept between the mixtures evaluated is shown in Table 25 . When the critical $F$ value 
TABLE 25.--F Values to Determine Significant Difference in Slope and Intercept of Recycled Mixtures and Conventional

Mixtures for $\alpha=0.01$

\begin{tabular}{|c|c|c|c|c|c|c|}
\hline \multirow{2}{*}{$\begin{array}{c}\text { Mixes* } \\
\text { Compared }\end{array}$} & \multirow{2}{*}{\multicolumn{2}{|c|}{ Mode of Comparison }} & \multicolumn{2}{|c|}{$\begin{array}{l}\mathrm{H}_{0}: \mathrm{B}_{3}=0 \\
\text { Same Slope }\end{array}$} & \multicolumn{2}{|c|}{$\begin{array}{c}\mathrm{H}_{0}: \mathrm{B}_{2}=0 \\
\text { Same Intercept }\end{array}$} \\
\hline & & & F & $\begin{array}{c}\text { Critical } \\
\text { Value }\end{array}$ & F & $\begin{array}{c}\text { Critical } \\
\text { Value }\end{array}$ \\
\hline \multirow[t]{4}{*}{$B$ and $A$} & Bending Stress $-77^{\circ} \mathrm{F}$ & & 3.69 & 8.40 & 0.96 & 8.29 \\
\hline & Bending Stress $-40^{\circ} \mathrm{F}$ & & 0.12 & 8.29 & 12.04 & 8.18 \\
\hline & Initial Bending Strain & $-77^{\circ} \mathrm{F}$ & 0.32 & 8.40 & 53.72 & 8.29 \\
\hline & Initial Bending Strain & $-40^{\circ} \mathrm{F}$ & 5.44 & 8.29 & 10.06 & 8.18 \\
\hline \multirow[t]{4}{*}{$C$ and $A$} & Bending Stress $-77^{\circ} \mathrm{F}$ & & 7.58 & 8.53 & 36.53 & 8.40 \\
\hline & Bending Stress $-40^{\circ} \mathrm{F}$ & & 1.36 & 8.40 & 24.26 & 8.29 \\
\hline & Initial Bending Strain & $-77^{\circ} \mathrm{F}$ & 3.08 & 8.53 & 0.03 & 8.40 \\
\hline & Initial Bending Strain & $-40^{\circ} \mathrm{F}$ & 2.92 & 8.40 & 3.20 & 8.29 \\
\hline \multirow[t]{4}{*}{$D$ and $E$} & Bending Stress $-77^{\circ} \mathrm{F}$ & & 0.10 & 8.40 & 0.24 & 8.29 \\
\hline & Bending Stress $-40^{\circ} \mathrm{F}$ & & 1.87 & 8.40 & 55.16 & 8.29 \\
\hline & Initial Bending Strain & $-77^{\circ} \mathrm{F}$ & 0.33 & 8.40 & 1.00 & 8.29 \\
\hline & Initial Bending Strain & $-40^{\circ} \mathrm{F}$ & 0.40 & 8.40 & 0.29 & 8.29 \\
\hline \multirow[t]{4}{*}{$\mathrm{F}$ and $\mathrm{E}$} & Bending Stress $-77^{\circ} \mathrm{F}$ & & 1.37 & 8.68 & 0.00 & 8.53 \\
\hline & Bending Stress $-40^{\circ} \mathrm{F}$ & & 0.28 & 8.40 & 11.51 & 8.29 \\
\hline & Initial Bending Strain & $-77^{\circ} \mathrm{F}$ & 0.55 & 8.68 & 2.68 & 8.53 \\
\hline & Initial Bending Strain & $-40^{\circ} \mathrm{F}$ & 0.13 & 8.40 & 0.48 & 8.29 \\
\hline \multirow[t]{4}{*}{$\mathrm{G}$ and $\mathrm{E}$} & Bending Stress $-77^{\circ} \mathrm{F}$ & & 0.00 & 8.53 & 0.02 & 8.40 \\
\hline & Bending Stress $-40^{\circ} \mathrm{F}$ & & 2.58 & 8.68 & 84.02 & 8.53 \\
\hline & Initial Bending Strain & $-77^{\circ} \mathrm{F}$ & 3.66 & 8.53 & 3.15 & 8.40 \\
\hline & Initial Bending Strain & $-40^{\circ} \mathrm{F}$ & 1.32 & 8.68 & 7.03 & 8.53 \\
\hline \multirow[t]{4}{*}{$H$ and $E$} & Bending Stress $-77^{\circ} \mathrm{F}$ & & 0.37 & 8.29 & 33.02 & 8.18 \\
\hline & Bending Stress $-40^{\circ} \mathrm{F}$ & & 0.76 & 8.53 & 180.00 & 8.40 \\
\hline & Initial Bending Strain & $-77^{\circ} \mathrm{F}$ & 0.51 & 8.29 & 5.22 & 8.18 \\
\hline & Initial Bending Strain & $-40^{\circ} \mathrm{F}$ & 0.15 & 8.53 & 44.50 & 8.40 \\
\hline
\end{tabular}

* Descriptions of Mixes A-H are provided in Table 8 . 
exceeded the computed $F$, there was insufficient evidence to reject the null hypothesis, and the null hypothesis was therefore considered to be true.

A summary of the comparisons made between conventional mixtures and recycled mixtures is shown in Table 26. Other pair-wise comparisons were not made because these comparisons would have no practical significance. A study of the data presented here and in Figs. 20, 21, 26, and 27 indicates, in general, that Mix B performed as well as Mix A in only one of the four modes of comparison. The data shown in Tables 9-11 provides information which partially explains why Mix B performed poorly in comparison to Mix A. Mix B was produced with an asphalt binder that was stiffer than the other asphalt binders as shown by the penetration, ductility, viscosity, and softening point test results. Stiff mixtures generally do not perform as well as more flexible mixtures in fatigue when evaluated as a function of strain applied to the mixture. This explains why the fatigue test results showed that Mix B did not perform as well as Mix A for initial bending strain at $40^{\circ} \mathrm{F}$ and $77^{\circ} \mathrm{F}$. Generally, stiffer mixtures perform better when evaluated against bending stress; however, in this case, Mix A outperformed Mix B at $40^{\circ} \mathrm{F}$ even though the stiffness modulus of Mix B was slightly higher. There was no significant

TABLE 26.--Summary of Significant Differences Between Fatigue Test Results of Recycled and Conventional Mixtures $(\alpha=0.01)$

\begin{tabular}{lllcc}
\hline & \multicolumn{3}{c}{ Mode of Comparison* } \\
\cline { 2 - 5 } $\begin{array}{c}\text { Mixes } * * \\
\text { Compared }\end{array}$ & $\begin{array}{c}\text { Bending } \\
\text { Stress } \\
77^{\circ} \mathrm{F}\end{array}$ & $\begin{array}{c}\text { Bending } \\
\text { Stress } \\
40^{\circ} \mathrm{F}\end{array}$ & $\begin{array}{c}\text { Initial } \\
\text { Bending Strain } \\
77^{\circ} \mathrm{F}\end{array}$ & $\begin{array}{c}\text { Initial } \\
\text { Bending Strain } \\
40^{\circ} \mathrm{F}\end{array}$ \\
\hline $\mathrm{B}$ and A & NS & SI & SI & SI \\
$\mathrm{C}$ and A & SI & SI & NS & NS \\
$D$ and E & NS & SI & NS & NS \\
F and E & NS & SI & NS & NS \\
G and E & NS & SI & NS & SI \\
H and E & SI & SI & NS & \\
\hline
\end{tabular}

* NS = no significant difference; SS = significant difference in slope; and $\mathrm{SI}=$ significant difference in intercept.

** Descriptions of Mixes A-H are shown in Table 8 . 
difference in performance based on bending stress at $77^{\circ} \mathrm{F}$.

Another observation that was made from Table 26 is that, in general, Mix H did not perform as well as Mix E. Mix H contained 70 percent reclaimed asphalt pavement in the recycled mixture. This high amount of RAP along with the high percentage of recycle agent used in Mix $H$ made mixing difficult, which partially explains the poor performance.

One observation that stands out more than any other is that, in every case, for bending stress at $40^{\circ} \mathrm{F}$, the conventional mixtures performed better than the recycled mixtures. This would seem to indicate that the conventional mixtures were stiffer than the recycled mixtures at $40^{\circ} \mathrm{F}$, and based on the results of the indirect tensile test conducted on the asphalt mixtures (Table 14), this generally appears to be true.

\section{Development of a Model to Predict Fatigue Performance}

The time and expense required to conduct sufficient fatigue tests to develop a satisfactory model discourages the development of a model for individual mixtures. For this reason, a model that could use easily measured properties of an asphalt concrete mixture to accurately predict the fatigue resistance of these mixtures is needed. An attempt was made to analyze the data obtained during this study to develop such a model.

Maupin (53) has shown that the stiffness measured from the indirect tensile test is related to the fatigue life of the asphalt concrete mixture. His work indicated that some simple test such as the indirect tensile test could be used to determine mixture properties and to estimate the fatigue life.

Since the fatigue test consists of applying a number of stress applications to an asphalt concrete mixture, the applied stress expressed as a percentage of the indirect tensile strength should be useful in predicting fatigue life. Since the strain to failure is also determined from the indirect tensile test, the mixture strain under repeated loading could be expressed as a percentage of this strain at failure and this value used to predict the fatigue life of a mixture. The model below was developed to determine its capability in predicting the fatigue life of the mixtures evaluated: 


$$
y=A+B X
$$

where

$$
\begin{aligned}
\mathrm{y} & =\log \text { (cycles to failure) } \\
\mathrm{A}, \mathrm{B} & =\text { constants } \\
\mathrm{X} & =\log \text { (actual stress/tensile strength) }
\end{aligned}
$$

It was determined from a regression analysis of the data that

$$
y=3.008-1.755 x
$$

The coefficient of determination, $r^{2}$, for this equation was computed to be 0.285 . In other words, the model explained 28.5 percent of the variability of $y$, and is, therefore, not considered sufficiently accurate to predict fatigue life. Further study of the data indicated that the penetration of the asphalt binder recovered from the mixtures appeared to be related to the fatigue life. The model was expanded to include a term for asphalt penetration as shown below:

$$
\mathrm{y}=\mathrm{A}+\mathrm{BX}_{1}+\mathrm{CX}_{2}
$$

where

$$
\begin{aligned}
\mathrm{y} & =\log (\text { cycles to failure) } \\
\mathrm{A}, \mathrm{B}, \mathrm{C} & =\text { constants } \\
\mathrm{X}_{1} & =\log (\text { actual stress/tensile strength) } \\
\mathrm{X}_{2} & =\log \text { (penetration of asphalt binder) }
\end{aligned}
$$

Results of a regression analysis of the data indicated that

$$
y=3.433-2.565 x_{1}-0.728 x_{2}
$$

This equation had an $r^{2}$ of 0.422 and the additional term for penetration was determined to be significant based on the $F$ statistic. The above model can be used to predict the fatigue results for constant stress; however, the accuracy is lower than desired. The indirect tensile strength and asphalt penetration must be determined at the temperature at which the number of cycles to failure is desired.

A relationship was also developed for fatigue of the asphalt 
mixtures as a function of initial strain. Initially, the model was selected to be

$$
y=A+B X
$$

where

$$
\begin{aligned}
y & =\log \text { of cycles to failure } \\
A, B & =\text { constants } \\
X & =\log \text { strain }
\end{aligned}
$$

Based on a regression analysis of the data, this model was determined to be

$$
y=-2.922-2.099 x
$$

This model which has an $r^{2}$ equal to 0.627 is a better correlation than that developed for stress. Further investigation also indicated that $\log$ penetration appeared to be related to $y$. The model was expanded to include a term for $\log$ penetration:

$$
\mathrm{y}=\mathrm{A}+\mathrm{BX}_{1}+\mathrm{CX}_{2}
$$

where

$$
\begin{aligned}
y= & \log (\text { cycles to failure) } \\
\text { A, B, } C= & \text { constants } \\
X_{1}= & \log \text { strain } \\
X_{2}= & \begin{array}{ll}
\text { log (penetration at desired temperature of fatigue } \\
\text { results }
\end{array}
\end{aligned}
$$

A regression analysis was conducted on the data for the above model and the following results were obtained:

$$
y=-5.145-2.529 x_{1}+0.631 x_{2}
$$

The $r^{2}$ for this equation was determined to be 0.750 and the $X_{2}$ term was considered to be significant based on the $F$ statistic. Based on the $r^{2}$ values, this model is considerably better than the models shown in Equations 26, 28, and 30. A plot of the predicted fatigue life versus 
actual laboratory measured fatigue life is shown in Fig. 35. This model allows the flexure fatigue life of asphalt concrete mixtures to be simply determined over a range of temperatures. Models were also developed for the prediction of cycles to failure as a function of initial strain expressed as a percentage of failure strain and $\log$ penetration, but these models had $r^{2}$ values equal to 0.546 and 0.597 .

\section{Layered Elastic Analysis of Fatigue Data}

The Shell BISAR computer program was used to predict stresses and strains within two typical pavement sections under a given load so the fatigue data could be evaluated. One of the pavement sections consisted of a subgrade, subbase course, base course, and asphalt concrete

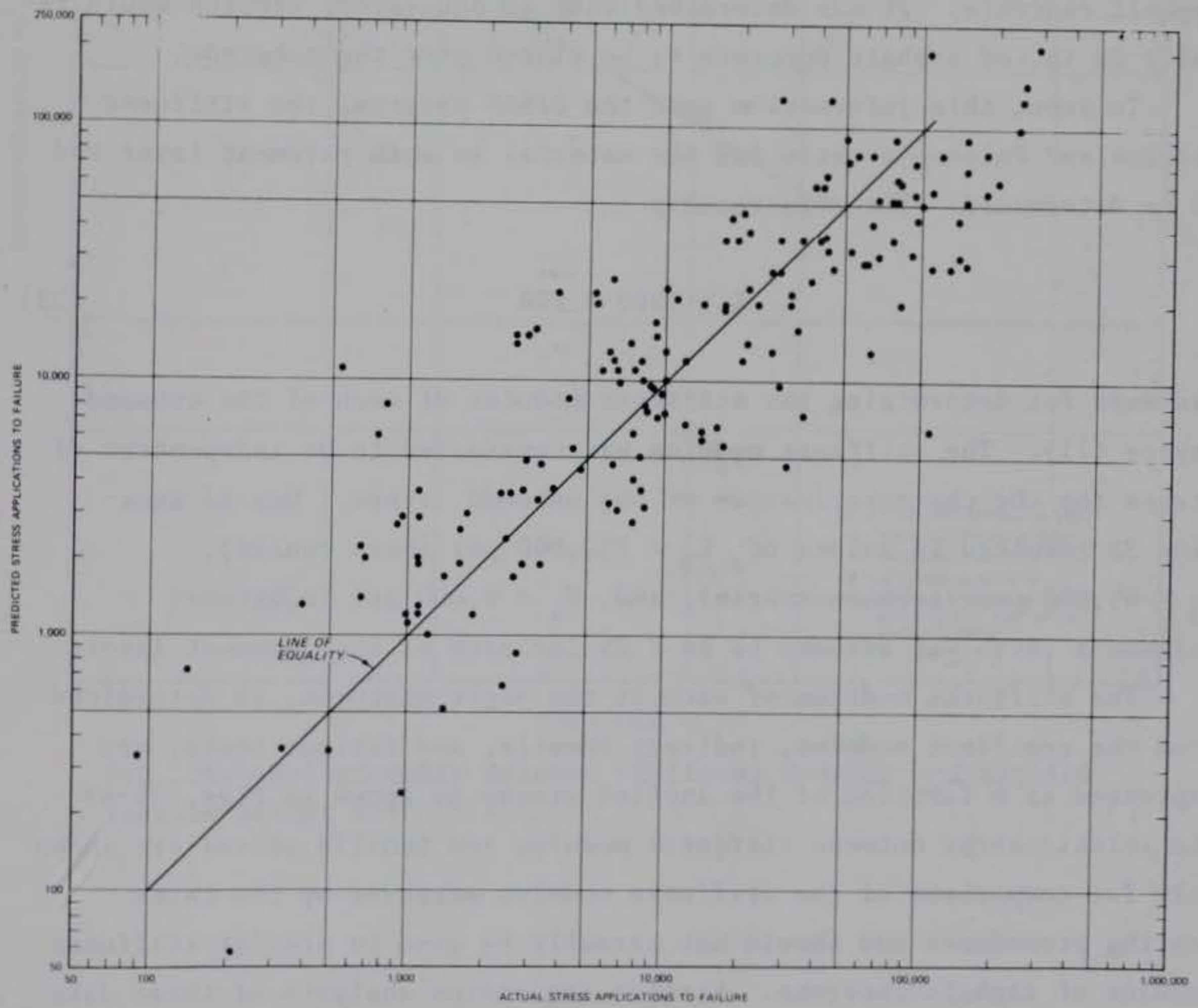

FIG. 35.--Relationship Between Predicted Number of Stress Applications and Actual Number of Stress Applications to Failure 
(four-layer pavement), and the other pavement section consisted of fulldepth asphalt concrete placed directly over the subgrade (two-layer pavement).

The Corps of Engineers criteria for airfield design were used for design of the two typical pavement sections (30). The pavement was designed for medium-load type A traffic with 50,000 passes of a design aircraft having a gross weight of 320 kips. The California Bearing Ratio (CBR) of the in-place material (subgrade) was 6 , subbase material had a CBR of 30 , and base course material had a CBR of 100 .

The pavement design for the four layer pavement resulted in $22 \mathrm{in}$. of subbase material, $7 \mathrm{in}$. of base course, and $4 \mathrm{in}$. of asphalt concrete. The second design made use of equivalency factors (30) to convert the thickness of subbase course and base course to an equivalent thickness of asphalt concrete. It was determined that an equivalent section would require $20 \mathrm{in}$. of asphalt concrete to be placed over the subgrade.

To input this information into the BISAR program, the stiffness modulus and Poisson's ratio for the material in each pavement layer had to be determined. The relationship

$$
\mathrm{E}=1500 \times \mathrm{CBR}
$$

was used for determining the stiffness modulus of each of the unbound layers (71). The stiffness modulus was considered to be independent of stress for the characterization of the unbound layers. Use of Equation 33 resulted in values of $E_{2}=150,000$ psi (base course), $\mathrm{E}_{3}=45,000 \mathrm{psi}$ (subbase course), and $\mathrm{E}_{4}=9,000 \mathrm{psi}$ (subgrade). Poisson's ratio was assumed to be 0.35 for each of the pavement layers.

The stiffness modulus of each of the eight mixtures, as determined from the resilient modulus, indirect tensile, and fatigue tests, was expressed as a function of the applied stress as shown in Figs. 36-43. The relationships between stiffness modulus and tensile stress are shown only for comparison of the stiffness modulus measured by the three testing procedures and should not normally be used to predict stiffness modulus of asphalt concrete. Since a regression analysis of these data would be misleading, it was not performed.

The BISAR computer program used the $E$ values and Poisson's ratio, 


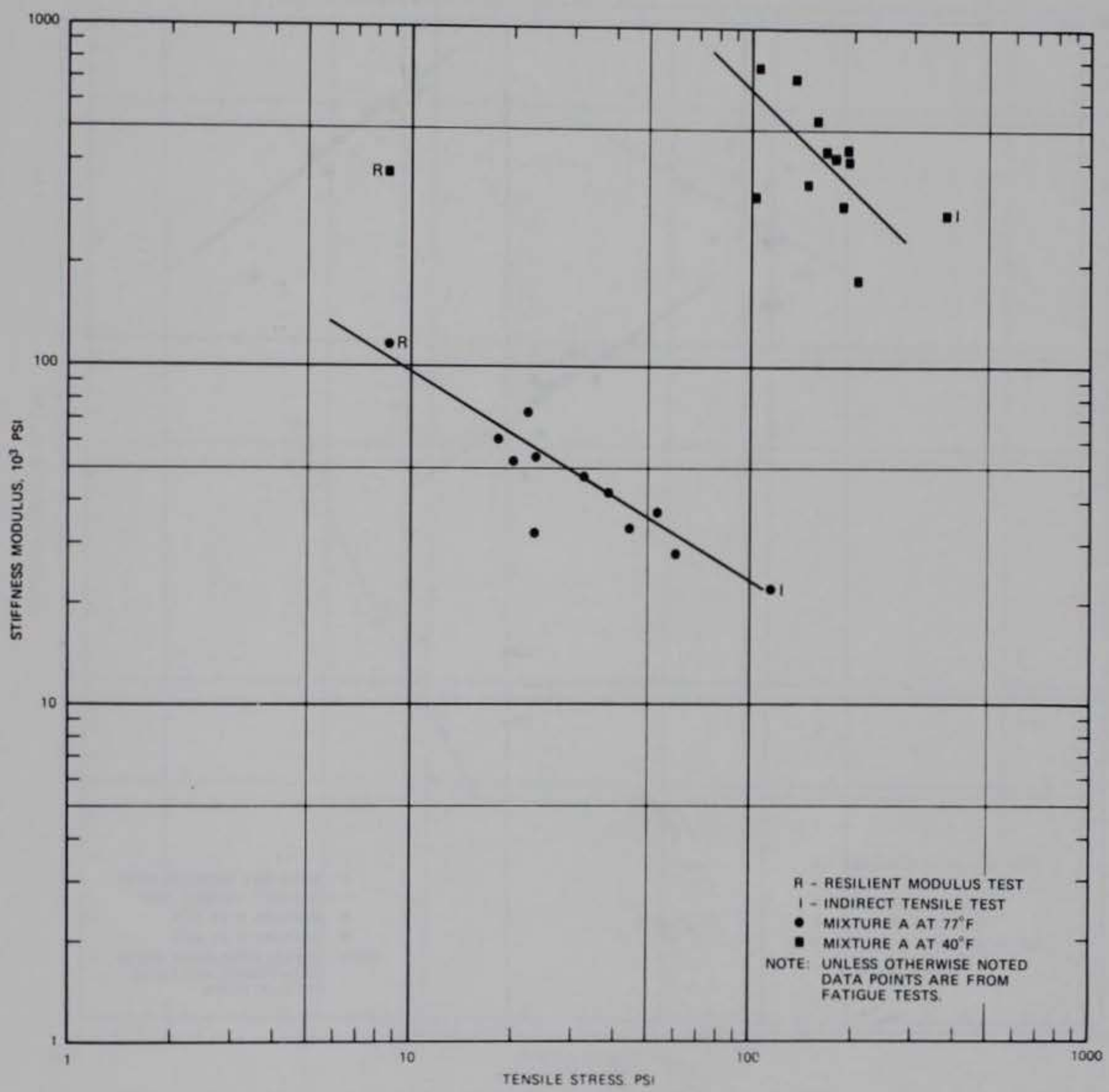

FIG. 36.--Relationship Between Stiffness Modulus and Applied Tensile Stress for Mix A 


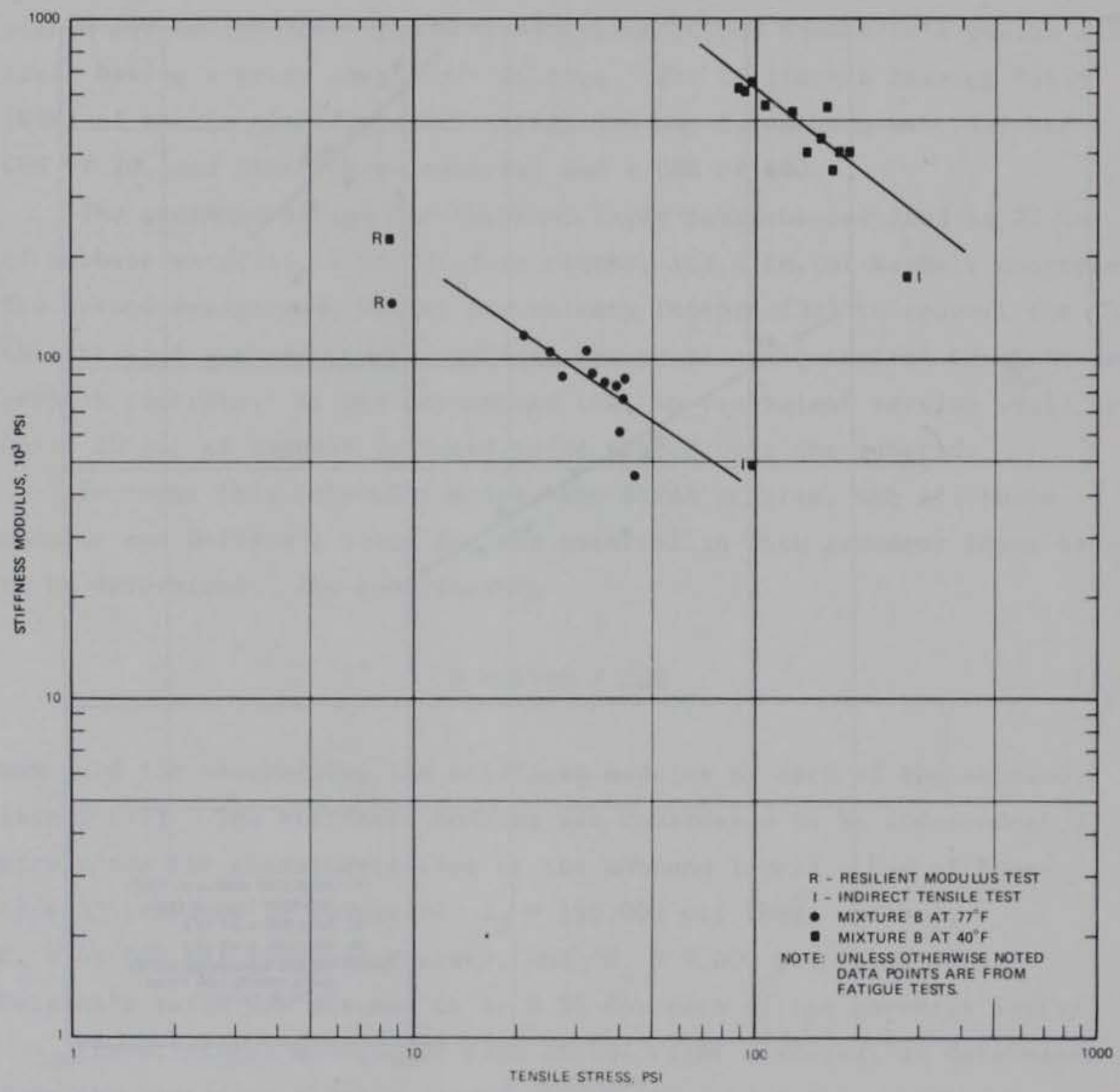

FIG. 37.--Relationship Between Stiffness Modulus and Applied Tensile Stress for Mix B 


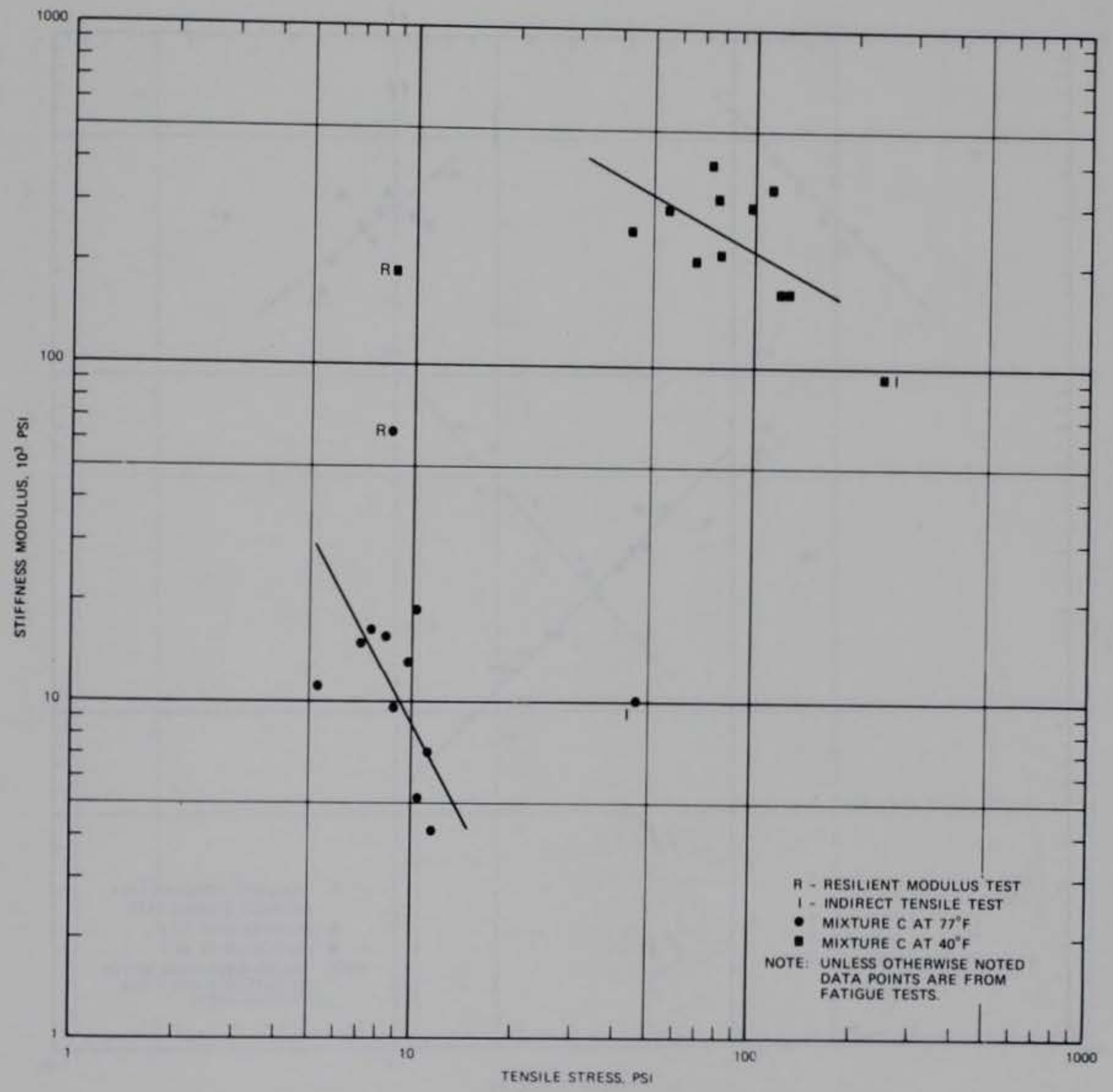

FIG. 38.--Relationship Between Stiffness Modulus and Applied Tensile Stress for Mix C 


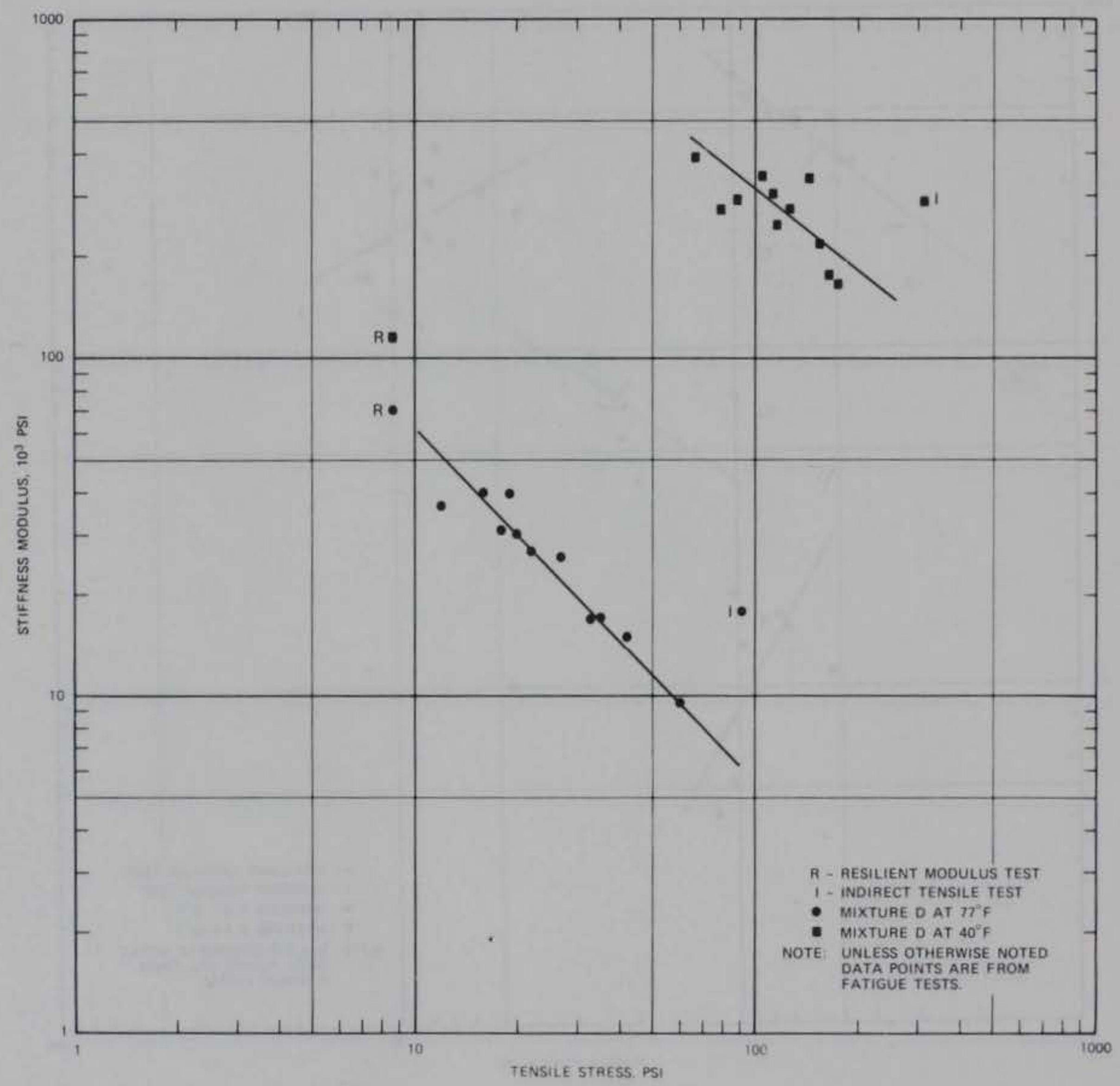

FIG. 39.--Relationship Between Stiffness Modulus and Applied Tensile Stress for Mix D 


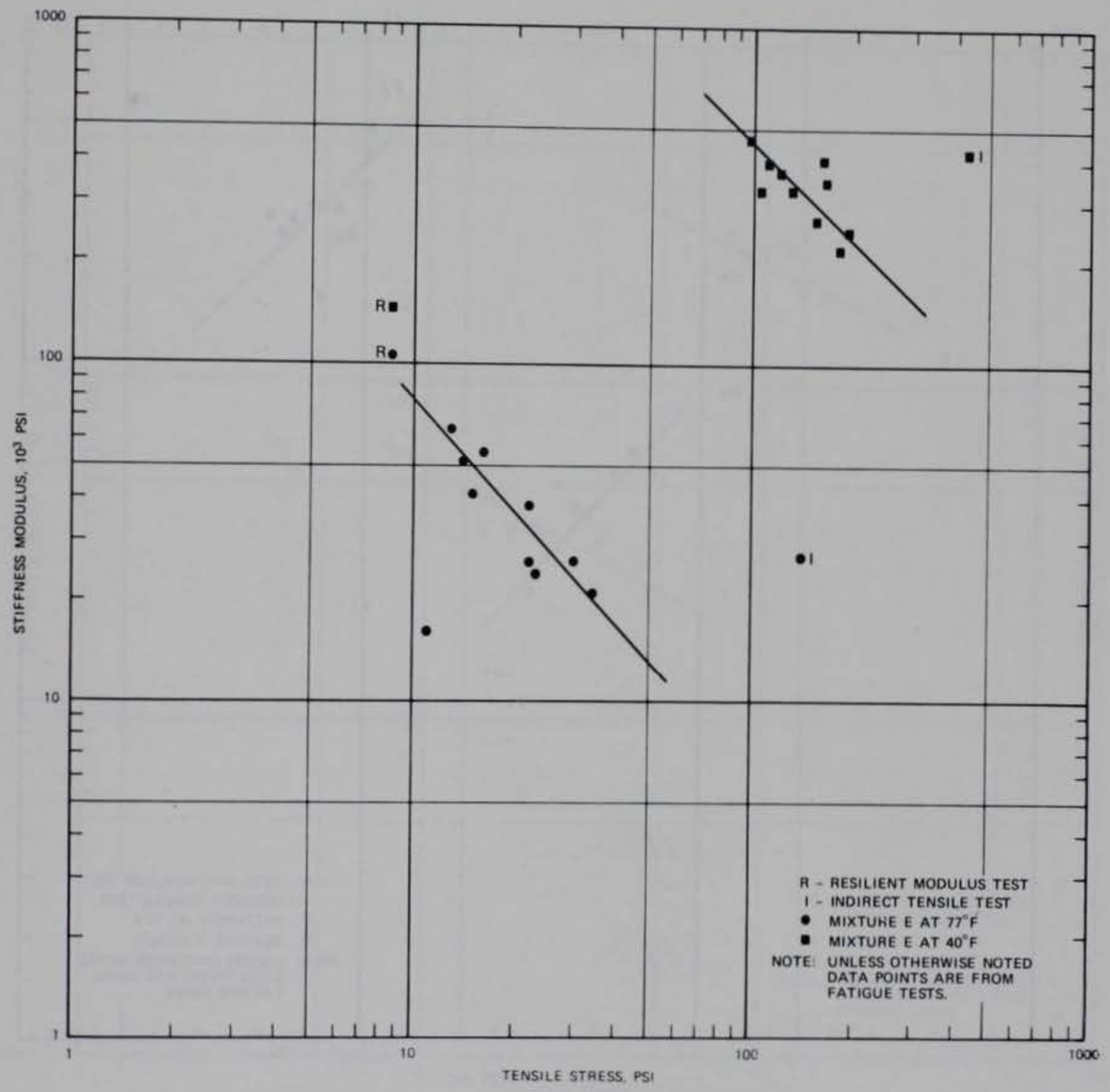

FIG. 40.--Relationship Between Stiffness Modulus and Applied Tensile Stress for Mix E 


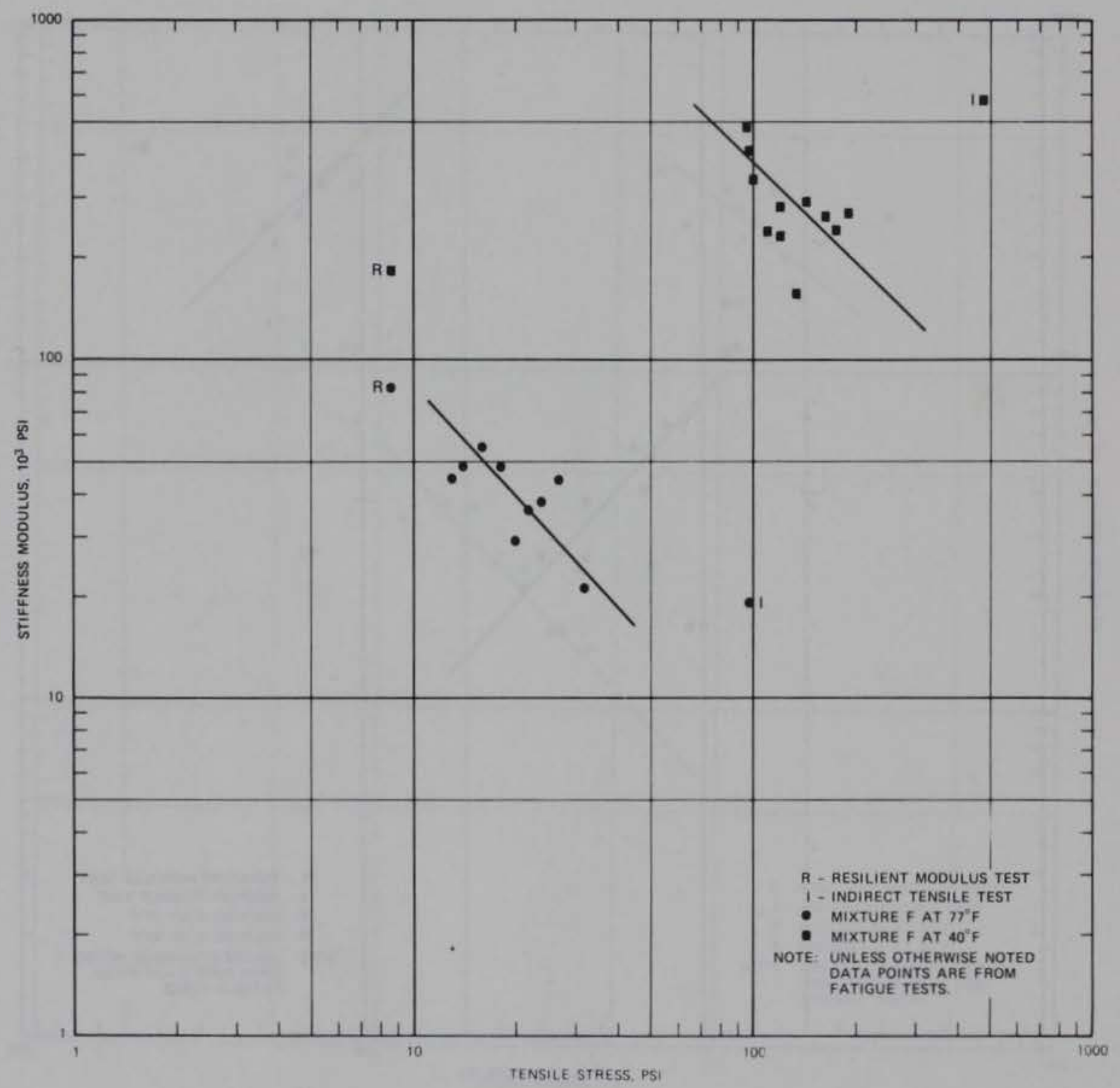

FIG. 41.--Relationship Between Stiffness Modulus and Applied Tensile Stress for Mix F 


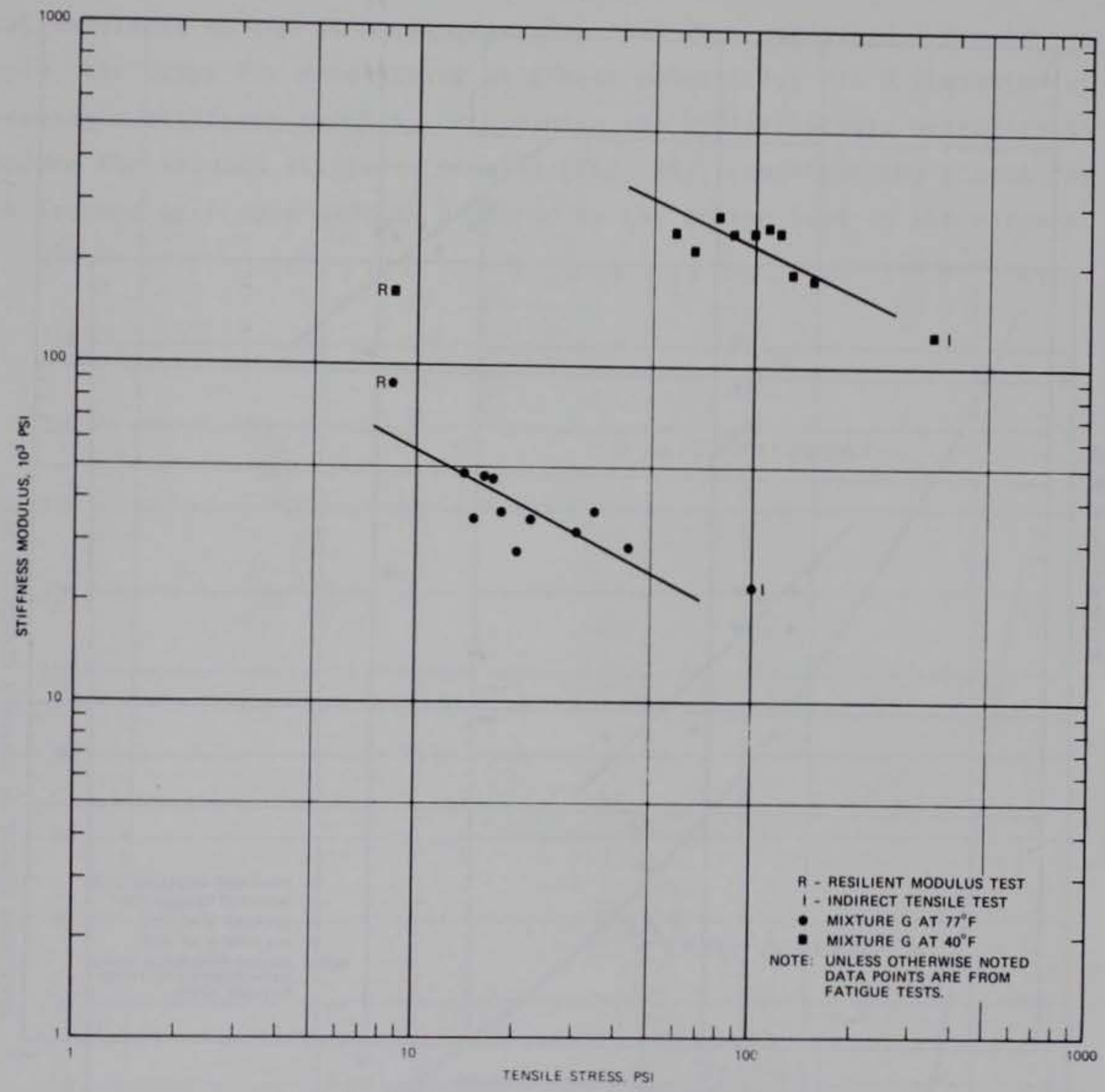

FIG. 42.--Relationship Between Stiffness Modulus and Applied Tensile Stress for Mix G

115 


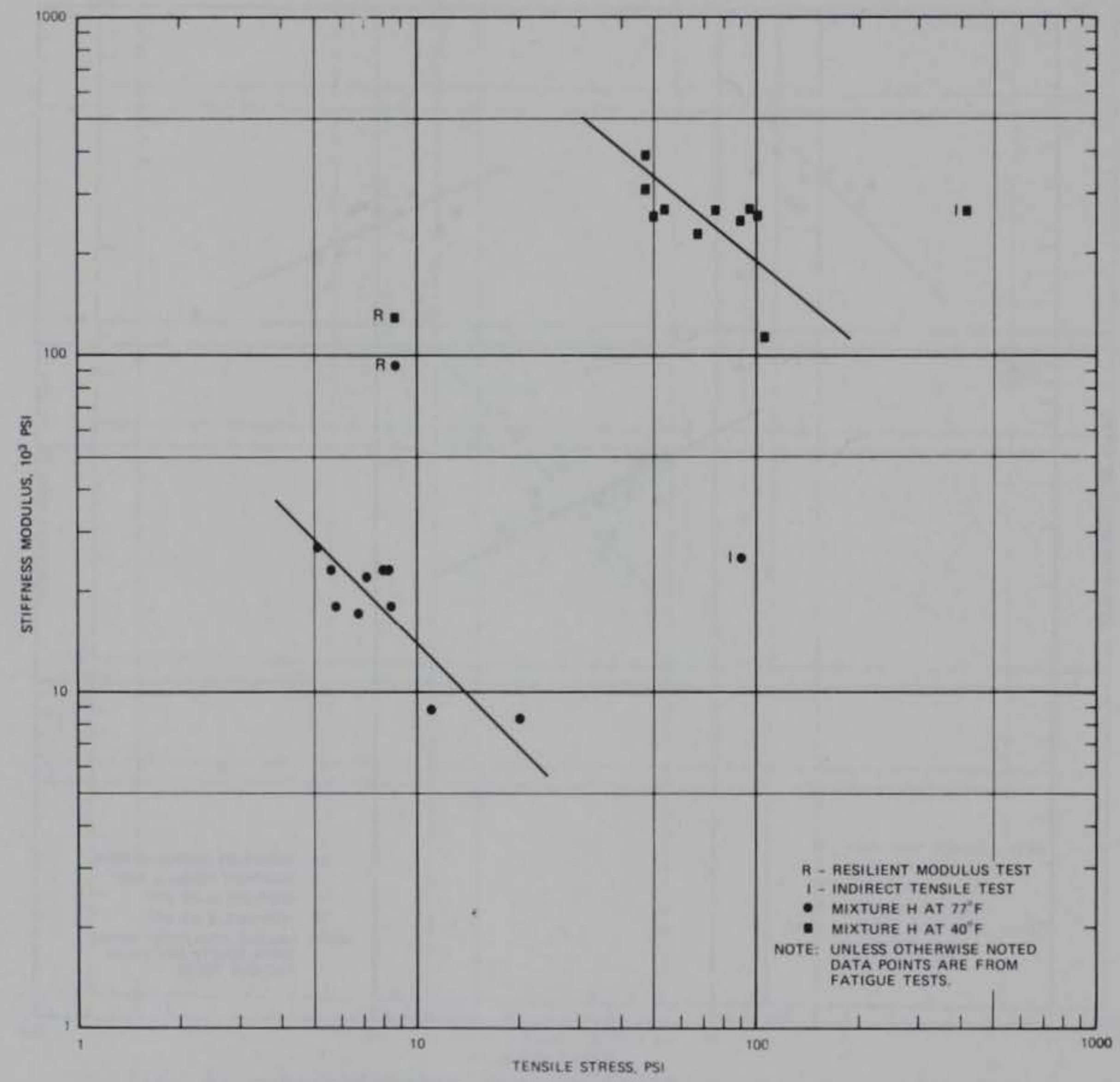

FIG. 43.--Relationship Between Stiffness Modulus and Applied Tensile Stress for Mix H 
determined above, to develop a model relating maximum tensile stress and stiffness modulus for the two typical pavement sections (Fig. 44). Since the stiffness modulus for asphalt concrete is a function of applied stress, the stiffness of the eight mixtures was selected so that the relationships developed for each of the mixtures shown in Figs. 36-43 and that developed by the BISAR program (Fig. 44) were satisfied. For example, the steps for determining stiffness modulus for Mix A consisted of assuming a stiffness modulus, determining the applied stress necessary to produce the assumed stiffness modulus (Fig. 36), computing the stress for the assumed stiffness modulus produced by the design load on the pavement

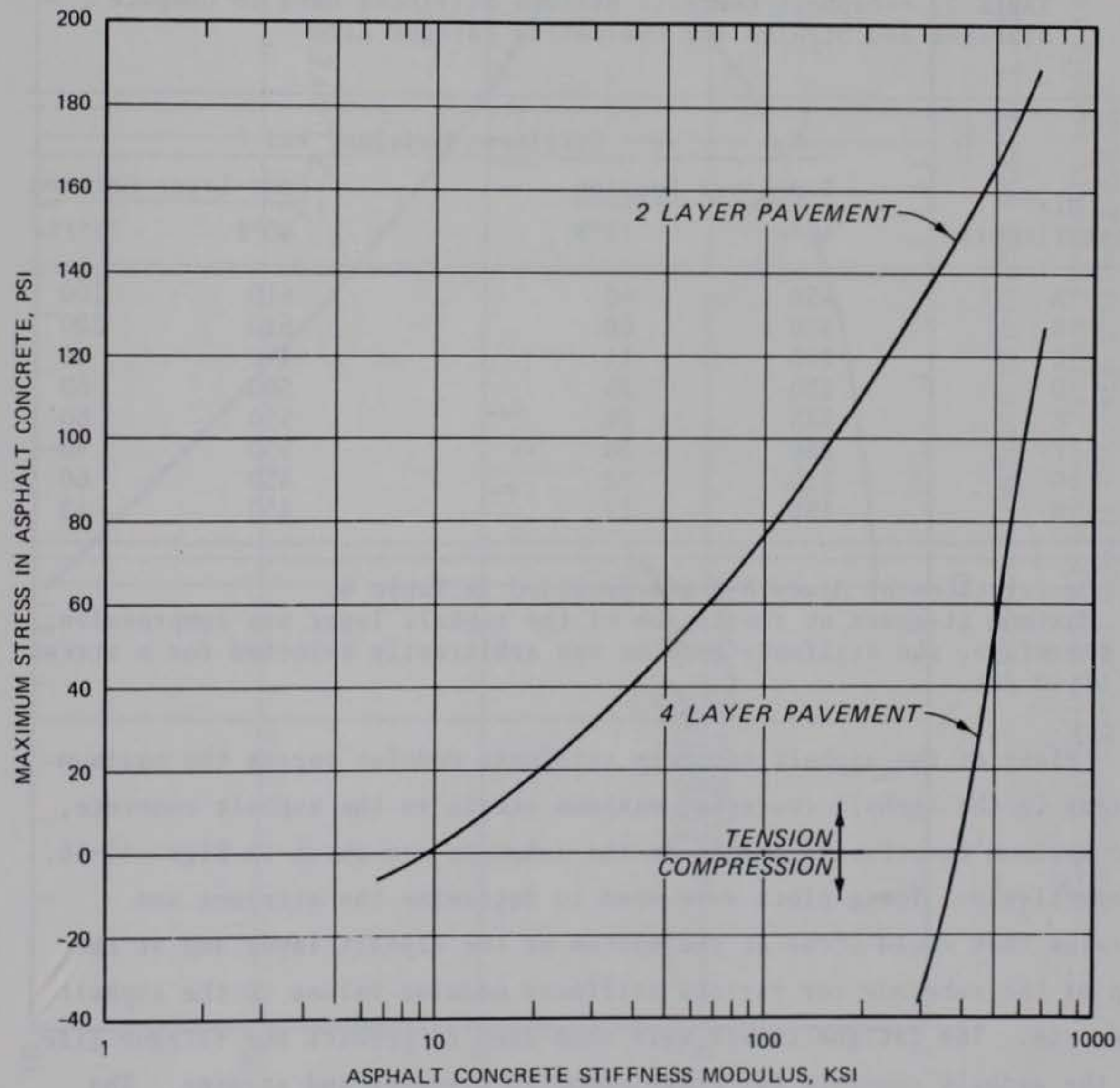

FIG. 44.--Relationship Between Maximum Stress in Asphalt Concrete Pavement Layer and Asphalt Concrete Stiffness Modulus 
section (Fig. 44), comparing stress values determined by the two methods, and modifying the estimated stiffness modulus until the stress values determined by the two methods were equal. When the stress values obtained from Figs. 36 and 44 for a given stiffness were the same, that stiffness modulus was used for computation of stresses and strains for fatigue analysis. Since the stresses in the asphalt concrete layer for the two-layer and the four-layer sections are different, the stiffness modulus of the asphalt concrete is also different. The resulting stiffness moduli used are shown in Table 27.

TABLE 27.--Asphalt Concrete Mixture Stiffness Used to Compute Stresses and Strains for Evaluating Fatigue Life

\begin{tabular}{|c|c|c|c|c|}
\hline \multirow{3}{*}{$\begin{array}{c}\text { Mix* } \\
\text { Identification }\end{array}$} & \multicolumn{4}{|c|}{ Stiffness Modulus, ksi } \\
\hline & \multicolumn{2}{|c|}{ Two-Layer Section } & \multicolumn{2}{|c|}{ Four-Layer Section } \\
\hline & $40^{\circ} \mathrm{F}$ & $77^{\circ} \mathrm{F}$ & $40^{\circ} \mathrm{F}$ & $77^{\circ} \mathrm{F} * *$ \\
\hline A & 450 & 40 & 610 & 100 \\
\hline B & 450 & 60 & 610 & 200 \\
\hline C & 200 & 11 & 450 & 9 \\
\hline D & 250 & 25 & 500 & 60 \\
\hline E & 325 & 28 & 550 & 80 \\
\hline F & 280 & 28 & 550 & 90 \\
\hline G & 210 & 32 & 450 & 60 \\
\hline $\mathrm{H}$ & 180 & 12 & 450 & 13 \\
\hline
\end{tabular}

* Descriptions of Mixes A-H are provided in Table 8.

** Maximum stresses at the bottom of the asphalt layer are compressive; therefore, the stiffness modulus was arbitrarily selected for a stress of $10 \mathrm{psi}$.

Plots of the asphalt concrete stiffness modulus versus the maximum stress in the asphalt concrete, maximum strain in the asphalt concrete, and maximum compressive stress on the subgrade are shown in Figs. 44-46, respectively. These plots were used to determine the stresses and strains that would occur at the bottom of the asphalt layer and at the top of the subgrade for various stiffness modulus values in the asphalt concrete. The fatigue curves were then used to predict the fatigue life of the asphalt concrete for these computed stresses and strains. The results for the four-layer system are shown in Table 28 .

It is significant that at $77^{\circ} \mathrm{F}$, the maximum computed radial stresses 


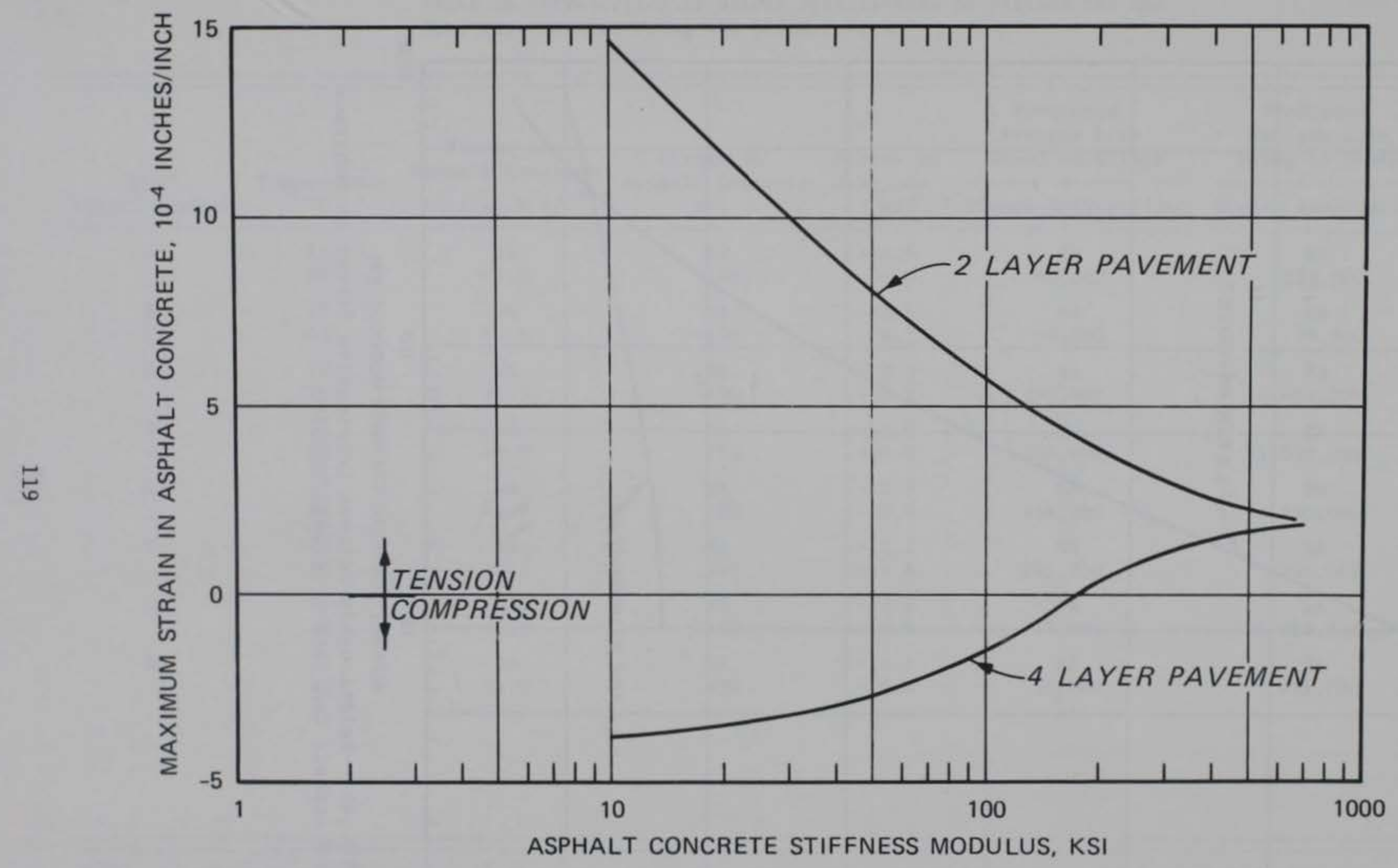

FIG. 45.--Relationship Between Maximum Strain in Asphalt Concrete

Pavement Layer and Asphalt Concrete Stiffness Modulus 


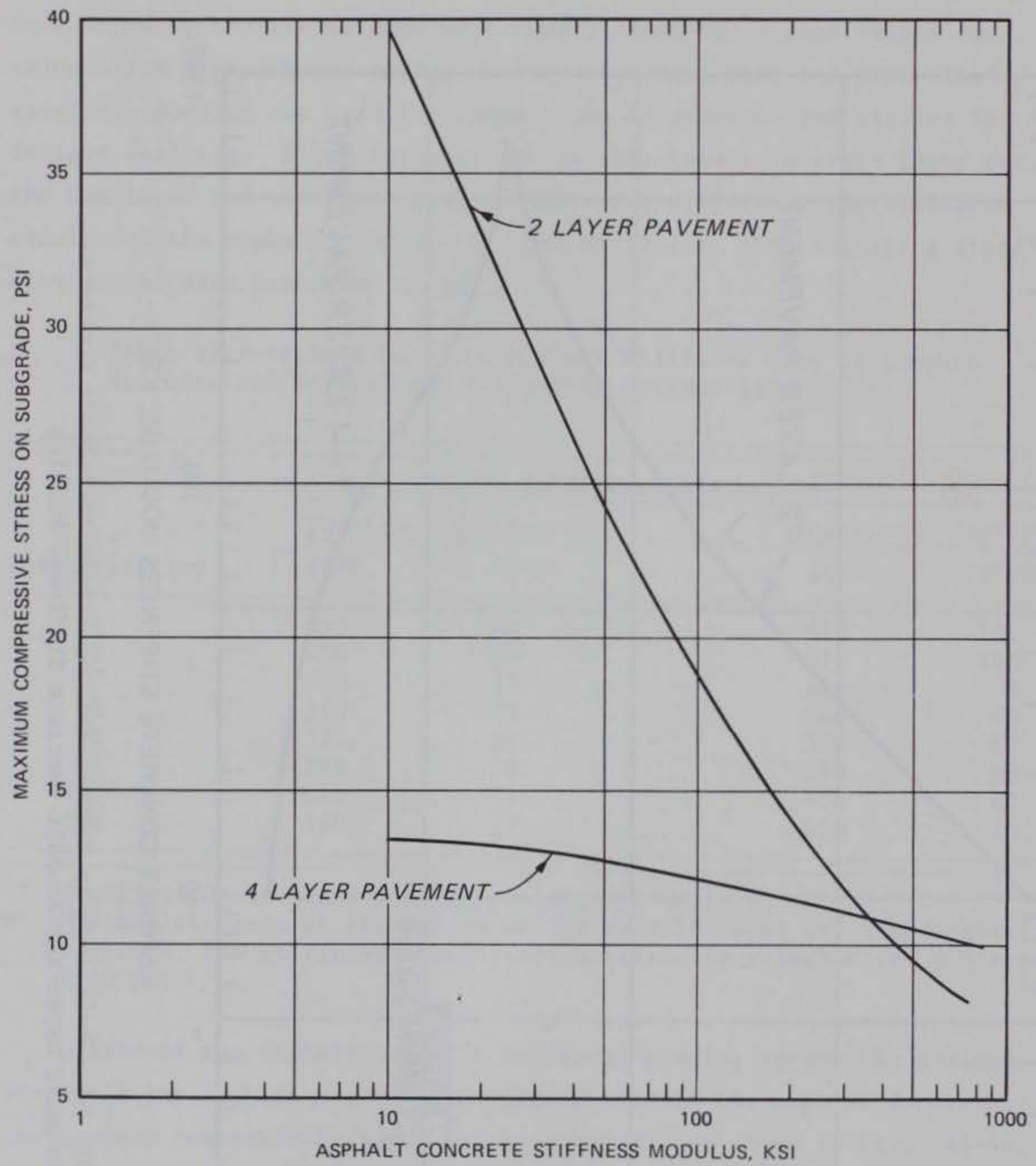

FIG. 46.--Relationship Between Compressive Stress on Subgrade and Asphalt Concrete Stiffness Modulus 
TABLE 28.--Prediction of Stress Applications to Failure for the Four-Layer System Using the BISAR Program

\begin{tabular}{|c|c|c|c|c|c|c|}
\hline & Temperature & $\begin{array}{l}\text { Stress in } \\
\text { Asphalt Concrete }\end{array}$ & $\begin{array}{c}\text { Strain in } \\
\text { Asphalt Concrete }\end{array}$ & Stress on & $\begin{array}{l}\text { Predicted } \\
\text { Fatigue Life } \\
\text { Based on Strain }\end{array}$ & $\begin{array}{c}\text { Predicted } \\
\text { Fatigue Life } \\
\text { Based on Stress }\end{array}$ \\
\hline Identification & ${ }^{\circ} \mathrm{F}$ & in./in. $\times 10^{-4}$ & psi & psi & Stress Applications & Stress Applications \\
\hline A & $\begin{array}{l}77 \\
40\end{array}$ & $\begin{array}{c}\text { NA } \\
+1.8\end{array}$ & $\begin{array}{c}\text { NA } \\
+100\end{array}$ & $\begin{array}{l}-12.6 \\
-10.3\end{array}$ & $\begin{array}{c}\text { NA } \\
98,000\end{array}$ & $\begin{array}{c}\text { NA } \\
238,000\end{array}$ \\
\hline B & $\begin{array}{l}77 \\
40\end{array}$ & $\begin{array}{c}\mathrm{NA} \\
+1.8\end{array}$ & $\begin{array}{c}\text { NA } \\
+100\end{array}$ & $\begin{array}{l}-12.1 \\
-10.3\end{array}$ & $\begin{array}{c}\text { NA } \\
64,000\end{array}$ & $\begin{array}{l}\text { NA } \\
79,000\end{array}$ \\
\hline c & $\begin{array}{l}77 \\
40\end{array}$ & $\begin{array}{c}\mathrm{NA} \\
+1.5\end{array}$ & $\begin{array}{l}\text { NA } \\
+30\end{array}$ & $\begin{array}{l}-13.3 \\
-10.9\end{array}$ & $\begin{array}{c}\text { NA } \\
191,000\end{array}$ & $\begin{array}{c}\text { NA } \\
>1,000,000\end{array}$ \\
\hline D & $\begin{array}{l}77 \\
40\end{array}$ & $\begin{array}{c}\mathrm{NA} \\
+1.6\end{array}$ & $\begin{array}{l}\text { NA } \\
+50\end{array}$ & $\begin{array}{l}-12.9 \\
-10.8\end{array}$ & $\begin{array}{c}\text { NA } \\
247,000\end{array}$ & $\begin{array}{c}\text { NA } \\
>1,000,000\end{array}$ \\
\hline E & $\begin{array}{l}77 \\
40\end{array}$ & $\begin{array}{c}\mathrm{NA} \\
+1.7\end{array}$ & $\begin{array}{l}\text { NA } \\
+80\end{array}$ & $\begin{array}{l}-12.7 \\
-10.6\end{array}$ & $\begin{array}{c}\text { NA } \\
339,000\end{array}$ & $\begin{array}{c}\text { NA } \\
530,000\end{array}$ \\
\hline $\mathbf{F}$ & $\begin{array}{l}77 \\
40\end{array}$ & $\begin{array}{c}\text { NA } \\
+1.7\end{array}$ & $\begin{array}{l}\text { NA } \\
+80\end{array}$ & $\begin{array}{l}-12.7 \\
-10.6\end{array}$ & $\begin{array}{c}\text { NA } \\
275,000\end{array}$ & $\begin{array}{c}\text { NA } \\
150,000\end{array}$ \\
\hline G & $\begin{array}{l}77 \\
40\end{array}$ & $\begin{array}{c}\text { NA } \\
+1.5\end{array}$ & $\begin{array}{l}\text { NA } \\
+30\end{array}$ & $\begin{array}{l}-12.9 \\
-10.9\end{array}$ & $\begin{array}{c}\text { NA } \\
544,000\end{array}$ & $\begin{array}{c}\text { NA } \\
>1,000,000\end{array}$ \\
\hline H & $\begin{array}{l}77 \\
40\end{array}$ & $\begin{array}{c}\text { NA } \\
+1.5\end{array}$ & $\begin{array}{l}\mathrm{NA} \\
+30\end{array}$ & $\begin{array}{l}-13.1 \\
-10.9\end{array}$ & $\begin{array}{c}\text { NA } \\
52,000\end{array}$ & $\begin{array}{c}\text { NA } \\
955,000\end{array}$ \\
\hline
\end{tabular}

NOTE: + indicates tensile stress or strain; - indicates compressive stress or strain. NA = not applicable since maximum stresses or strains are compressive.

* Descriptions of Mixes A-H are provided in Table 8 . 
and strains in the asphalt concrete for the four-layer system were compressive. This occurs because the base course is stiff in comparison to the asphalt concrete. Since the bottom of the asphalt concrete layer is never in tension, flexural fatigue is not a problem at $77^{\circ} \mathrm{F}$. Witczak observed that asphalt concrete over stiff underlying layers, such as a frozen subgrade, often does not develop tensile strains or stresses during loading (69). Flexural fatigue does become a problem at $40^{\circ} \mathrm{F}$ because the asphalt concrete becomes stiff enough with respect to the base course to cause tensile stresses and strains to exist at the bottom of the asphalt concrete.

In general, the stiffer mixtures do not perform as well in fatigue as the more flexible mixtures for the four-layer system. For this reason, the recycled mixtures generally perform as well as and in some cases better than the conventional mixtures. For instance, the predicted load applications to failure at $40^{\circ} \mathrm{F}$ for Mix C is 191,000 , compared to 98,000 for Mix A and 64,000 repetitions for Mix B. This occurs because Mixes A and $B$ are stiffer than Mix C. Mixes D, E, and F, which have predicted fatigue lives of $247,000,339,000$, and 275,000 , respectively, would provide the same magnitude of performance. The fatigue life for Mix G exceeds that for Mix E, and the fatigue life for both of these mixes exceeds that for Mix H.

Another important item in the design of a pavement structure is the stress on the subgrade. Analysis of the results indicates that stress on the subgrade ranges from 12.1 psi $\left(0.85 \mathrm{~kg} / \mathrm{cm}^{2}\right)$ for Mixes A and B to 13.3 psi $\left(0.93 \mathrm{~kg} / \mathrm{cm}^{2}\right)$ for Mixes $\mathrm{C}, \mathrm{G}$, and $\mathrm{H}$ at $77^{\circ} \mathrm{F}$. This difference in subgrade stress is small; hence, the use of more flexible mixtures should not adversely affect the compressive stress on top of the subgrade for the typical four-layer system.

Asphalt concrete mixtures for the four-layer pavement should be designed to have as much flexibility as possible provided the mixture has sufficient internal stability to support the design traffic. In general, the pavement underneath the asphalt concrete provides the structural strength for the four-layer pavement section, and the asphalt concrete is designed to provide protection to the underlying layers from wear and the intrusion of water.

Table 29 shows the results of the fatigue analysis for computed 
TABLE 29.--Prediction of Stress Applications to Failure for the Two-Layer System Using the BISAR Program

\begin{tabular}{|c|c|c|c|c|c|c|c|}
\hline \multirow{2}{*}{$\begin{array}{l}\text { Mix* } \\
\text { Identification }\end{array}$} & \multirow{2}{*}{$\begin{array}{c}\text { Temperature } \\
{ }^{\circ} \mathrm{F}\end{array}$} & \multirow{2}{*}{$\begin{array}{l}\text { Stress in } \\
\text { Asphalt Concrete } \\
\text { in./in. } \times 10^{-4}\end{array}$} & \multirow{2}{*}{$\begin{array}{c}\text { Strain in } \\
\text { Asphalt Concrete } \\
\text { psi }\end{array}$} & \multirow{2}{*}{$\begin{array}{l}\text { Stress on } \\
\text { Subgrade } \\
\text { psi }\end{array}$} & \multirow{2}{*}{$\begin{array}{c}\text { Predicted } \\
\text { Fatigue Life } \\
\text { Based on Strain } \\
\text { Stress Applications }\end{array}$} & \multicolumn{2}{|c|}{$\begin{array}{c}\text { Predicted } \\
\text { Fatigue Life } \\
\text { Based on Stress }\end{array}$} \\
\hline & & & & & & Stress & Applications \\
\hline A & $\begin{array}{l}77 \\
40\end{array}$ & $\begin{array}{l}8.8 \\
2.3\end{array}$ & $\begin{array}{r}40 \\
158\end{array}$ & $\begin{array}{l}26.5 \\
10.0\end{array}$ & $\begin{array}{r}6,100 \\
53,100\end{array}$ & & $\begin{array}{r}3,500 \\
12,900\end{array}$ \\
\hline B & $\begin{array}{l}77 \\
40\end{array}$ & $\begin{array}{l}7.4 \\
2.3\end{array}$ & $\begin{array}{r}55 \\
158\end{array}$ & $\begin{array}{l}22.5 \\
10.0\end{array}$ & $\begin{array}{r}1,500 \\
23,000\end{array}$ & & $\begin{array}{r}450 \\
3,400\end{array}$ \\
\hline C & $\begin{array}{l}77 \\
40\end{array}$ & $\begin{array}{r}13.5 \\
3.8\end{array}$ & $\begin{array}{r}4 \\
112\end{array}$ & $\begin{array}{l}38.0 \\
14.0\end{array}$ & $\begin{array}{l}1,100 \\
6,600\end{array}$ & $>1$, & $\begin{array}{r}000,000 \\
3,100\end{array}$ \\
\hline D & $\begin{array}{l}77 \\
40\end{array}$ & $\begin{array}{r}10.5 \\
3.2\end{array}$ & $\begin{array}{r}28 \\
125\end{array}$ & $\begin{array}{l}30.5 \\
12.5\end{array}$ & $\begin{array}{r}7,400 \\
29,700\end{array}$ & & $\begin{array}{l}4,800 \\
7,900\end{array}$ \\
\hline E & $\begin{array}{l}77 \\
40\end{array}$ & $\begin{array}{r}10.3 \\
2.6\end{array}$ & $\begin{array}{r}30 \\
140\end{array}$ & $\begin{array}{l}30.0 \\
12.0\end{array}$ & $\begin{array}{r}5,200 \\
80,300\end{array}$ & & $\begin{array}{r}3,300 \\
14,200\end{array}$ \\
\hline F & $\begin{array}{l}77 \\
40\end{array}$ & $\begin{array}{r}10.3 \\
3.0\end{array}$ & $\begin{array}{r}30 \\
130\end{array}$ & $\begin{array}{l}30.0 \\
12.4\end{array}$ & $\begin{array}{r}2,500 \\
44,100\end{array}$ & & $\begin{array}{l}2,000 \\
9,300\end{array}$ \\
\hline G & $\begin{array}{l}77 \\
40\end{array}$ & $\begin{array}{l}9.6 \\
3.5\end{array}$ & $\begin{array}{r}35 \\
118\end{array}$ & $\begin{array}{l}28.0 \\
13.5\end{array}$ & $\begin{array}{r}2,900 \\
18,500\end{array}$ & & $\begin{array}{l}1,900 \\
3,300\end{array}$ \\
\hline H & $\begin{array}{l}77 \\
40\end{array}$ & $\begin{array}{r}13.4 \\
4.0\end{array}$ & $\begin{array}{r}8 \\
108\end{array}$ & $\begin{array}{l}37.0 \\
15.0\end{array}$ & $\begin{array}{l}1,100 \\
2,400\end{array}$ & & $\begin{array}{r}15,200 \\
640\end{array}$ \\
\hline
\end{tabular}

* Descriptions of Mixes A-H are provided in Table 8. 
stress and strain for the two-layer system. These results indicate that $77^{\circ} \mathrm{F}$ is more critical than $40^{\circ} \mathrm{F}$ for fatigue performance for most mixes. Generally, for the two-layer pavement, the stiffer asphalt mixtures performed better in fatigue. Mix A performed better than Mixes B and C for the analysis of fatigue as a function of strain, Mix D performed better than Mixes $\mathrm{E}$ and $\mathrm{F}$, and Mix E performed better than Mixes $\mathrm{G}$ and $\mathrm{H}$. The predicted fatigue life for most of the mixtures was less than 50,000 stress applications.

A change in asphalt concrete stiffness causes the compressive stress on the subgrade to vary more for the two-layer pavement than for the four-layer system. Fig. 46 shows that the compressive stress on the subgrade is less for the four-layer system as long as the stiffness of the asphalt concrete is less than approximately 350,000 psi $\left(24,570 \mathrm{~kg} / \mathrm{cm}^{2}\right)$. In the case of the four-layer system, the stiffness of the asphalt concrete has very little effect on the stress on the subgrade; however, for the two-layer system, stress on the subgrade varies from $40 \mathrm{psi}\left(2.81 \mathrm{~kg} / \mathrm{cm}^{2}\right)$ for $E=10,000 \mathrm{psi}\left(702 \mathrm{~kg} / \mathrm{cm}^{2}\right)$ to 6 psi $\left(0.42 \mathrm{~kg} / \mathrm{cm}^{2}\right)$ for $E=700,000 \mathrm{psi}\left(49,140 \mathrm{~kg} / \mathrm{cm}^{2}\right)$.

For the four-layer pavement, the recycled mixtures generally performed equal to or better than the conventional mixtures. For the twolayer pavement, however, the conventional mixtures generally performed better than the recycled mixtures. The test results indicate that use of proper mix design techniques to obtain desired asphalt binder properties can produce recycled mixtures which will perform in a manner similar to conventional mixtures for all pavement sections. For instance, the performance of Mix D, a recycled mixture, was almost identical to Mix E, a conventional mixture, for both the two- and four-layer pavements.

A review of Fig. 45 indicates that the tensile strain in the asphalt concrete is greater in the two-layer pavement as long as the stiffness modulus is less than 700,000 psi $\left(49,140 \mathrm{~kg} / \mathrm{cm}^{2}\right)$. The stiffness modulus was measured during this study at $40^{\circ} \mathrm{F}$ and $77^{\circ} \mathrm{F}$ during the fatigue test at a load frequency of 30 cycles per minute, a load rate representative of slow-moving traffic in the field. The stiffness modulus of asphalt concrete for fast-moving traffic would be greater than that measured in this study. Based on the design example used here, deep-strength asphalt concrete would perform satisfactorily if the stiffness modulus were 
sufficiently high to prevent excessive stresses on the subgrade and to minimize the tensile strain in the asphalt mixture. Thin asphalt sections would have better fatigue performance at low values of stiffness modulus which occur at high temperatures or low rates of speed. From the standpoint of fatigue, the four-layer pavement would perform better than the two-layer system for a stiffness modulus less than 700,000 psi $\left(49,140 \mathrm{~kg} / \mathrm{cm}^{2}\right)$ and equal to the two-layer system for a stiffness modulus greater than 700,000 psi $\left(49,140 \mathrm{~kg} / \mathrm{cm}^{2}\right)$.

The results of this study indicate that fatigue of thick sections of asphalt concrete mixtures generally occurs in warmer weather, while fatigue of asphalt concrete in thin sections generally occurs in cooler weather. The work reported by Freeme and Marais showed these same conclusions (38). Properties of the asphalt binder in the recycled mixture should be selected for a particular use so that the fatigue performance is optimized. 
This research was conducted to evaluate the laboratory properties of recycled-asphalt concrete hot mix and to compare these properties with those of conventional asphalt-concrete mixtures. The data obtained from this laboratory testing program were extended by use of the BISAR computer program to predict fatigue resistance of recycled mixtures and conventional mixtures for two typical pavement sections. The results of this work led to the following conclusions:

1. Recycled mixtures performed better than conventional mixtures in fatigue when analyzed for a thin layer of asphalt concrete placed over a base course; however, the conventional mixtures performed better than the recycled mixtures when the data were analyzed for thick layers such as full-depth asphalt concrete.

2. Recycled asphalt concrete mixtures prepared with low-viscosity asphalt cement were more durable than conventional mixtures; however, recycled mixtures prepared with the recycling agent were less durable than conventional mixtures. These mixtures containing the asphalt binders which experienced the smallest weight loss and change in physical properties during artificial aging were considered to be the most durable mixtures.

3. Based on the PVN of the recovered asphalt binder, recycled mixtures prepared with the recyling agent were more susceptible to changes in temperature than recycled mixtures prepared with low-viscosity asphalt cement or conventional mixtures, Hence, the mixtures containing the recyling agent evaluated in this laboratory study would have a greater tendency to crack at lower temperatures than the recycled mixtures prepared with low-viscosity asphalt cement or the conventional mixtures.

4. The performance of mixtures, after water-conditioning, was shown to be more related to the aggregate type than type of mixture; however, the recycled mixtures prepared with the recycling agent performed better than the other mixtures when the water-sensitive aggregate was used.

5. Fatigue of asphalt mixtures can be estimated from the initial tensile strain produced by the load applied to the mixture and the asphalt penetration at the desired temperature. The model developed in this study does not take the place of laboratory flexural fatigue tests, 
but it can be used in the absence of these tests to predict fatigue life. 6. Mixture design of recycled-asphalt concrete mixtures must be carefully performed to ensure satisfactory performance of the recycled mixture. The mix design for recycled mixtures is more critical than that for conventional mixtures because the mix-design procedures not only determine the optimum asphalt content, but also indirectly determine the asphalt binder properties. Because the asphalt properties of the recycled and conventional mixtures change at different rates, tests on the recovered asphalt binder must be conducted to ensure that satisfactory asphalt binder properties are obtained in the produced mixture. 


\section{PART VIII: RECOMMENDATIONS}

Prior to this study, little laboratory work had been performed to determine and compare the properties of recycled and conventional mixtures and to extrapolate these data to predict field performance. This study has provided some insight into the expected field performance of recycled-asphalt mixtures as stated in the conclusions and has identified areas where further work is needed. Based on this study, the following recommendations are made:

1. Further work needs to be performed to develop procedures for evaluating recycling agents. Work concerning the durability and low temperature properties of recycled mixtures containing recycling agents should be performed to determine the effect of various types of recycling agents on the performance of recycled mixtures.

2. The constant-stress fatigue test, which has been shown to be more applicable to thick layers (greater than 6 inches) of asphalt concrete, was used to measure the flexural fatigue resistance of the asphalt mixtures for this study. Additional work should be performed to measure the fatigue resistance of recycled mixtures using the constant-strain mode of loading, which is more applicable to thin sections (less than 2 inches).

3. Additional work should be directed toward improved mix design procedures for recycled mixtures, and specific guidance should be developed concerning the desired properties of the combined asphalt binder.

4. Based on the results of this study, the use of a recycling agent in a recycled mixture should be minimized. A low-viscosity asphalt cement should be used as the binder in a recycled mixture when the properties of the existing binder can be properly modified with this material. When a recycling agent must be used to properly modify the existing asphalt binder, the amount used should be minimized by using a low-viscosity asphalt cement in combination with the recycling agent or by reducing the amount of RAP used in the mixture.

5. There is a need for a detailed testing program to evaluate the performance of existing recycled-asphalt concrete pavements. This evaluation should include the type of materials used in the mixture, such as recycling agent or low-viscosity asphalt cement, amount of RAP used in 
mixture, and other pertinent information. The performance could then be related to the type of materials or construction techniques used, and improvements in these areas could be made where needed. 


\section{REFERENCES}

1. American Society for Testing and Materials, "Ductility of Bituminous Materials," Designation: D 113, 1982 Annual Book of ASTM Standards, Part 15, 1982.

2. American Society for Testing and Materials, "Effect of Heat and Air on a Moving Film of Asphalt (Rolling Thin-Film Oven Test)," Designation: D 2872, 1982 Annual Book of ASTM Standards, Part 15, 1982.

3. American Society for Testing and Materials, "Kinematic Viscosity of Asphalts (Bitumens)," Designation: D 2170, 1982 Annual Book of ASTM Standards, Part 15, 1982.

4. American Society for Testing and Materials, "Penetration-Graded Asphalt Cement for Use in Pavement Construction," Designation: D 946, 1982 Annual Book of ASTM Standards, Part 15, 1982.

5. American Society for Testing and Materials, "Penetration of Bituminous Materials," Designation: D 5, 1982 Annual Book of ASTM Standards, Part 15, 1982.

6. American Society for Testing and Materials, "Quantitative Extraction of Bitumen from Bituminous Paving Mixtures," Designation: D 2172, 1982 Annual Book of ASTM Standards, Part 15, 1982.

7. American Society for Testing and Materials, "Recovery of Asphalt from Solution by Abson Method," Designation: D 1856, 1982 Annual Book of ASTM Standards, Part 15, 1982.

8. American Society for Testing and Materials, "Resistance to Deformation and Cohesion of Bituminous Mixtures by Means of Hveem Apparatus," Designation: D 1560, 1982 Annual Book of ASTM Standards, Part 15, 1982.

9. American Society for Testing and Materials, "Softening Point of Bitumen in Ethylene Glycol (Ring-and-Ball)," Designation: D 2398, 1982 Annual Book of ASTM Standards, Part 15, 1982.

10. American Society for Testing and Materials, "Specific Gravity and Absorption of Coarse Aggregate," Designation: C 127, 1982 Annual Book of ASTM Standards, Part 15, 1982.

11. American Society for Testing and Materials, "Specific Gravity and Absorption of Fine Aggregate," Designation: C 128, 1982 Annual Book of ASTM Standards, Part 15, 1982.

12. American Society for Testing and Materials, "Specific Gravity of Semi-Solid Bituminous Materials," Designation: D 70, 1982 Annual Book of ASTM Standards, Part 15, 1982.

13. American Society for Testing and Materials, "Viscosity-Graded Asphalt Cement for Use in Pavement Construction," Designation: D 3381, 1982 Annual Book of ASTM Standards, Part 15, 1982.

14. Anderson, D. A. and Dukatz, E. L., "Asphalt Properties and Composition: 1950-1980," Association of Asphalt Paving Technologists, Vol 49, Feb 1980, pp 1-29. 
15. Asphalt Institute, "Asphalt Hot-Mix Recycling," Manual Series No. 20, Aug 1981 .

16. Asphalt Institute, "Mix Design Methods for Asphalt Concrete and Other Hot Mix Types," Manual Series No. 2, Mar 1979.

17. Bonnaure, F. P. et al., "A Laboratory Investigation of the Influence of Rest Periods on the Fatigue Characteristics of Bituminous Mixtures," Proceedings of the Association of Asphalt Paving Technologists, Vol 51, 1982.

18. Brown, D. J., "Recycling Asphalt Pavements," Federal Highway Administration, FHWA-DP-39-15, Apr 1979.

19. Brown, E. R., "Evaluation of Asphaltic Concrete Pavements Subjected to T-38 Aircraft Loadings," Master's thesis, Mississippi State University, Dec 1974.

20. Brown, E. R., "Hot Mix Recycling at Pope AFB," paper presented at New Mexico Paving Conference, Albuquerque, N. Mex., Jan 1981.

21. Brown, E. R., "Insuring Quality in Hot Mix Recycling," paper presented at Transportation Research Board Annual Meeting, Washington, D. C., Jan 1982 .

22. Brown, E. R., "Recycled Materials--Applications to Air Force Pavements," Miscellaneous Paper GL-80-14, U. S. Army Engineer Waterways Experiment Station, Sep 1980.

23. Brown, S. F. and Pell, P. S., "A Fundamental Structural Design Procedure for Flexible Pavements," Proceedings, 3rd International Conference on Structural Design of Asphalt Pavements, London, Vol 1, 1972, pp 369-381.

24. Deacon, J. A., "Fatigue of Asphalt Concrete," Graduate Report, ITT, University of California, Berkeley, 1965.

25. Department of Defense, "Test Methods for Bituminous Paving Materials," MIL-STD-620A.

26. Department of the Army, "Bituminous Pavements Standard Practice," TM 5-822-8, Dec 1972 .

27. Department of the Army, "Effects of Traffic with Small High-Pressure Tires on Asphalt Pavements," TM 3-314, Jun 1950.

28. Department of the Army, "Investigation of the Design and Control of Asphalt Paving Mixtures," TM 3-254, 3 volumes, May 1948.

29. Department of the Army, "Selecting and Specifying Asphalt Cements," Engineering Technical Letter, 13 Jan 1976.

30. Departments of the Navy, Army, and Air Force, "Flexible Pavement Design for Airfields," TM 5-825-2, Aug 1978.

31. Dumler, J. and Beecroft, G., "Recycling Asphalt Pavements--Woodburn, Oregon," Federal Highway Administration, FHWA-DP-39-4, Mar 1979.

32. Dunning, R. L. and Mendenhal1, R. L., "Design of Recycled Asphalt Pavements and Selection of Modifiers," Recycling of Bituminous Pavements, L. E. Wood, Ed., American Society for Testing and Materials, 1978 , pp $35-46$. 
33. Epps, J. A. and Monismith, C. L., "Fatigue of Asphalt Concrete Mixtures--Summary of Existing Information," Fatigue of Compacted Bituminous Aggregate Mixtures, American Society for Testing and Materials, STP 508, 1972, pp 19-45.

34. Epps, J. A. and Monismith, C. L., "Influence of Mixture Variables on the Flexural Fatigue Properties of Asphalt Concrete," Association of Asphalt Paving Technologists, Vol 38, pp 423-464, Feb 1969.

35. Epps, J. A. et al., "Mixture Properties of Recycled Central Plant Materials," American Society for Testing and Materials, STP 662, Dec 1977, pp 68-103.

36. Francken, L., "Fatigue d'un Enrobe' Bitumineux Soumix a' des Conditions de Sollicitations Re'alistes," la Technique Routie're 4, 1979.

37. Francken, L. and Verstraeten, J., "Methods for Predicting Moduli and Fatigue Laws of Bituminous Road Mixes Under Repeated Bending," paper presented at the 53rd Meeting of the Highway Research Board.

38. Freeme, C. R. and Marais, C. P., "Thin Bituminous Surfaces: Their Fatigue Behavior and Prediction," Structural Design of Asphalt Concrete Pavements to Prevent Fatigue Cracking, Special Report 140, Highway Research Board, Washington, D. C., 1973.

39. Gaw, W. J., "Measurement and Prediction of Asphalt Stiffnesses and Their Use in Developing Specifications to Control Low-Temperature Pavement Transverse Cracking," American Society for Testing and Materials, STP 628, pp 57-67, Jul 1976.

40. Henely, R. P., "Recycling Asphalt Pavements--Kossuth County, Iowa," Federal Highway Administration, FHWA-DP-39-10, Feb 1979.

41. Hughes, C. S., "Recycling Asphalt Pavements--Chester, Virginia," Federal Highway Administration, FHWA-DP-39-14, Feb 1979.

42. Ingberg, R. C. et al., "Minnesota Heat Transfer Method for Recycling Bituminous Pavement," Minnesota Department of Transportation Investigation, Report No. 646, 1977.

43. Jimenez, R. A., "Fatigue Testing of Asphaltic Concrete Slabs," Fatigue of Compacted Bituminous Aggregate Mixtures, American Society For Testing and Materials, STP 508, 1972, pp 3-17.

44. Kallas, B. F. and Puzinauskas, V. P., "Flexural Fatigue Tests on Asphalt Paving Mixtures," Fatigue of Compacted Bituminous Aggregate Mixtures, American Society for Testing and Materials, STP 508, 1972, pp 47-65.

45. Kandhal, P., "Low-Temperature Ductility in Relation to Pavement Performance," American Society for Testing and Materials, STP 628, Jul 1976, pp 95-106.

46. Kandhal, P. S. and Wenger, M. E., "Asphalt Properties in Relation to Pavement Performance," Asphalt Properties and Performance, Transportation Research Record 544, 1975.

47. Kemp, G. R. and Predoeh1, N. H., "A Comparison of Field and Laboratory Environments on Asphalt Durability," Association of Asphalt Paving Technologists, Vol 50, pp 492-537, Feb 1981. 
48. LeClerc, R. V. et al., "Recycling Asphalt Pavements--Ellensburg, Washington," Federal Highway Administration, FHWA-DP-39-3, Aug 1978.

49. Little, D. N. and Epps, J. A., "Evaluation of Certain Structural Characteristics of Recycled Pavement Materials," Proceedings of the Association of Asphalt Paving Technologists, Vol 49, 1980, pp 219-251.

50. Little, D. N. et al., "Effect of Recycling Agents on the Structural Performance of Recycled Asphalt Concrete Materials," Association of Asphalt Paving Technologists, Vol 50, Feb 1981, pp 32-63.

51. Lottman, R. P., "Predicting Moisture-Induced Damage to Asphaltic Concrete," National Cooperative Highway Research Program Report 192 , 1978.

52. Majidzadeh, Kamran et al., "Analysis of Fatigue of Paving Mixtures From the Fracture Mechanics Viewpoint," Fatigue of Compacted Bituminous Aggregate Mixtures, ASTM STP 508, American Society of Testing and Materials, 1972, pp. 67-83.

53. Maupin, G. W., Jr., "Results of Indirect Tensile Tests Related to Asphalt Fatigue," Highway Research Record No. 404, Asphalt Mixture Characterization and Asphalt Grading, 1972, pp 1-7.

54. McLeod, N. W., "A Rational Basis for Specifications for Paving Asphalts," paper presented at the Annual Conference of the Canadian Technical Asphalt Association, Montreal, Quebec, Nov 1981.

55. Miner, M. A., "Cumulative Damage in Fatigue," Journal of Applied Mechanics, 1945.

56. Monismith, C. L. et al., "Asphalt Mixture Behavior in Repeated Flexure," Report No. TE 70-5, University of California, Berkeley, Dec 1970 .

57. Ott, L., An Introduction to Statistical Methods and Data Analysis, Wadsworth Publishing Company, Belmont, Calif., 1977.

58. Parker, F., Jr. et al., "Development of a Structural Design Procedure for Rigid Airport Pavements," Technical Report GL-79-4, U. S. Army Engineer Waterways Experiment Station, Apr 1979.

59. Pell, P. S., "Characterization of Fatigue Behavior," Structural Design of Asphalt Concrete Pavements to Prevent Fatigue Cracking, Highway Research Board, Special Report 140, 1973, pp 49-64.

60. Pell, P. S., "Fatigue of Bituminous Materials in Flexible Pavements," Proceedings, The Institute of Civil Engineers, Vol 31, Jul 1965 .

61. Pell, P. S. and Taylor, I. F., "Asphaltic Road Materials in Fatigue," Association of Asphalt Paving Technologists, Vol 38, pp 371-422, Feb 1969.

62. Proudy, H. et al., "Recycled Asphalt Concrete," Federal Highway Administration, Implementation Package 75-5, Sep 1975. 
63. Puzinauskas, V. P., "Properties of Asphalt Cements," The Asphalt Institute, Research Report No. 80-2, Nov 1980.

64. Rostler, F. S., "Prediction of Performance Based on Asphalt Composition Using Precipitation Methods," Proceedings, Highway Conference on Research and Development of Quality Control and Acceptance Specifications, U. S. Department of Commerce, Bureau of Public Roads, Vol 2, pp 93-158, Apr 1965.

65. Schmidt, R. J., "A Practical Method for Determining the Resilient Modulus of Asphalt-Treated Mixes," Highway Research Record No. 404, Highway Research Board, 1972.

66. Terrel, R. L. and Fritchen, D. R., "Laboratory Performance of Recyled Asphalt Concrete," American Society for Testing and Materials, STP 662, Dec 1977, pp 104-122.

67. Vallerga, B. A., "Introduction--Pavement Deficiencies Related to Asphalt Durability," Symposium on Asphalt Durability, Association of Asphalt Paving Technologists, Vol 50, pp 481-491, Feb 1981.

68. Whitcomb, W. G. et al., "Evaluation of a Unified Design for Asphalt Recycling by Means of Dynamic and Fatigue Testing," Association of Asphalt Paving Technologists, Vol 50, pp 1-31, Feb 1981.

69. Witczak, M. W., "Fatigue Subsystem Solution for Asphalt Concrete Airfield Pavements," Structural Design of Asphalt Concrete Pavements to Prevent Fatigue Cracking, Special Report 140, Highway Research Board, Washington, D. C., 1973.

70. Wyoming State Highway Department, "Recycling Asphalt Pavements-Laramie, Wyoming," Federal Highway Administration, FHWA-DP-39-9, Feb 1979.

71. Yoder, E. J. and Witczak, M. W., Principles of Pavement Design, John Wiley \& Sons, New York, 1975. 
APPENDIX A: DATA FROM FATIGUE TESTS

\begin{tabular}{|c|c|c|c|c|c|}
\hline Mixture & $\underline{\text { Temperature, }}{ }^{\circ} \mathrm{F}$ & $\begin{array}{c}\text { Stress } \\
\text { psi }\end{array}$ & $\begin{array}{c}\text { Initial } \\
\text { Strain } \\
\text { Inches/Inch } \\
\end{array}$ & $\begin{array}{c}\text { Stiffness } \\
\text { Modulus } \\
\text { psi }\end{array}$ & $\begin{array}{c}\text { Cycles } \\
\text { to } \\
\text { Failure }\end{array}$ \\
\hline A & 77 & $\begin{array}{l}23.1 \\
17.8 \\
19.8 \\
22.9 \\
53.3 \\
60.4 \\
44.0 \\
31.6 \\
22.0 \\
37.8\end{array}$ & $\begin{array}{l}0.00071 \\
0.00029 \\
0.00038 \\
0.00042 \\
0.00143 \\
0.00217 \\
0.00135 \\
0.00067 \\
0.00030 \\
0.00089\end{array}$ & $\begin{array}{l}32,535 \\
61,379 \\
52,105 \\
54,524 \\
37,273 \\
27,834 \\
32,593 \\
47,164 \\
73,333 \\
42,472\end{array}$ & $\begin{array}{r}13,876 \\
177,400 \\
130,445 \\
30,951 \\
1,178 \\
496 \\
1,806 \\
11,862 \\
79,742 \\
6,101\end{array}$ \\
\hline & 40 & $\begin{array}{l}186.6 \\
177.8 \\
190.0 \\
164.4 \\
106.7 \\
133.3 \\
147.8 \\
155.5 \\
191.1 \\
204.4 \\
102.2\end{array}$ & $\begin{array}{l}0.00062 \\
0.00043 \\
0.00043 \\
0.00038 \\
0.00014 \\
0.00019 \\
0.00043 \\
0.00029 \\
0.00047 \\
0.00113 \\
0.00038\end{array}$ & $\begin{array}{l}300,968 \\
413,488 \\
441,860 \\
432,632 \\
762,143 \\
701,579 \\
343,721 \\
536,207 \\
406,596 \\
180,885 \\
268,947\end{array}$ & $\begin{array}{r}3,265 \\
3,345 \\
6,302 \\
13,917 \\
175,483 \\
41,971 \\
29,870 \\
26,205 \\
8,094 \\
755 \\
107,605\end{array}$ \\
\hline B & 77 & $\begin{array}{l}40.9 \\
21.3 \\
35.6 \\
32.0 \\
26.7 \\
24.9 \\
39.1 \\
40.9 \\
32.9 \\
44.4 \\
40.0\end{array}$ & $\begin{array}{l}0.00054 \\
0.00018 \\
0.00042 \\
0.00030 \\
0.00030 \\
0.00024 \\
0.00047 \\
0.00047 \\
0.00036 \\
0.00097 \\
0.00066\end{array}$ & $\begin{array}{r}75,740 \\
118,333 \\
84,761 \\
106,667 \\
89,000 \\
103,750 \\
83,191 \\
87,021 \\
91,389 \\
45,773 \\
60,606\end{array}$ & $\begin{array}{r}820 \\
113,677 \\
9,150 \\
17,272 \\
33,725 \\
80,085 \\
8,068 \\
6,286 \\
10,340 \\
1,058 \\
2,911\end{array}$ \\
\hline & 40 & $\begin{array}{r}106.7 \\
151.1 \\
128.9 \\
88.9 \\
97.8 \\
91.1 \\
173.3 \\
188.9 \\
160.0 \\
168.9 \\
140.4\end{array}$ & $\begin{array}{l}0.00019 \\
0.00034 \\
0.00024 \\
0.00014 \\
0.00015 \\
0.00015 \\
0.00043 \\
0.00047 \\
0.00029 \\
0.00047 \\
0.00035\end{array}$ & $\begin{array}{l}561,579 \\
444,412 \\
537,083 \\
635,000 \\
652,000 \\
607,333 \\
403,023 \\
401,915 \\
551,724 \\
359,362 \\
401,143\end{array}$ & $\begin{array}{r}60,566 \\
15,820 \\
32,739 \\
202,312 \\
77,462 \\
145,131 \\
2,266 \\
953 \\
6,579 \\
1,090 \\
761\end{array}$ \\
\hline
\end{tabular}




\begin{tabular}{|c|c|c|c|c|c|}
\hline Mixture & Temperature, ${ }^{\circ} \mathrm{F}$ & $\begin{array}{c}\text { Stress } \\
\text { psi }\end{array}$ & $\begin{array}{c}\text { Initial } \\
\text { Strain } \\
\text { Inches/Inch } \\
\end{array}$ & $\begin{array}{c}\text { Stiffness } \\
\text { Modulus } \\
\text { psi }\end{array}$ & $\begin{array}{l}\text { Cycles } \\
\text { to } \\
\text { Failure }\end{array}$ \\
\hline \multirow[t]{20}{*}{ C } & 77 & 8.9 & 0.00094 & 9,500 & 4,350 \\
\hline & & 5.3 & 0.00048 & 11,000 & 148,752 \\
\hline & & 7.1 & 0.00047 & 15,100 & 137,050 \\
\hline & & 9.8 & 0.00075 & 13,100 & 27,734 \\
\hline & & 11.6 & 0.00283 & 4,100 & 90 \\
\hline & & 10.7 & 0.00208 & 5,100 & 135 \\
\hline & & 8.4 & 0.00053 & 15,800 & 21,311 \\
\hline & & 7.6 & 0.00047 & 16,200 & 67,580 \\
\hline & & 10.2 & 0.00054 & 18,900 & 3,840 \\
\hline & & 11.1 & 0.00159 & 7,000 & 656 \\
\hline & 40 & 111.1 & 0.00033 & 336,700 & 22,877 \\
\hline & & 75.5 & 0.00019 & 397,400 & 63,573 \\
\hline & & 128.9 & 0.00078 & 165,300 & 650 \\
\hline & & 42.7 & 0.00017 & 251,200 & 240,000 \\
\hline & & 97.8 & 0.00033 & 296,400 & 14,259 \\
\hline & & 120.0 & 0.00072 & 166,700 & 906 \\
\hline & & 78.2 & 0.00025 & 312,800 & 21,173 \\
\hline & & 55.1 & 0.00019 & 290,000 & 116,195 \\
\hline & & 79.1 & 0.00037 & 213,800 & 2,882 \\
\hline & & 67.1 & 0.00033 & 203,300 & 5,433 \\
\hline \multirow[t]{22}{*}{ D } & 77 & 60.0 & 0.00635 & 9,449 & 218 \\
\hline & & 41.8 & 0.00280 & 14,929 & 975 \\
\hline & & 21.8 & 0.00081 & 26,914 & 17,327 \\
\hline & & 17.8 & 0.00058 & 30,690 & 64,359 \\
\hline & & 26.7 & 0.00101 & 26,436 & 8,394 \\
\hline & & 16.0 & 0.00040 & 40,000 & 53,184 \\
\hline & & 12.4 & 0.00034 & 36,471 & 104,250 \\
\hline & & 19.6 & 0.00066 & 29,697 & 8,962 \\
\hline & & 19.1 & 0.00048 & 39,792 & 10,680 \\
\hline & & 35.3 & 0.00208 & 16,971 & 1,390 \\
\hline & & 33.3 & 0.00192 & 17,344 & 2,432 \\
\hline & 40 & 153.3 & 0.00070 & 219,000 & 3,152 \\
\hline & & 128.9 & 0.00047 & 274,255 & 8,774 \\
\hline & & 106.7 & 0.00031 & 344,194 & 26,332 \\
\hline & & 88.9 & 0.00030 & 296,333 & 59,800 \\
\hline & & 117.8 & 0.00048 & 245,417 & 9,667 \\
\hline & & 66.7 & 0.00017 & 392,353 & 249,000 \\
\hline & & 173.3 & 0.00106 & 163,491 & 988 \\
\hline & & 80.0 & 0.00029 & 275,862 & 90,546 \\
\hline & & 113.3 & 0.00037 & 306,216 & 9,142 \\
\hline & & 164.4 & 0.00093 & 176,774 & 1,409 \\
\hline & & 141.3 & 0.00042 & 336,429 & 6,113 \\
\hline
\end{tabular}




\begin{tabular}{|c|c|c|c|c|c|}
\hline Mixture & Temperature, ${ }^{\circ} \mathrm{F}$ & $\begin{array}{l}\text { Stress } \\
\text { psi }\end{array}$ & $\begin{array}{c}\text { Initial } \\
\text { Strain } \\
\text { Inches/Inch }\end{array}$ & $\begin{array}{l}\text { Stiffness } \\
\text { Modulus } \\
\text { psi }\end{array}$ & $\begin{array}{c}\text { Cycles } \\
\text { to } \\
\text { Failure }\end{array}$ \\
\hline E & 77 & $\begin{array}{l}21.8 \\
22.2 \\
30.2 \\
15.3 \\
14.0 \\
12.7 \\
16.4 \\
10.7 \\
33.8 \\
23.3\end{array}$ & $\begin{array}{l}0.00084 \\
0.00059 \\
0.00117 \\
0.00037 \\
0.00027 \\
0.00020 \\
0.00030 \\
0.00069 \\
0.00162 \\
0.00097\end{array}$ & $\begin{array}{l}25,952 \\
37,627 \\
25,812 \\
41,351 \\
51,852 \\
63,500 \\
54,667 \\
15,507 \\
20,864 \\
24,021\end{array}$ & $\begin{array}{r}4,710 \\
7,620 \\
2,820 \\
78,300 \\
56,254 \\
260,277 \\
83,429 \\
35,135 \\
2,719 \\
6,550\end{array}$ \\
\hline & 40 & $\begin{array}{r}129.8 \\
120.0 \\
164.4 \\
97.8 \\
106.7 \\
151.1 \\
175.5 \\
164.4 \\
186.6 \\
112.0\end{array}$ & $\begin{array}{l}0.00039 \\
0.00032 \\
0.00047 \\
0.00021 \\
0.00032 \\
0.00055 \\
0.00081 \\
0.00040 \\
0.00074 \\
0.00028\end{array}$ & $\begin{array}{l}332,821 \\
375,000 \\
349,787 \\
465,714 \\
333,438 \\
274,727 \\
216,667 \\
411,000 \\
252,162 \\
400,000\end{array}$ & $\begin{array}{r}20,461 \\
30,501 \\
10,493 \\
113,247 \\
83,394 \\
8,000 \\
1,632 \\
5,730 \\
2,400 \\
109,546\end{array}$ \\
\hline F & 77 & $\begin{array}{l}21.6 \\
32.4 \\
16.0 \\
14.0 \\
18.2 \\
12.7 \\
20.0 \\
24.0 \\
26.7\end{array}$ & $\begin{array}{l}0.00060 \\
0.00158 \\
0.00029 \\
0.00029 \\
0.00038 \\
0.00029 \\
0.00068 \\
0.00063 \\
0.00061\end{array}$ & $\begin{array}{l}36,000 \\
20,506 \\
55,172 \\
48,276 \\
47,895 \\
43,793 \\
29,412 \\
38,095 \\
43,770\end{array}$ & $\begin{array}{r}21,180 \\
1,133 \\
50,048 \\
78,350 \\
20,219 \\
145,080 \\
6,455 \\
10,397 \\
2,624\end{array}$ \\
\hline & 40 & $\begin{array}{r}133.3 \\
142.2 \\
164.4 \\
175.5 \\
111.1 \\
97.8 \\
122.2 \\
186.6 \\
120.0 \\
102.2 \\
96.0\end{array}$ & $\begin{array}{l}0.00086 \\
0.00049 \\
0.00063 \\
0.00073 \\
0.00047 \\
0.00024 \\
0.00043 \\
0.00069 \\
0.00052 \\
0.00030 \\
0.00020\end{array}$ & $\begin{array}{l}155,000 \\
290,204 \\
260,952 \\
240,411 \\
236,383 \\
407,500 \\
284,186 \\
270,435 \\
230,769 \\
340,667 \\
480,000\end{array}$ & $\begin{array}{r}2,618 \\
9,411 \\
3,741 \\
1,591 \\
8,400 \\
95,949 \\
10,046 \\
1,680 \\
7,491 \\
37,211 \\
149,100\end{array}$ \\
\hline
\end{tabular}




\begin{tabular}{|c|c|c|c|c|c|}
\hline Mixture & Temperature, ${ }^{\circ} \mathrm{F}$ & $\begin{array}{l}\text { Stress } \\
\text { psi }\end{array}$ & $\begin{array}{c}\text { Initial } \\
\text { Strain } \\
\text { Inches/Inch } \\
\end{array}$ & $\begin{array}{c}\text { Stiffness } \\
\text { Modulus } \\
\text { psi } \\
\end{array}$ & $\begin{array}{c}\text { Cycles } \\
\text { to } \\
\text { Failure }\end{array}$ \\
\hline G & 77 & $\begin{array}{l}43.3 \\
34.4 \\
22.0 \\
17.8 \\
30.0 \\
16.7 \\
19.8 \\
14.9 \\
13.8 \\
15.6\end{array}$ & $\begin{array}{l}0.00152 \\
0.00094 \\
0.00063 \\
0.00048 \\
0.00095 \\
0.00036 \\
0.00071 \\
0.00043 \\
0.00029 \\
0.00033\end{array}$ & $\begin{array}{l}24,487 \\
36,596 \\
34,921 \\
37,083 \\
31,579 \\
46,389 \\
27,887 \\
34,651 \\
47,586 \\
47,273\end{array}$ & $\begin{array}{r}998 \\
2,808 \\
8,250 \\
16,558 \\
2,472 \\
64,198 \\
8,460 \\
27,928 \\
94,024 \\
68,049\end{array}$ \\
\hline & 40 & $\begin{array}{r}151.5 \\
129.8 \\
109.3 \\
120.0 \\
97.8 \\
86.7 \\
66.4 \\
77.5 \\
57.8\end{array}$ & $\begin{array}{l}0.00085 \\
0.00067 \\
0.00042 \\
0.00048 \\
0.00039 \\
0.00035 \\
0.00030 \\
0.00028 \\
0.00023\end{array}$ & $\begin{array}{l}178,235 \\
193,731 \\
260,238 \\
250,000 \\
250,769 \\
247,714 \\
221,333 \\
276,786 \\
251,304\end{array}$ & $\begin{array}{r}675 \\
1,093 \\
11,680 \\
4,244 \\
7,263 \\
17,469 \\
45,166 \\
43,466 \\
93,982\end{array}$ \\
\hline H & 77 & $\begin{array}{r}20.0 \\
10.7 \\
8.2 \\
6.7 \\
5.1 \\
5.8 \\
5.6 \\
6.7 \\
7.1 \\
8.4 \\
8.2 \\
6.7\end{array}$ & $\begin{array}{l}0.00240 \\
0.00122 \\
0.00036 \\
0.00039 \\
0.00019 \\
0.00032 \\
0.00024 \\
0.00039 \\
0.00032 \\
0.00047 \\
0.00036 \\
0.00039\end{array}$ & $\begin{array}{r}8,333 \\
8,770 \\
22,778 \\
17,179 \\
26,842 \\
18,125 \\
23,333 \\
17,179 \\
22,188 \\
17,872 \\
22,778 \\
17,179\end{array}$ & $\begin{array}{r}330 \\
1,065 \\
17,862 \\
28,290 \\
285,602 \\
38,135 \\
28,459 \\
39,930 \\
40,955 \\
5,300 \\
136,192 \\
19,485\end{array}$ \\
\hline & 40 & $\begin{array}{r}106.2 \\
75.5 \\
54.0 \\
66.7 \\
50.0 \\
88.9 \\
46.7 \\
95.5 \\
102.2 \\
46.7\end{array}$ & $\begin{array}{l}0.00094 \\
0.00028 \\
0.00020 \\
0.00029 \\
0.00019 \\
0.00036 \\
0.00012 \\
0.00035 \\
0.00040 \\
0.00015\end{array}$ & $\begin{array}{l}112,979 \\
269,643 \\
270,000 \\
230,000 \\
263,158 \\
246,944 \\
389,167 \\
272,857 \\
255,500 \\
311,333\end{array}$ & $\begin{array}{r}391 \\
7,597 \\
42,166 \\
6,150 \\
50,647 \\
2,625 \\
110,296 \\
3,118 \\
536 \\
42,955\end{array}$ \\
\hline
\end{tabular}

